CIHM

Microfiche

Series

(Monographs)
ICMH

Collection de microfiches (monographies)
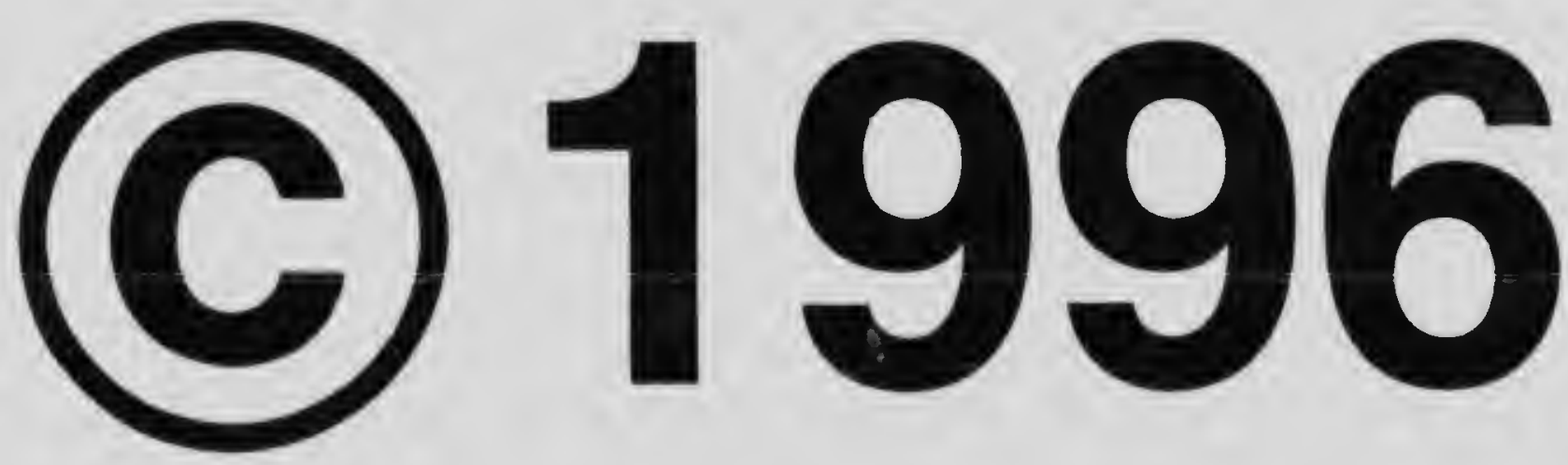
Technical and Bibliographic Notes / Notes techniques et biblıographiques

The Institure has attempted to obtain the best original copy avalable for filming. Features of this copy which may be bibliographically unique, which may alter any of the images in the reproduction, or which may significantly change the usuai method of filming, are checked below.

Coloured covers/

Couverture de couleur

Covers damaged/

Couverture endommagé

Couverture restaurée et/ou pelliculée

Cover title missing/

Le titre de couverture manque

Coloured maps/

Cal tes géographiques en coulesr

Coloured irik (i.e. other than blue or black)/

Encre de couleur (i.e. autre que bleue ou noire)

Planches et/ou illustrations en couleur

Bound with other material/

Relié avec d'autres documents

Tight bonding may cause shadows of distortion along interıor margin/

La reliure serrée peut causer de l'ombre ou de la distorsion le long de la marge intérieure within the text. Whenever possible, these have been omitied from filmıng/

II se peut que certaines pages blanches ajouttes lors d'une restauration apparaissent dans le texte. mais, lorsque cela était possible, ces pages $n$ 'ont pas ète filmées.

Additional comments /

Coinmentaires supplèmentaires:
Covers res tored and/or laminated/

Coloured plates and/or Illustrations/

Blank leaves added during restoration may appear

L'Institut a microfilmé le meilleur exemplaire qu'il lui a été possible de se procurer. Les détails de cet exemplaire qui sont peut-étre uniques du point de vue bibliographique, qui peuvent modifier une image reproduite, ou qui peuvent exiger une modification dans la méthode normale de filmage sont indiqués ci-dessous.

Coloured pages/

Pages de couleur

Pages damaged/

Pages endommagées

Pages restored and/or lammatec

Pages restaurées et/ou pelliculét.

Pages discoloured. stained or foxed:

Pages décolorées, tachetées ou piqué.

Pages detached/

Pages détachíes

Showthrough/

Transparence

Quality of print varies/

Qualıte ınégale de l'impressıon

Contınuous pagination/

Pagination contınue

$\checkmark$ Includes index(es)/

Comprend un (des) index

Title on header taken from: /

Le titre de l'en téte provient

7 Title page of issuel

Page de tire de la livraison

Caption of issuel

Titre de depart de la liviaison

Masthead/

Gènérique (pérıodiques) de la liviaison

Wrinkled pages may f1lm slightly out of focus.

This item is filmed at the reduction ratio checked below/

Ce document est filmé au taux de réduction indiqué $\mathrm{cl}$ dessous

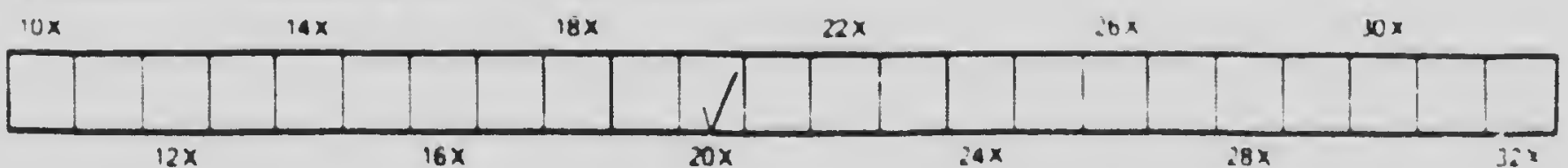


The copy fllmed here hes been reproduced thenks to the generoslty of:

Canadiana department

North York Central Library

The Imeges appesing hore are the best quellty posslble considerlng the condltion and legibillty of the orlginal copy and In keeping with the filming contract specifleatlons.

Original coples in prined peper covers are flimed beginning with the front cover and anding on the last page with a printed or illustrated impres. slon, or the beck cover when approprlate. Ali other orlolnal copies are filmed beglnning on the flrst page with a printed or lllustrated Impres. slon, and ending on the last page with e printed or lllustreted Impression.

The lest recorded frome on each mlcroflche shall conteln the symbol $\longrightarrow$ Imeening "CON. TINUED"I, or the symbol 7 (meening "END"). whlchover epplles.

Maps, pletes, charis, otc., mey be fllmed st diffarent reduction ratlos. Those 100 large to be entiraly Included in one sxposure are filmed beginning in the upper loft hend cornor, loft to rloht and top to bottom. as many frames ss requirad. The following dlegrems illustrete the mothod:
L'exemplaire filmb fut reproduit grâce la la oénórositó de:

Canadiana department

North York Central Library

Les images sulvantes ont bto reproduites avec le plus grand soin, compte tenu de la condition ot de la nettete de l'exemplaire flimb. ot en conformltb avec las conditlons du contrat de fllmage.

Lee exemplalres originaux dont la couverture on papler est Imprimbe sont filmb́s en commencant par le premier plat ot en terminant soit par la dernidre page qui comporte une empreinte d'Impression ou d'illustration, soit par le second zlat, selon le cas. Tous les autres exemplaires orlginaux sont filmbe en commencant par la premlore page qui compore une empreinte d'impression ou d'lllustratlon et en terminant par la derniere page qul comporte une telle empreinte.

Un des symboles suivants apparaitra sur la dernidre image de cheque microfiche, selon le sas: lo symbole signlfie "A SUIVRE", lo symbole 7 signifie "FIN".

Les cartes, planches, tableaux, etc., pouvent etre filmós des toux de róduction differents. Lorsque le document est trop grand pour btre reproduit en un soul clicho. II est filmb a partir de l'angle supbrleur gauche, de gauche droite, et de haut on bas. on prenant le nombre d'Images nccessaire. Les dlagrammes suivants Illustrent la mothode.
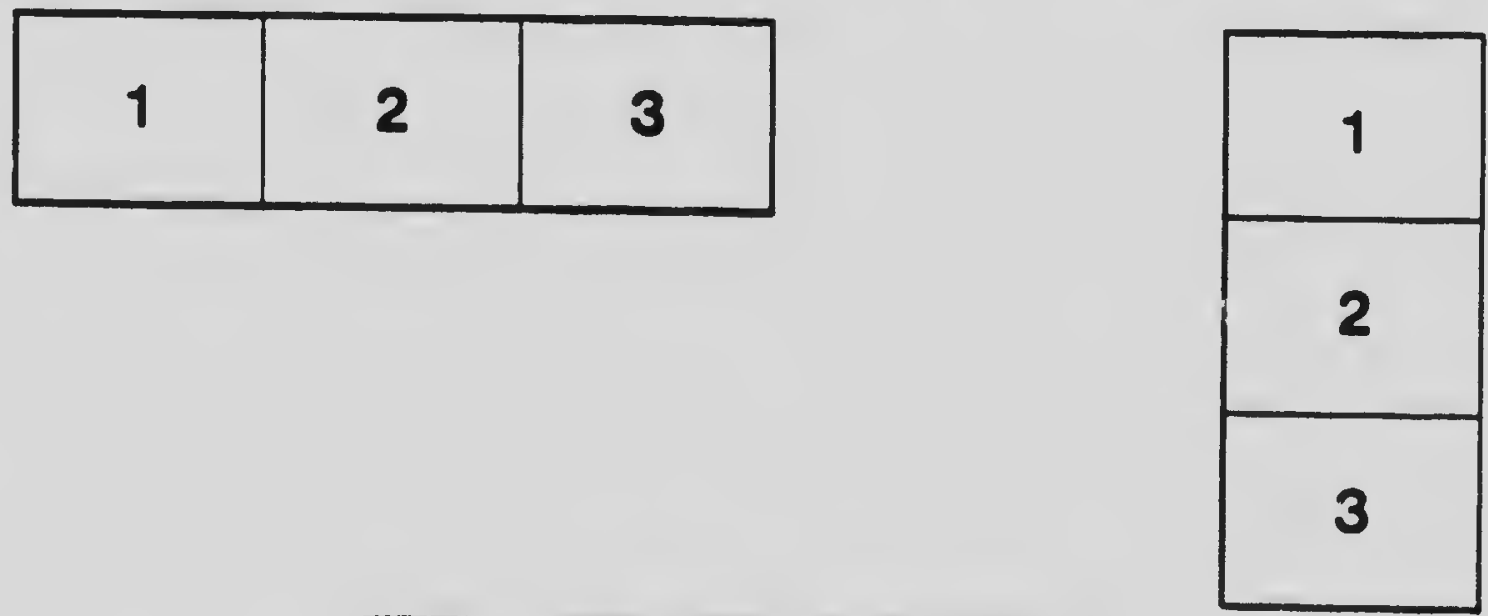

\begin{tabular}{|l|l|l|}
\hline 1 & 2 & 3 \\
\hline 4 & 5 & 6 \\
\hline
\end{tabular}



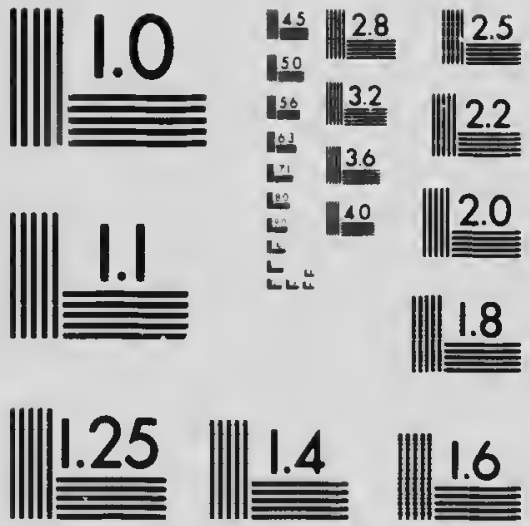

MICROCOPY RESOLUTION TEST CHART

NATIONAL BUREAU OF STANDARDS STANDARD REFERENCE MATERIAL 1010a (ANSI and ISO TEST CHART NO. 2) 
fAVORITE FISH AND FISHING 


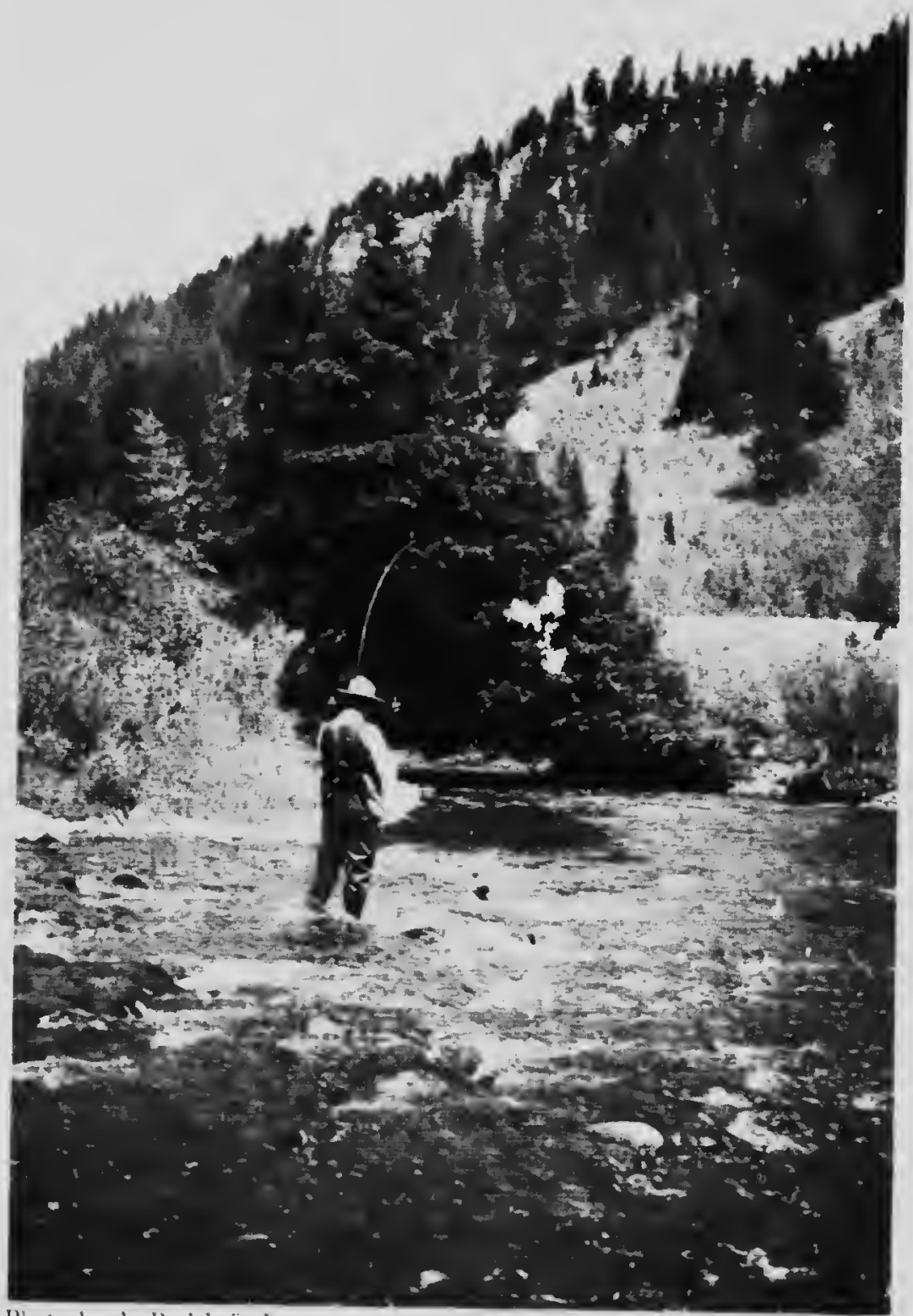

Photo by A. Raclelytic Dummore.

Conyright by combru Lifo

Grayling Fishing on Wiet Fork of Madison River, Montana. 


\section{FAVORITE FISH AND FISHING}

BY

JAMES A. HENSHALL, M.D.

Author of "Book of the Black Bass," "Camping and Cruising in Florida," "Ye Gods and Little Fishes," "Bass, Pike, Perch and Others."

"And yf the angler take fysshe: surely then" is there noo man merier than he is in his spyryte."

-Dame Juliana Berners.

TORONTO

THE MUSSON BOOK COMPANY

LIMITED 


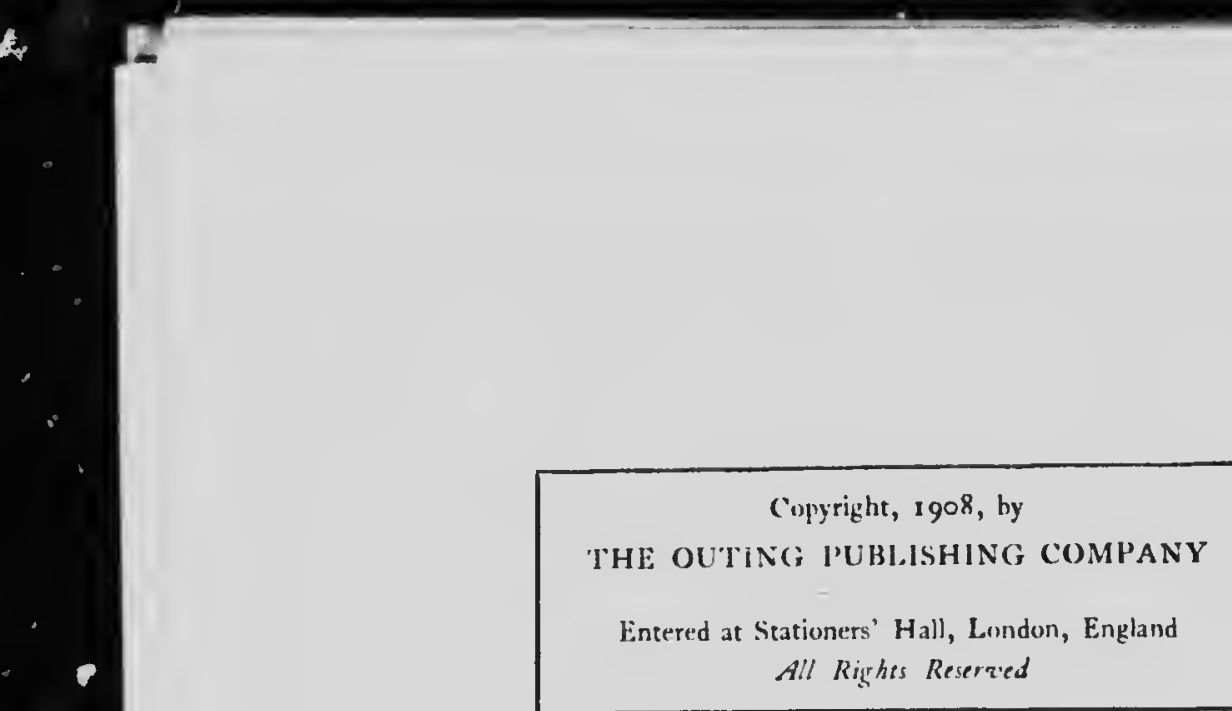




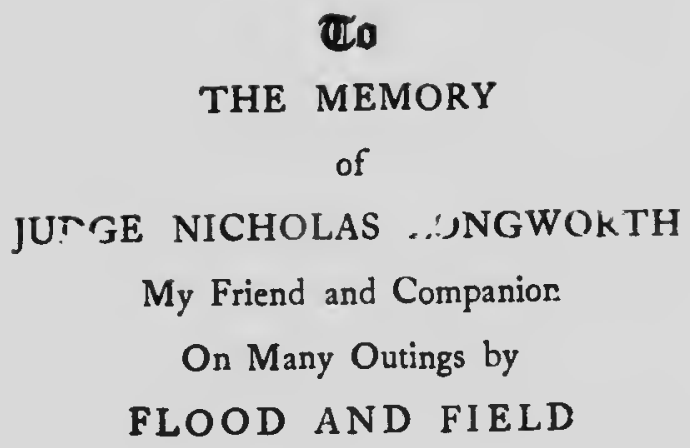




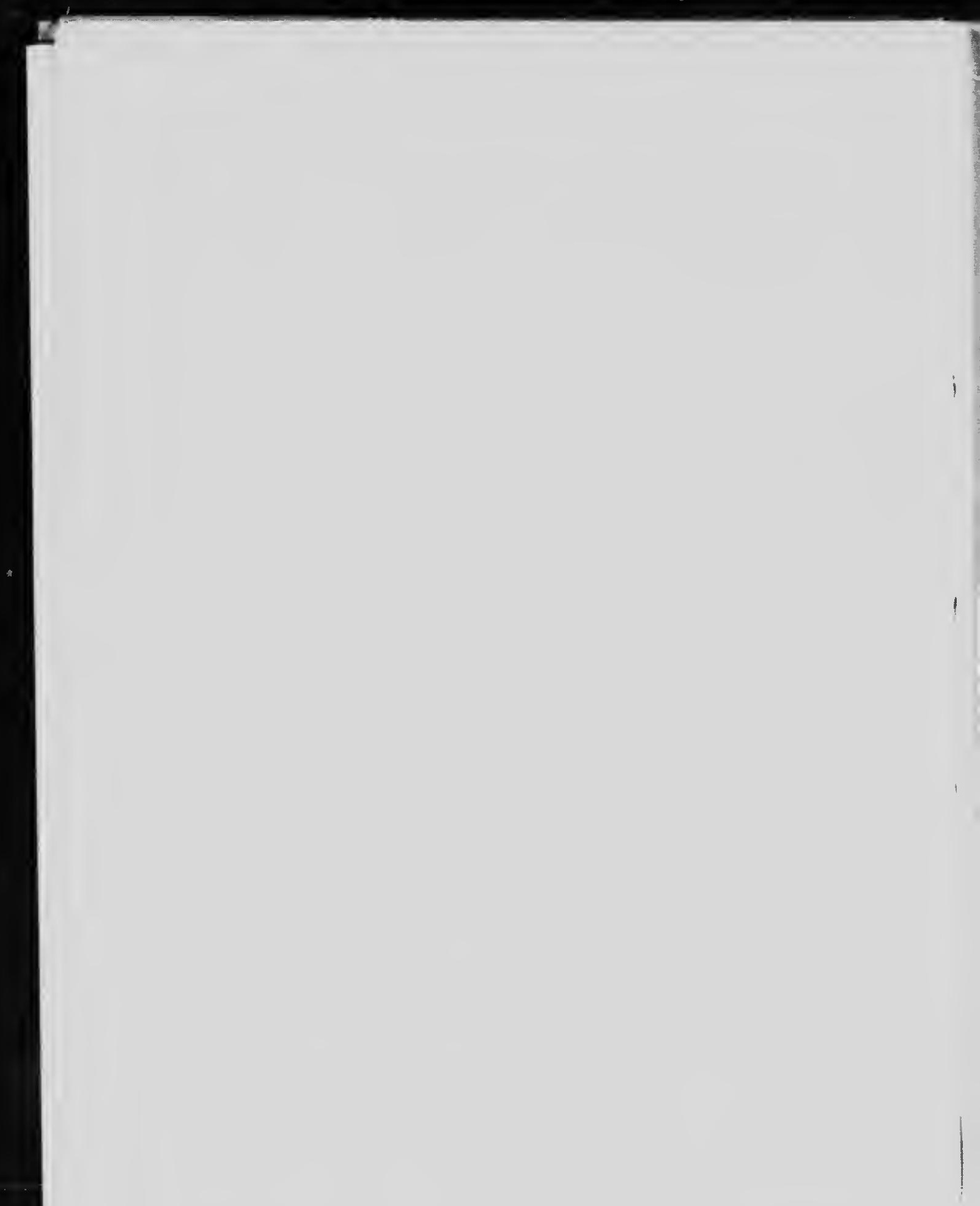




\section{ACKNOWLEDGMENTS}

This book is based on articles originally published in The Outing Magazine, Country Life in America, Shooting and Fishing, London Fishing Gazette and The American Fishculturist. My thanks and acknowledgments are hereby tendered to the publishers of those journals for permission to embody the articles in book form. For this purpose they have been added to, amplified and extended. For the illustrations of fishes I am indebted to the United States Bureau of Fisheries, Mr. Sherman F. Denton and Dr. Frank M. Johnson.

James Alexander Henshall.

Bozeman, Montana. 


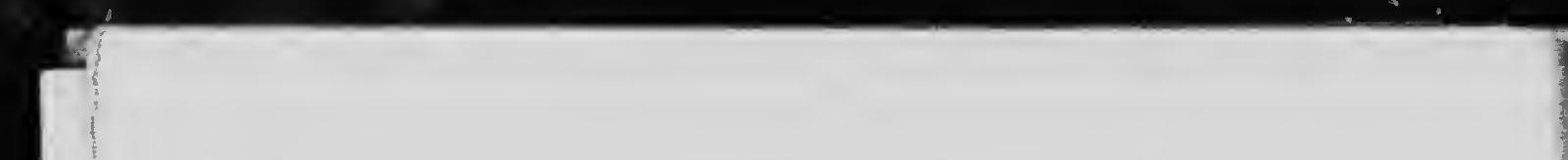




\section{CONTENTS}

The Black Bass: The Game-Fish of the page People . . . . . . 3

The Grayling: The Flower of Fishes a 43

The Trout: The Angler's Pride - . 65

His Majesty: The Silver King . . . 121

Florida Fish and fishing . . . 141 
ILLUSTRATIONS

Grayling Fishing on West Fork of Madison River, Montana

- Frontispiece

FaciNG:

Black Bass Returning to Water After Leaping .

Large Mouth Black Bass . . . . 8

Small Mouth'. Black Bass . . . . 12

Black Bass Returning to Water After Leap 32

Michigan Graving . . . . . 46

Arctic Grayling . . . . . 50

Montana Grayling . . . . 54

English Grayling . . . . . . 60

Brook Trout . . . . . . . 60

Red Throat, or Cut-Throat 'Trout . . $7^{2}$

Steelhead Trout . . . . . . 80

Rainbow Trout . . . . . . 88

Dolly Warden Trout • • . • . 9 e

Brown Trout . . . . . . roc

Biden Trout of Volcano Creek . . . 1 ob

$\mathrm{xi}$ 


\section{Illustrations}

Sunapee Tront . . . . . . 114

Tarpon . . . . . . . 128

Sheepshearl . . . . . . 142

Cavalla . . . . . . . . 144

Sea Trout . . . . . . . 146

Spanish Mackerel . . . . . . $14^{8}$

Kingfish . . . . . . . . 150

Cero . . . . . . . . 150

Redfish; Channel Bass. . . . . 154

Red Grouper. . . . . . . 156

Mangrove Snapper . . . . . 158

Ten Pounder . . . . . . 160

Ladyfish . . . . . . . 160

Snook; Rovallia . . . . . . $16+$

Jew fish . . . . . . . . . 160

Shark Sucker . . . . . . 168

Enlarged View of Sucking Disk . . . 168

Florida Barracuda . . . . 172

Northern Barracuda . . . . . 172

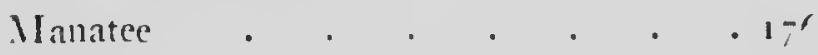

Devil Fish . . . . . . 178

xii 



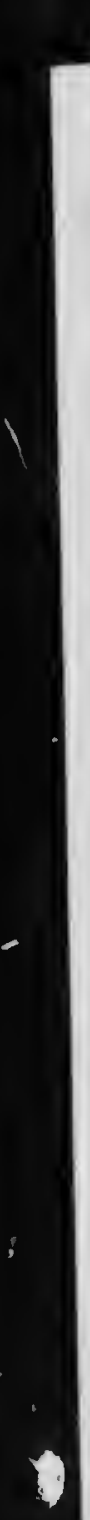

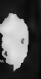




\section{Favorite Fish $\mathbb{\sigma}^{\circ}$ Fishing}

THE BLACK BASS: THE GAME FISH OF THE PEOPLE

HESE be parlous times in angling. When Williarn King, in the sevenParlous Times teenth century, with as much prophecy as humor, wrote :

“ His hook he baited with a dragon's tail And sat upon a rock and bobbed for whale,"

he builded better than he knew. And if $\mathrm{J}$ ' had lived in the twentieth century, the query: "Canst thou draw out Leviathan with an hook?" would be answered in the affirmative; also, it would be demonstrated that "He maketh the deep to boil like a pot," at Fort Myers and Catalina.

The shades of Walton and Cotton, of Sir Humphrey Davy and "Christopher 


\section{Favorite Fish and Fishing}

North," and of our own Dr. Bethune and Thaddeus Norris, could they "revisit the glimpses of the moon," would view with wonder and silent sorrow the tendency of many anglers of the present day toward strenuosity, abandoning the verdure-clad stream, with its warbling birds and fragrant blossoms, for the hissing steam launch and vile-smelling motor boat in pursuit of leaping tuna and silver ling. It goes without saying, however, that considered as a sport, fishing for these jumbos is highly exciting and capable of infusing unbounded enthusiasm, but it can hardly be called angling.

The Ethics of Sport
In the ethics of sport it may be questioned if there is not more real pleasure, and at the same time a manifestation of a higher plane of sportsmanship, in the pursuit of woodcock, snipe, quail or grouse with well-trained bird-dogs, than in stillhunting moose, elk or deer. In the former case the bird is flushed and given a chance for life, while in the latter case the quarry is killed "as an ox goeth to the slaughter." 


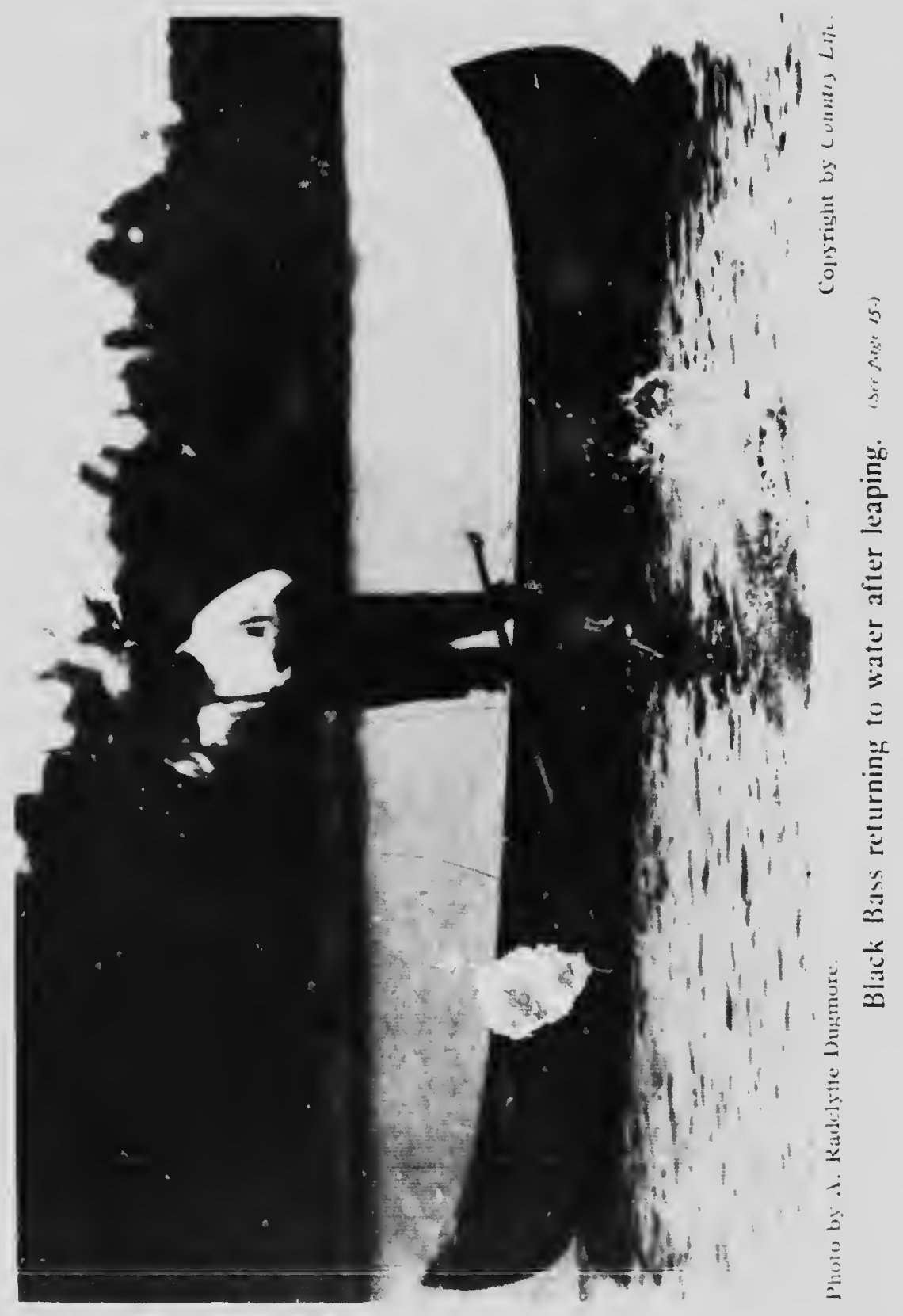




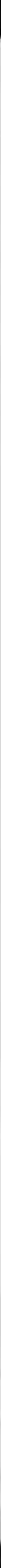




\section{The Black Bass}

So in fishing a like comparison is possible-fly-fishing for salmon, black bass, trout, or grayling is against fishing for tarpon and tuna, which are worthless when killed except as food for sharks. Ir the first case the angler's skill, and his knowledge of its habits, are pitted against the wiles of the fish, with but a weak and slender snell of silkworm fiber between its capture or escape, while in the case of the leviathans mentioned, they are handicapied by being hooked in the gullet, and by towing a boat in their strugule for ficedom. But comparisons are always odious. While the choice between the "gentle" art and strenuous fishing is certainly a question of taste, it may depend somewhat on the length of one's purse.

Black-bass fishing! These are words to conjure with. What pleasurable emotions Black Bass Fishing they call up! To the superannuated angler the words are fraught with retrospective reflections of the keenest enjoyment, while they cause the soul of the new hand to become obsessed with pleasures yet to 
The Love of Angling

\section{Favorite Fish and Fishing}

come-pleasures rendered brighter by the rosy tint of anticipation.

With the first blossoms of spring the thoughts of many men, both old and young, turn lightly to love-the love of angling. And as the leaves unfold, and the birds begin their wooing, and the streams become clear, the premonitory symptoms of the affection are manifested in a rummaging of drawers and lockers for Hy-books and tackle boxes, and the critical examination of rods and recls, and in the testing of lines and leaders. These preliminaries are the inevitable harbingers of the advent of the angling season, when black bass are leaping gayly from the waters after their enforced hibernation in the gloom and seclusion of the deep pools.

And when the encroachment of age or rheumatism forbids wading the stream, one can still sit in a boat on a quiet lake and enjoy to the full the delight and fascination of "bass fishing." What farmer's boy in the Middle West does not look forward to a Saturday when the ground is too wet to 6 


\section{The Black Bass}

plow or plant, when he can repair to the creek or pond with his rude tackle and realize his fond dreams of fishing for black bass! And when such a day arrives, as it is sure to do, how he hurries through the chores, and with what sanguine hope he digs for angle-worms in the garden, or nets crawfish or minnows in the brook, each one good for at least one "sockdolager" of a bass. For it sometimes happens that a bass will take a wriggling earth-worm or a "soft craw" when it will not deign to notice the choicest minnow or the most curningly devised artificial fly.

And the country lad always knows just where an old "whopper" of a bronze-back black bass has his lair beneath the roots of a big tree, or under the ledge of a mossgrown rock. To do future battle with such an one has engrossed his thoughts by day and his dreams by night, ever since the Christmas tree for hin bore such fruit as a linen line, a red and green float and a dozen fishhooks.

The triumphal march of a Roman war- 
"A Riband in the Cap of Youth"

\section{Favorite Fish and Fishing}

rior, with captives chained to his chariot wheels, entering the gates of the Eternal City with a blare of trumpets and the applause of the multitude, was an event to fill his soul with just pride-but it descends to the level of vainglory and mediocrity when compared with the swelling heart of the lad as he enters the farmhouse kitchen with two or three old "lunkers" of black bass strung on a willow withe. Many times during his homeward march had he halted to admire the scale armor and spiny crests of his captive knights!

And then to an appreciative audience he relates, in a graphic manner, how this one seized a minnow, and that one a crawfish, and the other one a hellgramite-and how often each one leaped from the water, and how high it jumped-and how the "ellum" rod bent and twisted as the large one tried to regain the hole under the big rock-and how the good line cut the water in curving reaches and straight lines as another one forged toward the sunken roots of the old sycamore. And then came the 


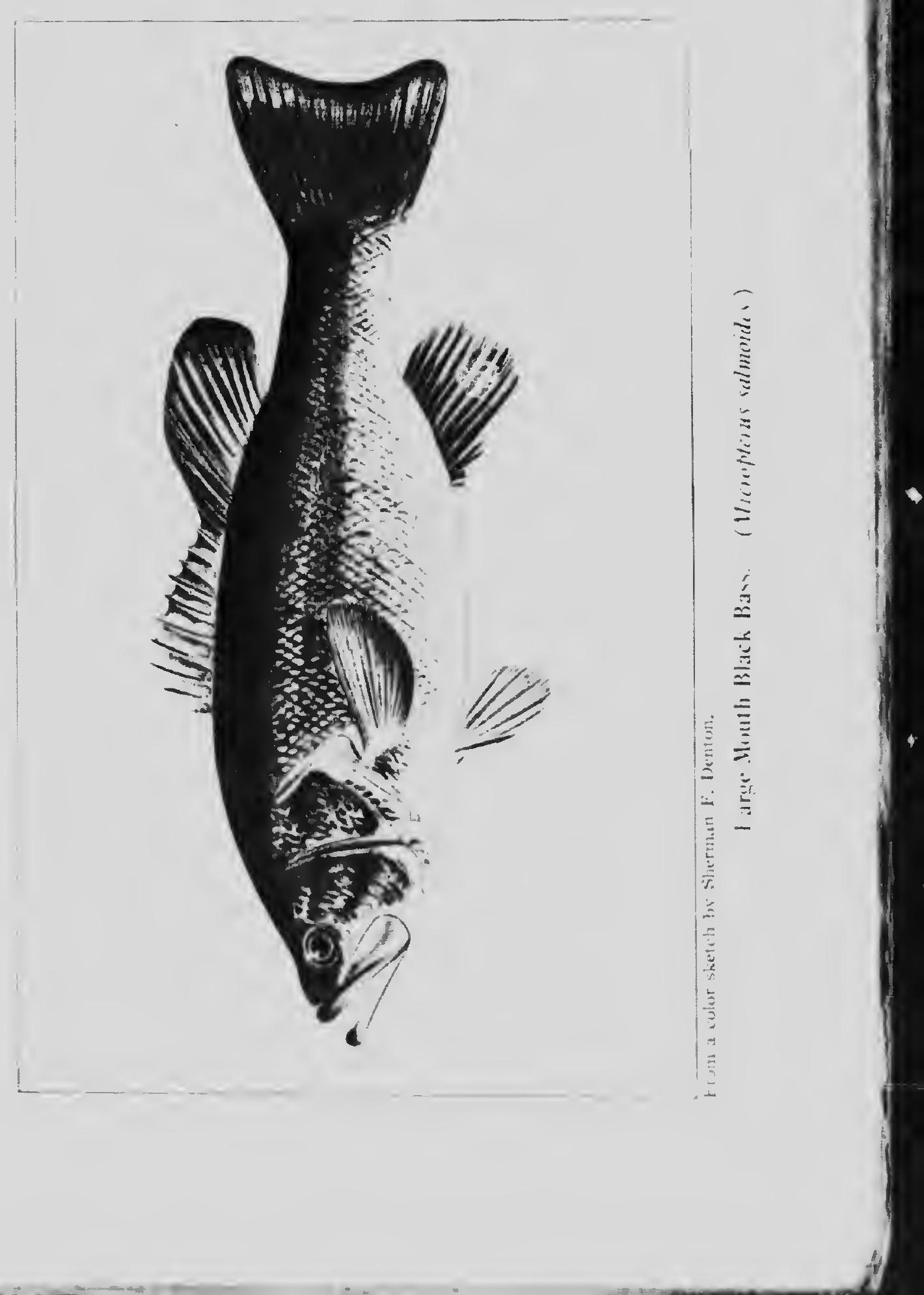




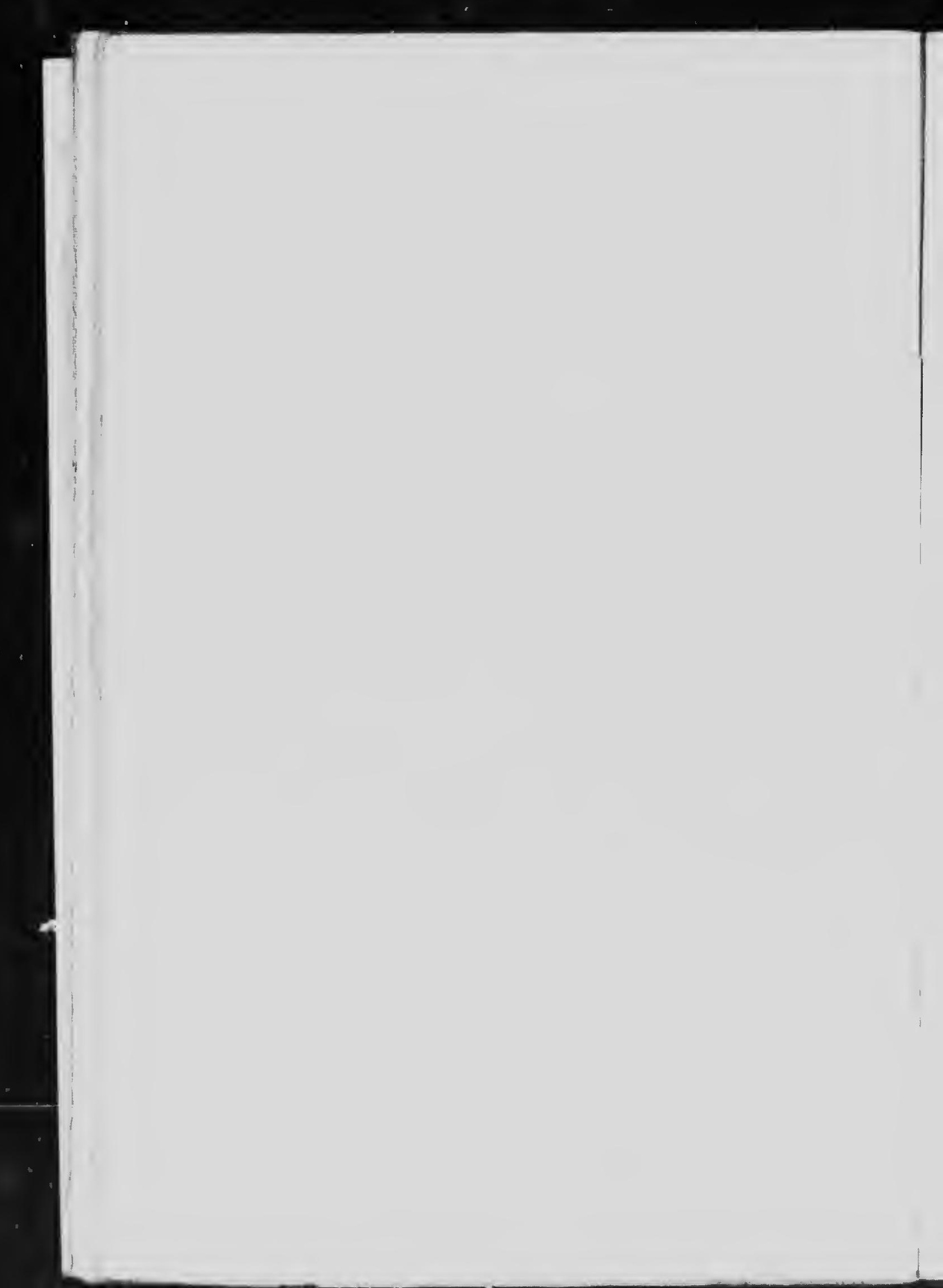




\section{The Black Bass}

climax, as, with pride and regret struggling for mastery, and "suiting the action to the word and the word to the action," he tells again the old, old story of how the biggest of all, a regular "snolligoster," shook ort the hook and got away!

In the years to come, will that lad exult over the capture of a mighty tuna or giant tarpon with as much genuine joy and enthusiasm as over that string of bass? Well, hardly. And as the boy is father to the man, and as we are all but children of larger growth, the black-bass angler ncver outlives that love and enthusiasm of his younger days-younger only as reckoned by the lapse of years.

Although the black bass, as a game fish, In Olden Time has come into his own only during the last two or three decades, black-bass fishing is nlder than the Fedcral Union. The i old naturalist, William Bartram, the " ndfather o: American ornithology," in 1764 , described, minutely, "bobbing" for black bass in Florida, there, as in all the Southern States, called "trout"-a 
Favorite Fish and Fishing

name bestowed by the English colonists owing to its gameness. While black-bass fishing is comparatively a recent sport in the Uastern States, it was practiced in Kentucky, Tennessee and southern Ohio before the end of the eighteenth century. In I 805 George Snyder, the inventor of the Kentucky reel, was president of the Bourbon County Angling Club at Paris, Kentucky. Fly-fishing was practiced as early as i 840 on the Elkhorn and Kentuckv rivers by Mr. J. I. Sage and others. His c'ick reel, made by himself, is now in my possession; and George Snyder's own reel, made in is Io, a small brass multiplying reel running on garnet jewels, is still in the possession of Appearance and his grandson at Louisrille.

Habits

The black bass is now an acknowledgeci peer among game fishes, and taking him by anc: large excels them all, weight for weight. The generic term black bass, as here used, includes both the large-mouth hass and the small-mouth bass. The two species are as much alike as two peas in a pod, the most striking difference between 


\section{The Black Bass}

them being that one has a larger mouth and larger scales than the other. When subject to the same conditions and environment, they are equal in game qualities. The habits of the two species are similar, though the large-mouth bass is more at hoine in ponds and weedy waters than the small-mouth bass, which prefers running streams and clear lakes. Their natural food is crawfish, for which their wide mouths and brush-like teeth are well adapted, though they do not object to an occasional minnow or small frog.

Owing to the wide distribution of black Now and Then bass, fishing for it is universal. It is no less enjoyed by the rustic youth with peeled sapling rod and crawfish bait than by the artistic angler with slender wand and fairylike flies. W'hile black-bass fishing was known and practiced in the Ohio Valley from the earliest years of the nineteenth century, as just stated, our angling books for three-fourths of the century contained but little, if anything, about the black bass, as they were mostly compilations from 


\section{Favorite Fish and Fishing}

English authors. The only exception were the books of Robert B. Roosevelt, an uncle of the President, who fished for black bass in Canada about I860. At the present day there are more articles of fishing tackle made especially for black bass than for all other game fishes combined. This is proof that it is the most popular and, all things considered, the best game fish of America.

The Charm of Angling
Salmon fishing, the grandest sport in the curriculum of angling, is now an expensive luxury. There is but little free water readily accessible, for all the best pools are in the possession of wealthy clubs. The bold leap of the salmon, when hooked, the exciting play of the fish on the rod, and the successful gaffing, are as so many stanzas of an epic poem. Trout fishing is a summer idyl. The angler wades the merry stream while the leaves whisper and rustle overhead, the birds chirp and sing, the insects drone and hum, the cool breeze fans his cheek, as he casts his feathery lures, hither and yon, in eager expectation of a rise. 


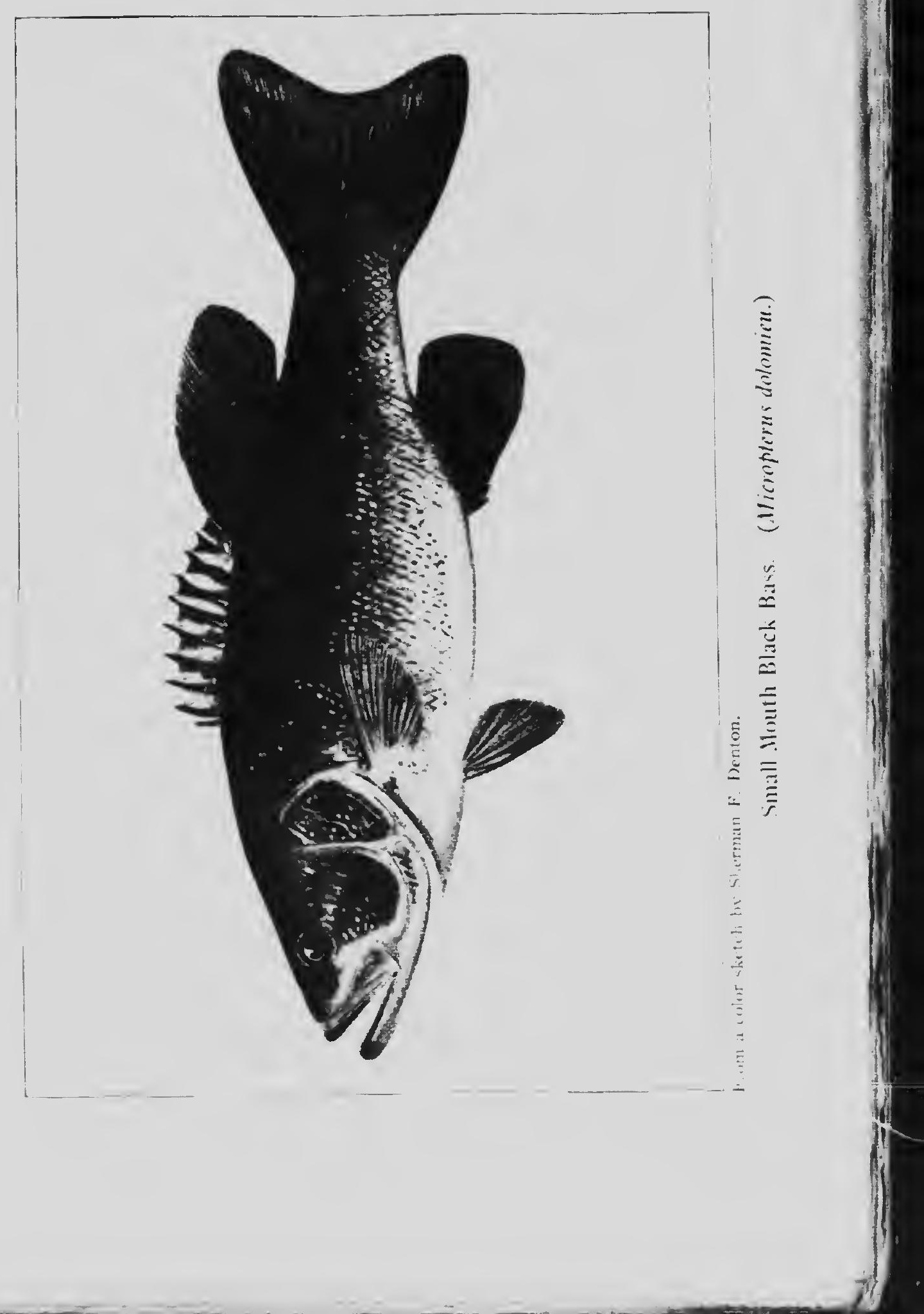




\section{The Black Bass}

Black-bass fishing combines, in a measure, the heroic potentialities of salmon fishing with the charms of trout fishing. The leap of the bass is no less exciting than that of the salmon, and is oftener repeated, while in stream fishing the pastoral features of trout fishing are experienced and enjoyed.

The leap of a hooked fish is always an exciting episode to the angler with red The Leap of blood in his veins-exciting because as an offset to its probable capture thure is the very possible contingency of its escape by throwing out the hook, or by breaking away. So with each leap of the bass the hopes and fears of the angler are constantly exercised, while his pulses quicken and his enthusiasm is aroused. Game fishes often leap a few inches above the surface in play, or to catch a low-flying insect; but when hooked they vault to a height commensurate with their agility and muscular ability. T.iey do not leap so high, however, as is commonly supposed.

A tarpon will leap six feet high, but the 
Vaulting

Ambition

\section{Favorite Fish and Fishing}

cero, or Florida kingfish, will leap higher, for it is the greatest vaulter of them all. The ladyfish executes a series of short, whirling leaps that puzzle the eye to follow-it is the gamest fish for its size in salt water. The leap of the flying-fish is sustained for a long distance by its wing-like pectoral fins, on the principle of the aerroplane, though its sole motive power is probably derived from its tail before leaving the water. The salt-water mullet is an expert jumper, leaping often in play, byt when pursued by an enemy its leaps are higher and longer than would be expected from its size. The brook trout, pike, and mascalonge seldom leap when hooked, though the steelhead trout and grayling both leap nearly as often as the black bass in their efforts to dislodge the hook. The leap of the salmon is a long, graceful curve, as it heads up stream. Once, while playing my first salmon. on the Restigouche, many years ago, my taut line was leading straight down the stream, when I caught sight of a salmon over my shoulder and above me, 


\section{The Black Bass}

leaping from the surface, which, to my surprise, proved to be my hooked fish-the line making a long detour in the swift water.

I have heard many anglers declare that Leap of the a black bass could leap five feet high, when Black Bass as a matter of fact they leap but a few inches, usually, and occasionally one, or at most three feet, though I think two feet nearer the limit. By an examination of Mr. A. Radcliffe Dugnore's photograph, reproduced herewith, it will readily be seen that the leaps are not very high ones. A black bass is in the air but a second or two, and to catch him in the act as Mr. Dugmore has done must be considered a wonderful achierement. The picture shows the bass returning to the water, with either the head or the shoulders at, or beneath, the surface, while the displaced water at his point of emergence still shows plainlystanding up, as it were. This proves that the bass regains the surface as soon as the displaced water, or rather before the upheaved water finds its level, which could 


\section{Favorite Fish and Fishing}

Why the Bass Leaps

rot be the case were the leaps three or four feet high.

Why does a hooked bass leap from the water? This question is sometimes raised, though the answer is plain. He leaps into the air to endeavor to dislodge the hook; this he tries to do by violently shaking his body, with widely extended jaws. He does not "shake his head," as is often said, for having no flexible neck, his head can only be thrown from side to side by the violent contortions of his body, often using the water as a fulcrum, when he appears to be standing on his tail. A dog or a cat will shake its head vigorously to eject some offending substance from the mouth, and a bass does the same thing; but as he cannot shake his body to the extent required beneath the surface, owing to the resistance of the water, he leaps above it. And if he succeeds in throwing out the hook he disappears beneath the surface and is seen no more; his object in leaping has been accomplished.

Usually, it is only surface-feeding fishes 16 


\section{The Black Bass}

that leap when hooked. Bottom-feeding fishes bore toward the bottom or struggle in mid-water. Every fish has its characteristic way of resisting capture, but any fish is more easily subdued if kept on the surface by the skill of the angler and the use of good and trustworthy tackle.

The manner of taking a bait also varies considerably with different fishes; and the Their Way with character of their teeth is a good guide to what tney feed on. For instance, the cunner and sheepshead are expert bait stealers. With their incisor tecth their habit is to pinch off barnacles and other mollusks from their attachment to rocks and old timbers, and so they nip off the clam or crab bait from the hook with but little disturbance. A trout takes a fly or bait with a rigorous snap, without investigation as to its nuture, and a black bass does much the same, giving immediate and unmistakable notice to the angler that there is " something doing."

The black bass is one of the few fislies that protects its eggs and young. It forms its nest on gravelly or rocky shoals or shal- 


\section{Favorite Fish and Fishing}

Breeding Habits lows, usually, but when such situations are not available, clay or mud bottom, or the roots of aquatic plants are utilized, especially by the large-mouth bass. During incubation the eggs are guarded and tended by the parent fish, and hatch in ten days or two weeks, the fry remaining on the nest, guarded by the male fish, for sereral days, when they disperse to find suitable hiding places, feeding on minute organisms that abound in all natural waters.

Spawning

The spawning season of the black bass Season varies considerably, owing to its extensive range and consequent variation in the temperature of waters. In Florida and the extreme South it is as early as March or April, in the Middle West in May or June, and at the northern limit of its distribution as late as July. Owing to this rariation, laws to protect the species during the breeding season must vary accordingly. Is the brooding fish are easily taken from their nests with snare, jig or spear, the laws for their protection should be rigidly enforced, otherwise a pond or small lake might soon 


\section{The Black Bass}

be depleted wherc the poacher is much in evidence.

The large-mouth bass grows to a maxi- Size and mum weight of six to eight pounds in Weight mum weight of six to eight pounds in Northern waters, where it hibernates, but in Florida and the Gulf States, where it is active " "ne year, it grows much larger, in Flor. "twenty pounds in rare cases. The sm..1-mouth bass has a maximum weight of ure or six pounds, though sereral have been recorded of fully ten pounds, from a lake near Glens Falls, N. Y. As usual with most other game fishes, the largest bass, as a rule, are taken with bait. For instance, the heaviest I erer took in Florida on the artificial Hy weighed fourteen pounds, and with bait, twenty pounds. In Northern waters the heaviest rach with the fly, of small-mouth bass, seldon exceeds three pounds-usually from onr to two pounds, and for large-mouth bass pound or two more, while with bait larger lish of both species may be taken.

Oring to the variable conditions mentioned the season for black-bass ishing 
Favorite Fish and Fishing

Season ing Fish:-

Distribution

varies likewise in different sections of the country. Thus, both bait- and fly-fishing are practiced in Florida during winter. In the Middle West-Kentucky, Tennessee, Ohio, Missouri, etc.-bait-fishing is available in the early spring, and fly-fishing as well as bait-fishing in mid-summer and fall. In the Northern States and Canada both bait- and $\mathrm{Ay}$-fishing are at their best during late suminer and the fall months.

The original habitats of the black bass, either of one or both species, were the hydrographic basins of the St. Lawrence, Ohio and Mississippi Rivers. Only the large-mouth existed in the seaboaru streams of the South Atlantic and Gulf States. By transplantation the black bass is now a resident of every state in the Union. It will thrive in any water the temperature of which runs up to sixty-five degrees or more in summer. It is one of the best fishes to introduce to new waters wh re the proper colditions exist, but should never, for obvious reasons, be planted in the same waters with any species of trout. 


\section{The Black Bass}

As instances of new waters in which its increase was rapid, the Delaware, SusqueIncrease in New Waters hanna and Potomac Rivers may be mentioned. In I $\$ 54$ thirty small-mouth bass, about six inches long, were taken from a creek near Wheeling, IV. Va., and placed in the Potomac near Cimberland, Md. From this snall plant the entire river above the Great Falls, and all its tributaries, became well stocked, and has afforded finc fishing for years.

In former years the black bass was quite an important commercial fish in the Middle Commercial Fishing West, but since the enactment of laws prohibiting seining and net-fishing of streams it is not often seen in the markets, and then it is mostly from private ponds. In the States of Washington and Utah, however, where it was planted in some rather large lakes years ago, the nurkets are pretty well supplied with this delicious fish, for, barring the lake whitefish, it is the best foodfish of iresh waters. Owing to the well known improvidence of market fishermen it would be well to prohibit its sale entirely 
Favorite Fish and Fishing

Propagation

Character of Eggs

in all sections of the country when taken from public waters.

Owing to the desirability of the black bass for stocking waters, the demand for both private and public streams and ponds is far in excess of the supply. Undoubtedly the best plan for stocking is that of planting adult fish, as already alluded to. But owing to the difficulty of obtaining adult fish, the energies of fish culturists have for years been direcied to a solution of the question of supply. So far, however, their efforts have been but partially successful. The eggs of the salmon, trout, grayling, shad, whitefish, etc., can be stripped from the fish, can be separated and manipulated as easily as so much shot, and made to respond readily to fish-cultural methods. But the eggs of the black bass are enveloped in a gelatinous mass that precludes stripping, and their separation is extremely difficult, if not impossible. Consequently any aitempt at their incubation by the usual hatchery methods would prove futile.

The only feasible and successful plan is 


\section{The Black Bass}

that of pond culture. Of this there are ser- Pond Culture eral methods. One either allows the bass to proceed with their parental cares in a natural manner; or early separates the parent fish from the young fry, which are then fed and reared to the desired age for planting. The United States Bureau of Fisheries and several of the individual states pursue this plan, and supply the fry to applicants free of charge.

There are certain bayous and depressions M:llions Saved along the Mississippi and Illinois Rivers and other streams in that section which are overflowed during high water. When the water recedes many black bass and other fishes are left in the bayous, which would eventually perish upon the drying up of the water. It is the practice of the National and several state fish commissions to seine out the fish and transfer them to suitable waters, or to applicants, free of expense. In this way many waters are stocked and millions of fish saved that would otherwise perish.

The black bass rises to the artificial fly 


\section{Favorite Fish and Fishing}

Fly Fishing

as readily as the trout or grayling, if fished for intelligently. The trout takes the fly at or near the surface, while it should be allowed to sink a few inches at nearly every cast for black bass, the same as for grayling. As to files, any of the hackles, brown, black or gray, are enticing to bass, and such winged flies as Montreal, polka, professor, coachman, silver doctor and a dozen others are very taking on most waters. The most important , ules for fly-fishing, or casting the minnow, are to cast a straight line, keep it taut, and to strike on sight or touch of the fisli; that is when the swirl is seen near the fly, or when the fish is felt. Striking is simply a slight turning of the rod hand while keeping the line very taut. But more important than all other rules is to keep out of sight of the fish. The flies should be lightly cast, and by slight tremulous motions made to simulate the struggles of a live insect, and then allowed to sink a few inches or a foot. From five o'clock in the afternoon until dusk is usually the best time for fly-fishing. 


\section{The Black Bass}

The best natural bait is the minnow-a Bait Fishing shiner, chub, or the young of almost any fish, which is well adapted for either casting, trolling or still-fishing. In waters where it abounds the crawfish is a good bait, especially the shedders or soft craws, to be used only for still-fishing. The hellgramite, the larva of the corydalis fly, in its native waters, is also successful for stillfishing. A small frog is a capital bait on weady waters, where it is usually cast overhead with a very short and stiff rod. Grasshoppers and crickets are sometimes employed with a fly-rod in lieu of artificial flies, and with good results. The salt-water shrimp: where it is available, near the coastr, is also a good bait for still-fishing. Cut-bait is also sometimes useful.

In the absence of natural bait a spoon Artificial Bait or spinner, with a single hook-and more than one should not be used by the humane angler-is well adapted for casting or trolling. It should be remembered that all baits, of whatever kind, should be kept in motion. A dead minnow answers as well 


\section{Favorite Fish and Fishing}

as a live one for casting or trolling, but should be alive for still-fishing. With crawfish, worms, shrimps or hellgramites a sat should be employed to keep them from touching the bottom.

Bait-Casting

In casting the minnow it should be hooked through the lips, and reeled in slowly after each cast to imitate the n. tions of a live one as much as possible. A spoon or spinner should be reeled in much faster in order to cause it to revolve freely. The most effective way of casting, either with minnow or spoon, is by the underhand method; nearly as long, and more delicate casts can be made as by the overhead cast with short, stiff rod. The mechanics of fly- or bait-casting can hardly be expressed in words or explained without diagrams or cuts. The best plan for beginners is to accompany an old hand to the stream and witness the practical demonstration of the art.

Fishing Rods

A trout fly-rod answers just as well for black bass, with a weight of from five to eight ounces, according to the material and 26 


\section{The Black Bass}

plan of construction, and whether employed by an expert or a tyro. The rod for minnow casting, or indeed for any method of bait-fishing, should be from eight to eight and a half feet long and from seren to eight ounces in weight, as larger fish are taken with bait. For casting the frog in weedy waters a short, stiff rod of five or six feet is used by many. A few words in reference to the origin of this short rod may not be amiss, especially as I wish to make it a matter of record.

At the time of the Chicago Fair, in 1393. my old friend, James M. Clark, ?. grod The Short BaitCasting Rod angler, was superintendent of the fishisgtackle department of a large sporting goods house in that city. He informed me that he had derised a rod especially intended for casting a frog tor black bass and pike on certain weedy waters not far from Chicago.

The said rod was made by reducing the regular eight-and-one-fourth-foot Henshail rod to six feet, and it soon became popular on the waters mentioned, for by casting 


\section{Favorite Fish and Fishing}

overhead, instead of underhand, more accurate line shots could be made into the small open spaces. As the weedy character of the waters rendered the proper playing of a bass difficult or ineffectual, the short, stiff rod proved itself capable of rapidly reeling in the fish, willy nilly. Of course the pleasure of playing a fish in a workmanlike manner, as in open water, would be lost, to say nothing of denying the fish a chance for its life by depriving it of a frir field and no favor-the only sportsmanlike way.

Casting Baits

Eventually the short rod and overhead cast became popular at casting tournaments, where it was also demonstrated that by reducing its length to five and even four feet longer casts were possible. Unfortunately the use of this very short and stiff rod was extended to practical fishing, and with its use was evolved a number of casting baits that out-herod anything yet produced in the way of objectionable artificial baits. They are huge, clumsy creations of wood or metal, of an elliptical form or otherwise, and bristle with from three to 


\section{The Black Bass}

five triangics of cheap hooks; they are painted in a fantastic manner, and most of them are also equipped with wings or propellers.

The extremely short tournament tool of Twin Evils five feet, called by courtesy a rod, when employed in angling, and the cruel and murderous casting baits with twalee to fifteen hooks, are, in my opinic $\ldots . t$ evils which should be tabooed by every fairminded and humane angler. So far as the short rod itself is concerned, I have always commended its use for tournament work, but I do not favor it for open-water fishing, for reasons already given. This use of it is a matter for the consideration of those who choose to employ it. For myself, I have always found the eight-foot rod and horizontal, underhand cast equal to all emergencies of fishing for black bass, pike and mascalonge. In overhead casting the bait is started on its flight from a height of ten or twelve feet, and necessarily makes quite a splash when it strikes the water. On the other hand, with the horizontal cast the 
Lines and Hooks

Leaders and Snells
Favorite Fish and Fishing

minnow is projected to the desired spot with very little disturbance.

The only line that fulfills all requirements for fly-fishing as to weight and smoothness of finish is one of enameled, braided silk, either level or tapered. For casting the minnow the smallest size of braided, undressed silk is the only one to use with satisfaction. For trolling or stillfishing a larger size may be employed, or a flax line of the smallest caliber.

Among the many patterns of fishhooks the Sproat is the best and the O'Shaughnessy next, as being strong, well-tempered and reliable, and of practicable shape. The modern eyed-hooks, if of the best quality, can be used for both bait-fishing and flytying. Sizes of hooks for bait-fishing in Northern waters, Nos. I and 2 ; for Florida, Nos. I-O and 2-0; for artificial flies, Nos. 2 to 6.

Leaders for $\mathrm{fly}$-fishing and still-fishing should be four, or not more than six, feet long, of good, sound and uniformly round silkworm gut. A leader is not used in cast30 


\section{The Black Bass}

ing or trolling the minnow or spoon. Snells should likewise be made of the best silk. worm fiber, three to four inches long for artificial Hies, and not less than six inches for bait-fishing. It is no advantage to stain or tint leaders or snells, as they are more readily discerned by the fish than those of the natural hyaline color; and the more transparent, the less they show in the water.

And now as to reels. A light, single- Fishing Reels action click reel is the best and most appropriate for Hy-fishing, and may be either all metal or hard rubber and metal combined, the former being preferable. It can be utilized for still-fishing also, where long casting is not practiced. But for casting the minnow a multiplying reel of the finest quality is required, and the thumb must be educated to exert just the right amount of uniform pressure on the spool during the flight of the minnow, to prevent its back. lashing and the resultant overrunning and snarling of the line. This can only be mastered by careful practice. As most fine 


\section{Favorite Fish and Fishing}

multipliers are fitted with an adjustable click, it can be utilized also for fly-fishing, but it is rather heavy for the lightest flyrods. While an automatic reel answers ve well for trout fishing on small streams, its spring is too light to control the movements of a fish as large and gamesome as the black bass.

Something More About Reels
It may not he amiss, in ti:is connection, to venture a few remarks on recls in general. Elsewhere I have made the statement that the most important office of a rod was in the management of the hooked fish, and not in casting the fly or bait. Per contra, the chief function of the multiplying reel is in casting the bait, and not in reeling in the fish. The office and intention of the gearing of the multiplying reel is to prolong and sustain the initial momentum of the cast, in order that the bait may be projected to a greater distance than is possible with any single-action :cel. This is proven by the fact that there have been several devices invented whereby the handle, wheel and pinion of the reel are thrown 


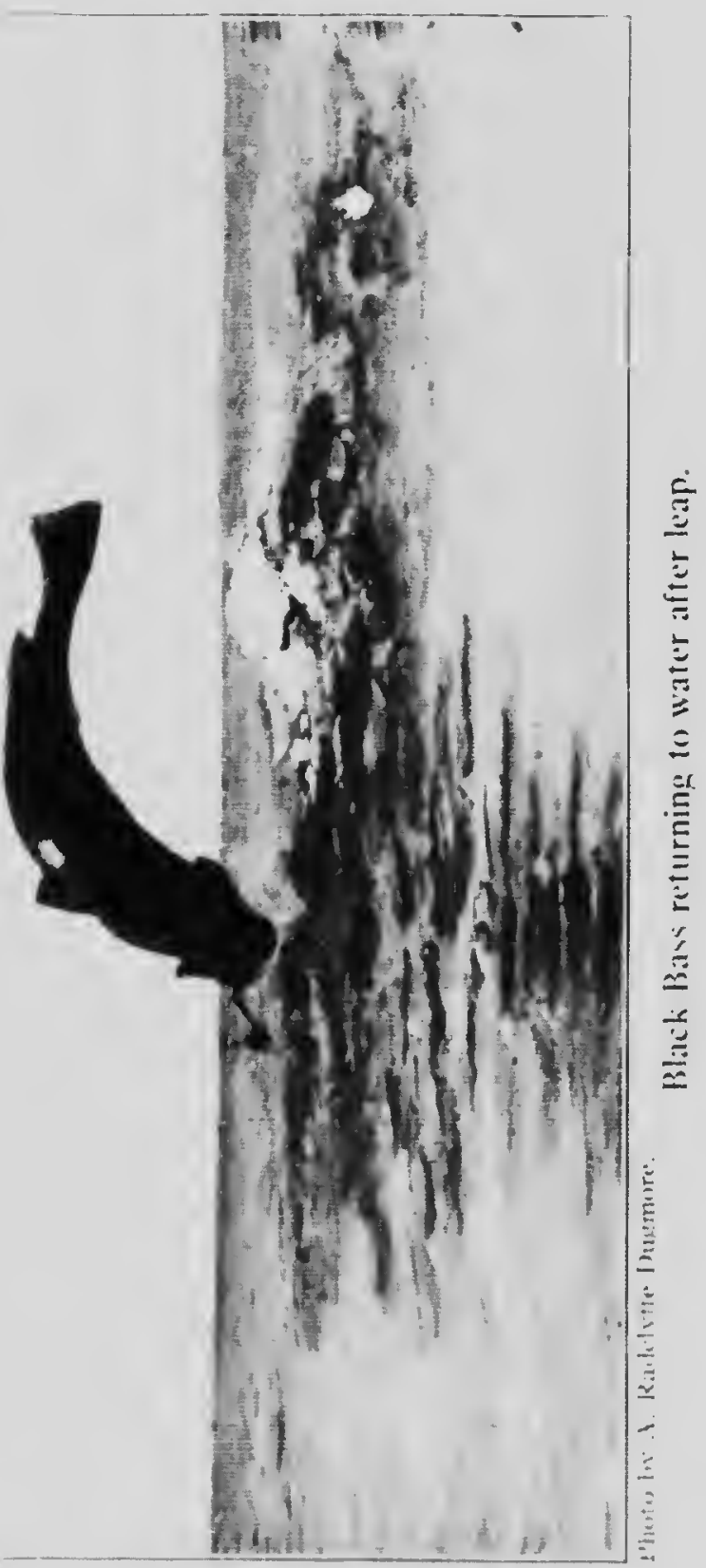




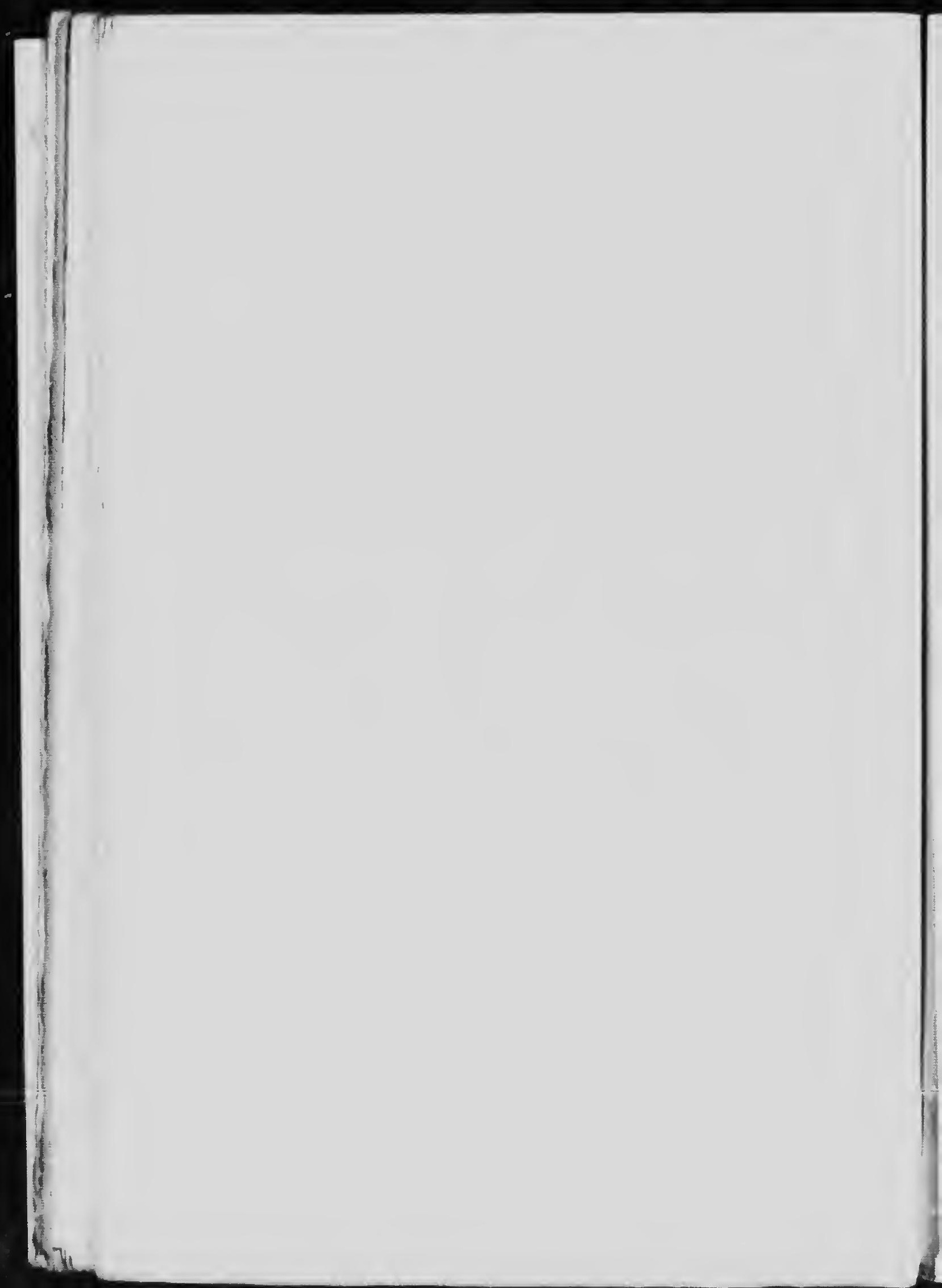




\section{The Black Bass}

out of gear to allow greater freedom to the revolving spool in casting. The theory looked feasible enough, but actual practice demonstrated that without the sustaining aid of the gears the momentum was soon lost, with the result that the bait could not be cast so far. All such devices have now been abandoned as utterly futile.

So far as the skillful management of a hooked fish is concerned, the multiplying The Reel in Use reel is no better than the single-action click reel. For tarpon, tuna, and other very large fishes, where "pumping" is practiced on the hooked fish, the largest multiplying reel is of advantage in rapidly taking up the resultant slack line. And so far as "power" is concerned, in reeling in the fish on a strain, the single-action reel has the advantage, for the force applied to the crank acts directly on the shaft of the spool, while in the multiplying reel much of the force is lost by being distributed through the gears to the shaft.

There is a tendency of late years, especially with the heavy rods fc. tuna and tar-

Position of Reel on Rod 


\section{Favorite Fish and Fishing}

The Reel on Top

The Reel Underneath

pon fishing, and also with the very short rod used in overhead casting for black bass, to place the reel on top with the handle to the right. While that plan is, in most cases, a matter of choice or habit, it is essentially wrong. Neither multiplying or click reels were intended to be used in that position, and because some anglers prefer to place them so is no argument that it is right.

Placing the reel on the top of the rod, on a line with the guides, and grasping the rod loosely where it balances, the reel naturally, and in accordance with the law of gravitation, turns to the under side of the rod. No muscular effort is required to keep it there, as is the case where the reel is used on top, which with heary reels is considerable. The reel and guides being on the under side when playing a fish, the strain is upon the guides, and is equally distributed along the entire rod, while with the reel gricles on top the strain is almost entirely on the extreme tip of the rod, and the friction is much greater.

With the multiplying reel underneath 


\section{The Black Bass}

and the handle to the right, the rod is held The Right Way at nearly its balancing point, with the rod hand partly over the reel, with the index or middle finger, or both, just forward of the reel, to wuide the line on the spool in reeling. The click reel being entirely behind the rod hand, and underneath, at the extreme butt, the rod can be grasped at its balancing point by the left hand, and the line reeled with the other.

Where the multiplying reel is placed on top, with the handle to the right, and The Wrong the thumb used for guiding the line on the spool, there is a constant tendency of the reel to get to the under side, where it properly belongs. To ove come this wabbling of the reel, and to insure more steadiness, the butt of the rod is braced against the stomach by the reel-on-top anglers-certainly a most ungraceful and unbecoming thing to do with a light rod. With the tarpon or tuna rod, and with the reel either on top or underneath, a socket for the rod butt becomes necessary in playing a very heavy fish. 


\section{Favorite Fish and Fishing}

Cesting and Playing

In casting from the reel with a light rod it is turnec' partly or entirely on top, with the right thumb on the spool. When the cast is made the rod is at once transferred to the left hand in the position for reeling in the line, with the index finger pressing it against the rod. The fish can be played with the left hand, leaving the right hand free to reel when necessary. Or in case a fish is unusually heavy and its resistance is great, the rod can be taken in the right hand, with the thumb on the spool to control the giving of line. When the opportunity occurs for reeling, the rod is again transferred to the left hand.

It is very much easier to use the reel underneath when one becomes accustomed to it, and it has been used in this way for centuries by the British angler. As the reel originated in England, it is to be presumed that the manufacturers and anglers of that country know its proper position on the rod.

Trolling

While fly-fishing and casting the minnow may be practiced wherever the black bass is found, on stream or lake, there are other 36 


\section{The Black Bass}

mtihods of angling that depend somewhat on local conditions. Trolling with the minnow or trolling-spoon is sometimes practiced on lakes, as in Michigan, Wisconsin and Minnesota. There is no skill whatever required for trolling with handline and spoon, as the bass hooks himself, when hooked at all, and is simply dragged into the boat without ceremony. It is a method of fishing that would better be "honored in the breach, than the observance." And as the rod generally used for trolling is rather stiff and heavy, it does not require the skill and cleverness to play and land the fish that are demanded by the light and pliable rods employed in casting the fly or minnow.

Skittering with a pork-rind bait is prac- Other Methods ticed on some Eastern ponds, and casting the frog overhead with a very short rod is a method that originated with some Chicago anglers. Fishing with one or a group of hooks dressed with a portion of a deer's tail and a strip of red flannel, forming a kind of tassel and known as a "bob," is 


\section{Favorite Fish and Fishing}

practiced in the Gulf States. A very long cane rod and a very short line comprise the rest of the equipment. The bob is danced on the surface in front of the boat in the weedy bayous, d is certainly effective in catching bass.

Still-Fishing

Still-fishing from the bank or a boat may be practiced wherever bass are found. Any kind of rod is used, from a saplin a a split-bamboo, with almost any kind i line or hook, and natural bait of any kind may be employed, with or without a float. It is the prinitive style of angling. I think the paradise of the still-fisher may be found on a Florida lake. Anchoring his boat near the shore, just outside of the tringe of pondlili. and bonnets, he splits the stem of a water lily, takes from it a small worm that haibors there, impales it on his hook, and casts it in a bight anid the rank growth of vegetation, where it is soon taken by a minnow of some sort, which in turn is cast into the deeper water beyond the border of aquatic plants, on the other side of the boat, where a big bass is lying in wait for just 38 


\section{The Black Bass}

such an opportunity. And so he proceeds, Ad Infinitum ad infinitum, casting on one side of the boat for his bait, and on the other side for his bass. "First the blade, then the ear, after that the full corn in the ear." 


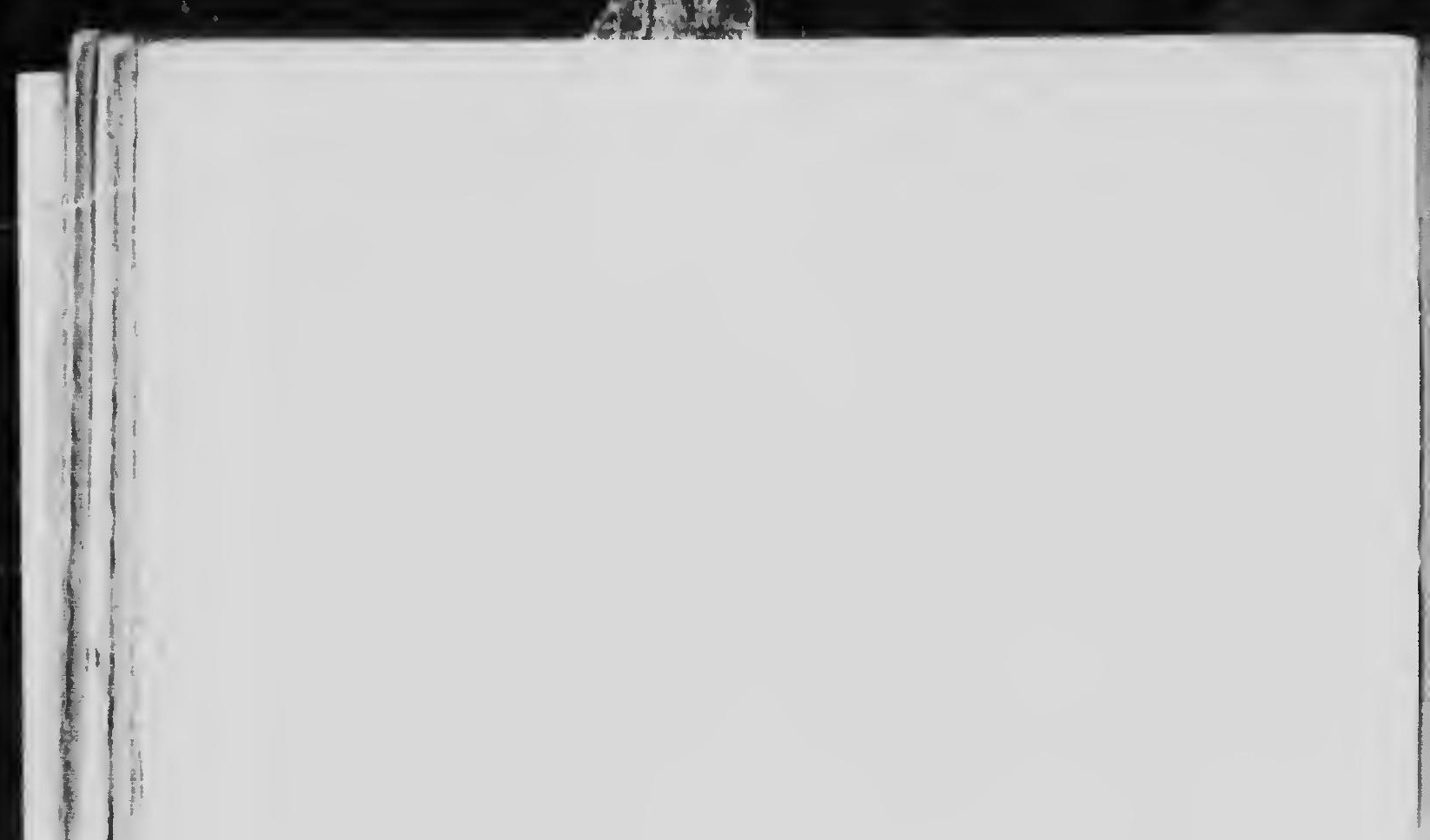


THE GRAY ING: THE FLOW:

O $\mathrm{F}$ : LES 


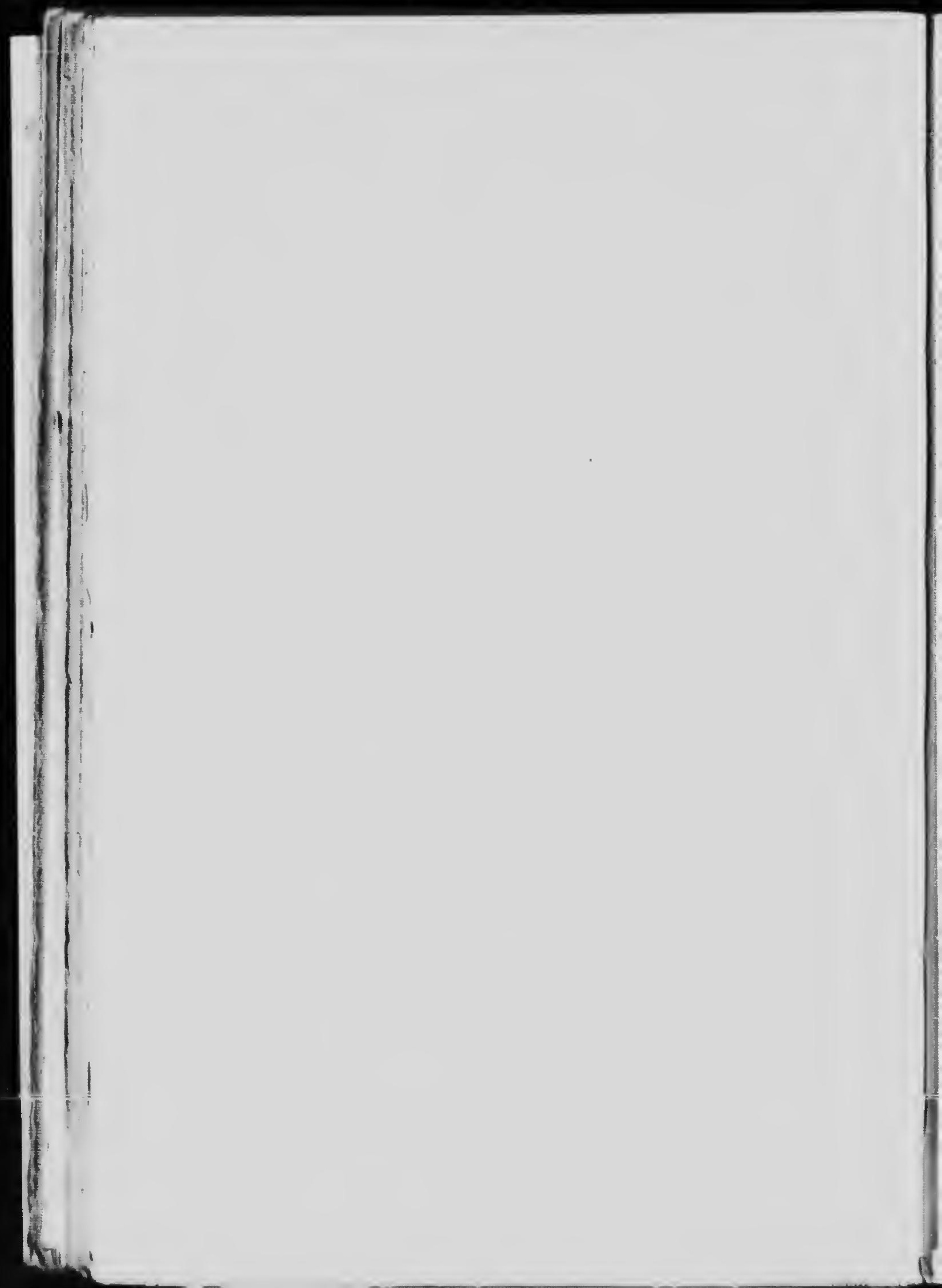




\section{THE GRAYLING: THE FLOWER OF ISHES}

QT. AMBROSE, the good Bishop of Milan, in a sermon to the fishes, apostrophized the grayling as the "Hower of fishes," as being the most beautiful, fragrant and sweetest of all the finny tribe. The saintly bishop was quite right in his estimation of the graceful, gliding grayling. It possesses a refined beauty and delicacy that is seen in no other fish, and it well merits its appellation of the "lady of the streams."

Dame Juliana Berners, prioress of the nunnery of Sopwell, near St. Albans, EngDame Juliana land, was the author of the first book on Berners angling in the English language-printed in 1496 . This "Treatyse of Fysshynge with an Angle" has served as the inspiration and model for all subsequent angling authors from Izaak Walton to the present 


\section{Favorite Fish and Fishing}

day. Dame Juliana was really the first author to mention fly-fishing in a definite sense, though Elian in his "History of Animals," A.D. 230, says that the Macedonians fished in the river Astræus with an imitation of a fly called hippurus.

Dame Juliana in her treatise gives a list of "XII flyes wyth whyche ye shall angle to ye trought and grayllyng "; and now, after the lapse of four centuries, artificial flies constructed after her formulas would prove as successful as any of the new fangled, up-to-r'ate creations. In fact, most of her flies are in use to-day under various names; and any of them tied on very small hooks would answer admirably for the graylings of Amcrica.

The Graylings

There are three closely allied species of grayling in America, and two or three in Europe. Wherever found they inhabit the coldest and clearest streams. Their distribution in this country is restricted to welldefined and limited areas. One, known as the Arctic grayling, is abundant in Alaska and the adjoining Mackenzie district of 44 


\section{The Grayling}

British Columbia. A second species is native to Michigan, and the third is found only in Montana.

The first mention of the grayling and grayling fishing in America was that of Sir The Arctic John Richardson, in the narrative of the Grayling Franklin Expedition to the North Pole, in 1819. Dr. Richardson called it "Bach's Grayling " in honor of a fellow officer, a midshipman of that name, who took the first one on the Hy. He gave it the techuical specific name of signifer, meaning "standard bearer," in allusion to its tall and brilliant dorsal fin.

Regarding the gameness of the grayling, Dr. Richardson says: "This beautiful fish inhabits strong rapids . . . It bites eagerly at the artificial fly and, deriving great power from its large dorsal fin, affords much sport to the angler. The grayling generally springs entirely out of the water when first struck by the hook, and tugs strongly at the line, requiring as much dexterity to land it safely as it would to secure, a trout of six times the size." 


\section{Favorite Fish and Fishing}

The Michigan Grayling

The Montana Grayling
Tle Michigan grayling, in early days, was known to lumbermen and trappers as "Michigan trout," "white trout," "Crawford County trout," etc. It was first described by Dr. Edward D. Cope, in I 865 , who gave it the specific name of tri-color, in allusion to the gay coloration of the dorsal fin. Until recent years it was abundant in streams of the lower peninsula of Michigan rising from an elevated sandy plateau and flowing into Lakes Huron and Michigan and the Strait of Mackinac. In a few streams flowing into Pine Lake and Lake Michigan, as Pine, Boyne, Jordan, etc., it co-existed with the brook trout, but farther south, especially in the Manistee and the Au Sable rivers and their tributaries, the grayling alone existed. In the upper peninsula it also existed in Otter Creek, near Keweenaw.

The Montana grayling, though mentioned by Lewis and Clarke from the Jefferson River (to which fact I have recently called attention), was not recognized until seventy years later, when Professor J. IV. 46 


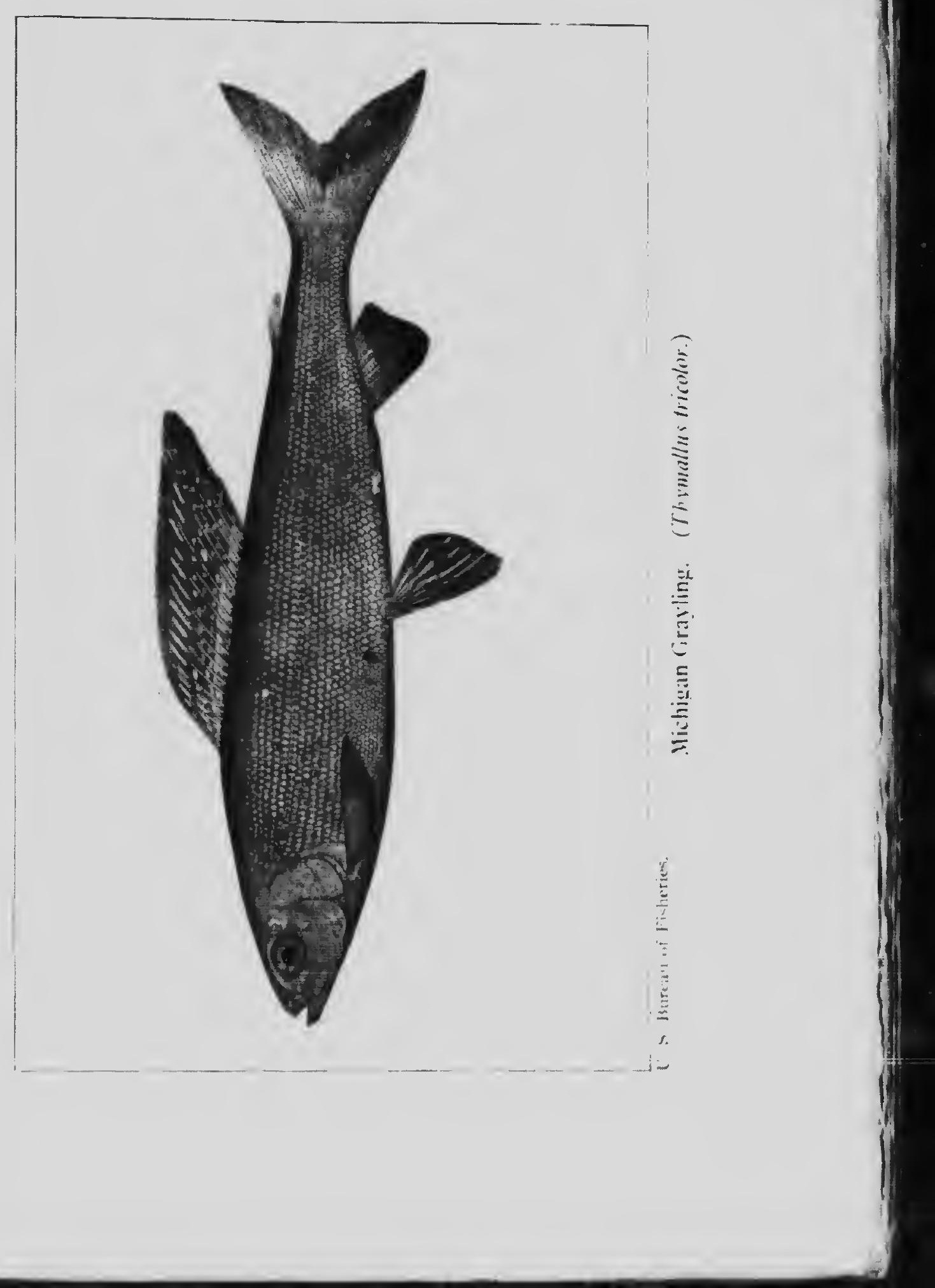




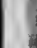

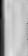




\section{The Grayling}

Milner discovered and named it montanus, in I872. So now we have the three species, Thymallus signifer, Thymallus tri-color, and Thymallus montanus. The generic name Thymallus is a very ancient one, and was bestowed originally because an odor of thyme was said by the Greeks to emanate from a freshly caught grayling. In our day the odor of thyme is not apparent, though when just out of the water it diffuses a faint and pleasant odor not unlike that from a freshly cut cucumber.

The structural differences between the three American graylings are so slight that Morphology of the Graylings they would be scarcely recognized by the lay angler, therefore a general description will probably answer. It is a slender, gracefully formed fish, with a body about five times longer than its depth, and rather thin, or compressed, on the order of the lake herring or cisco, or the Rocky Mountain whitefish. From this slight resemblance there is an erroneous notion quite current in Montana that it is a cross between the whitefish and the trout. 


\section{Favorite Fish and Fishing}

Characteristic Feature

Coloration

Its Peculiar Eye
Its characteristic feature is the tall dorsal fin, beautifully decorated with a rosecolored border, and oblong spots of various sizes of rose-pink ocellated with blue, green or white. The height of the fin is about one-fourth the length of the fish; I have several specimens of fins that are four inches tall, from fish not more than sixteen inches long.

When first out of the water the grayling might be compared to a fish of mother-ofpearl, owing to the beautiful iridescence, wherein are displayed all the colors of the spectrum in subdue tints of lilac, pink, green, blue and purple, with the back purplish gray, and a few dark, small spot in the forward part of the body. , he grivlings are closely allied to the trout family, having an adipose second dorsal fin.

The eye of all graylings is peculiar, the pupil being pyriform or pear-shaped. In all illustrations of American graylings that I have seen, except photographs, the artist has drawn the pupil perfectly round, as in most fishes. The only exception is that of 48 


\section{The Grayling}

the painting of the Montana grayling, by A. D. Turner, that accompanies the magnificent work, "Forest, Lake and River," by Dr. F. M. Johnson.

The grayling having but few teeth, and those small and slender, its food conseFood and Haunts quently consists of insects and their larvæ. It prefers swift streams with sandy or gravelly bottom, and loves the deep pools, where it lies in small schools. Occasionally it extends its search for food to adjacent streams strewn with small rocks and bowld i. Its maximum weight is one and a half pounds, very rarely reaching two pounds.

The Arctic grayling is still abundant in the Yukon and other rivers of Alaska. On the contrary, the Michigan grayling, though plentiful twenty years ago, is now nearly extinct, owing to the extensive lumbering industry. All the graylings spawn in April and May in very shallow water, and the eggs hatch within two weeks. As this is also the time wher the saw-logs descend the streams on the spring rise, they plow through the spawning beds, destroying both 


\section{Favorite Fish and Fishing}

In Michigan

In Montana

eggs and newly hatched fry. The annual recurrence of these circumstances for many years has resulted, unfortunately, in the passing of the Michigan grayling. Overfishing and the incursion of the trout have been mentioned as probable causes, but neither factor could possibly have produced the present state of things. The streams have since been stocked with brook and rainbow trout, and efforts are being made to introduce the Montana grayling.

In Montana the grayling is restricted to tributaries of the Missouri River above the Great Falls, except where recently planted. Until within the past few years it inhabited only the three forks of the Missouri-the Gallatin, Madison and Jefferson rivers and tributaries-and Smith River and tributaries below the three forks. It is still abundant in these waters and lives in amity, as it has done for all time, with the red-throat trout and Rocky Mountain whitefish.

That the grayling should inhabit only the widely separated regions of Mlaska, Michigan and Montana is remarkable. The Arc- 


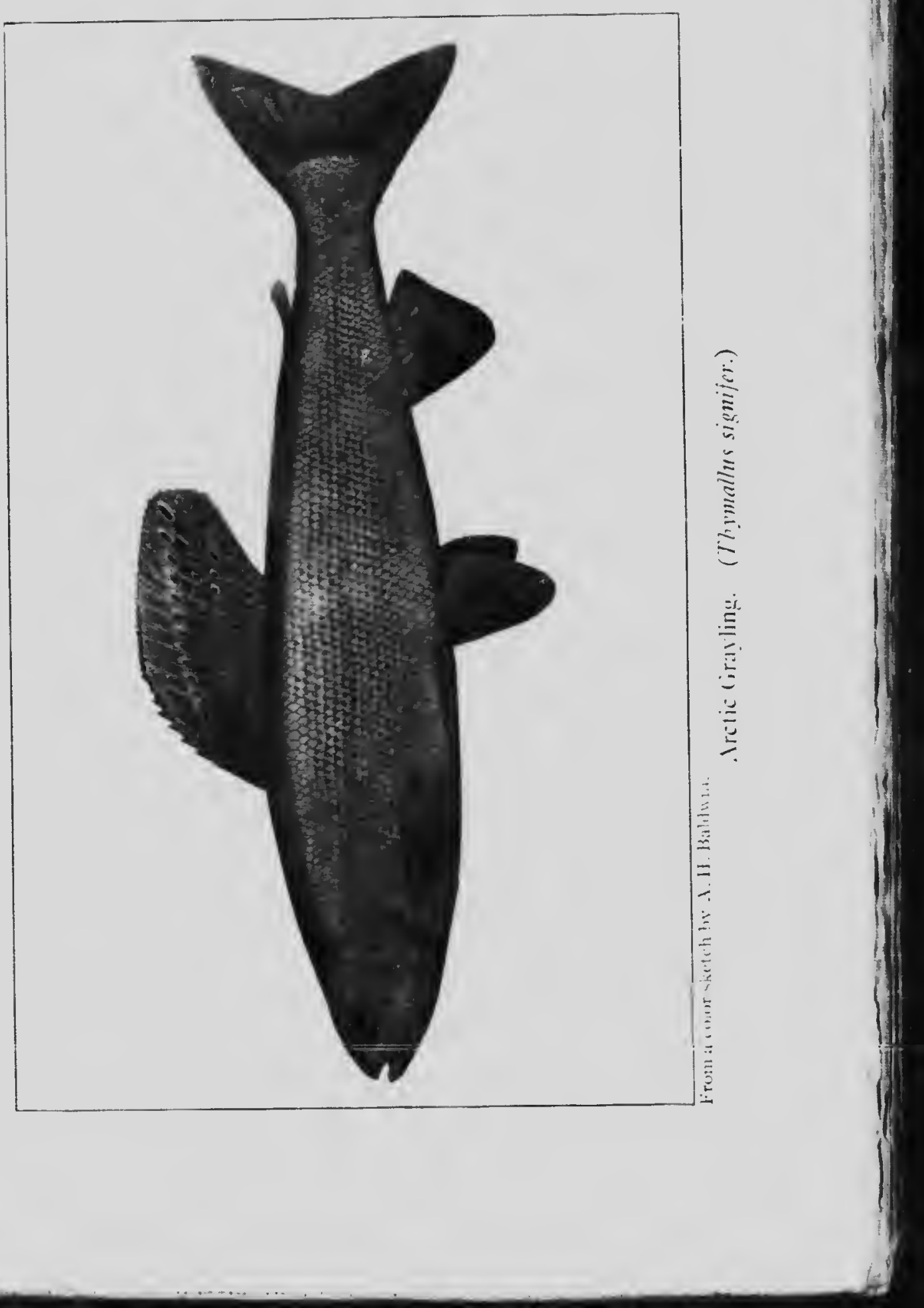




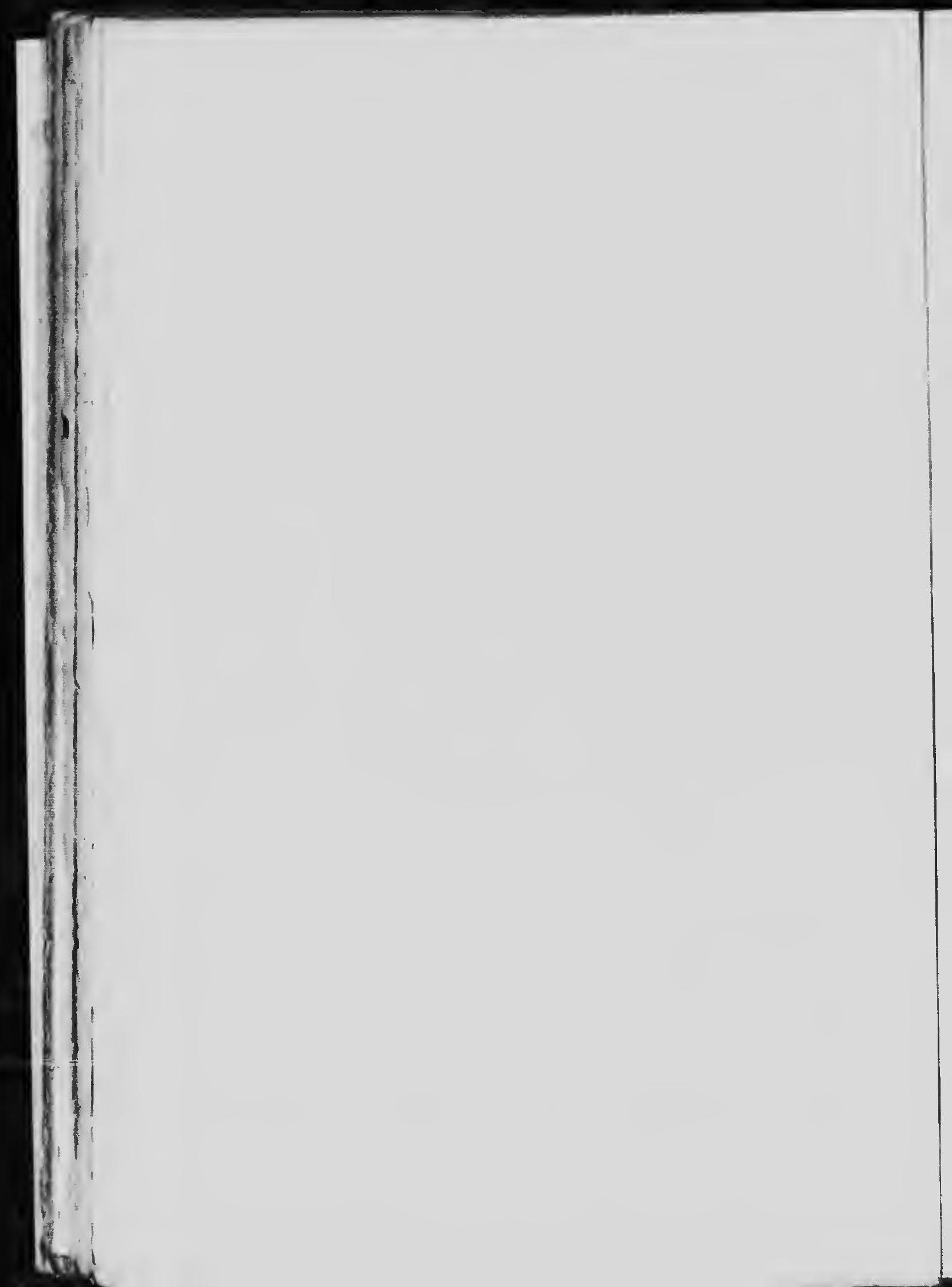




\section{The Grayling}

tic grayling is regarded as the parent stock, Distribution while the others are possibly rclics of the glacial period. This seems probable in connection with the fact that in the mountains win "e the sources of the Jefferson River irise, there is a deep lake, some four miles lo. $g$ (Elk Lake), that in addition to grayling is inhabited by the Great Lake, or Mackinaw, trout. This trout is found nowhere else west of the Great Iakes except in Canada.

Beginning with 1874 numerous attempts were made to propagate the Michigan grayPropagation of ling artificially, but after repeated failures all effort in this direction was abandoned. When a station of the U. S. Fish Commission was established at Bozcman, Montana, in $189 \%$, the Commission, under my supervision, began a scries of experiments in grayling culture, resulting in complete success, so that for several years millions of grayling have been hatched and planted, and millions of eggs have been shipped to other stations of the Bureau, where they have been hatched and planted in Eastern 


\section{Favorite Fish and Fishing}

waters. It is hoped that they may find a suitable home in some of the streams thus stocked. At the Bozeman station they have been reared to maturity, and eggs taken from these domesticated fish have been hatched. This is considered a triumph in fish-culture. Grayling eggs, by the way, are smaller than trout eggs, while the newly hatched fry are only about one-fourth of an inch long, and are quite weak for several days.

Origin of Name

The English name "grayling" is doubtless derived from its appearance in the water, where it glides along like a swiftly moving gray shadow. In Germany it is called asche, from its gray or ash color in the water. One of its old names in England on some streams was "umber," a name of like significance.

As a Game and

As a game-fish, the grayling is considered Food-Pish by those who know it hest, both in this country and England, when of corresponding size, equal to, if not superior to, the brown trout of England, the brook trout of Michigan, or the red-throat trout of 


\section{The Grayling}

Montana; while as a food-fish it is also better, its flesh being firmer, more flaky, and of greater sweetness of flavor. Likewise one can relish the grayling for many consecutive meals without the palate becoming cloyed, as in the case of the more oily trout. It never has a muddy or weedy taste.

In England there is a prevalent opinion that the grayling has a tender mouth and must be handled very gingerly when hooked; there is no truth in this notion, however, as its mouth is as tough as that of the trout; but as smaller hooks are employed in grayling fishing they are more apt to break out under a strain. For this reason the angler should not attempt to "strike" at a rising fish, but allow it to hook itself, which all game-fishes will do nine times out of ten. The only object in striking is to set the hook more firmly.

Grayling fishing is fair during summer, but is at its best in autumn; and where the Grayling streams are open it is quite good in winter. Mr. Dugmore, who made the admirable photograph illustrating this article, did his 


\section{Favorite Fish and Fishing}

fishing late in August, in the West Fork of the Mallison River, and in Beaver Creek in the upper cañon of the Madison, in Montana. The upper Madison is an ideal home for grayling, the stream being clear and swift with a bottom of black obsidian sand.

Fly-fishing for grayling differs considerably from trout fishing. The trout usually lies concealed, except when on the riffles, while the grayling lies at the bottom of exposed pools. When the fly is cast on the surface the trout dashes at it from his lair with a vim; or if below it, he often rises clear of the witter in his eagerness to seize it. Should the Hy be missed, another attempt will not be made again for some little time, if at all. The grayling rises to the Hy from the bottom of the pool to the surface with incredible swiftness, but makes no commotion in doing so. Should it fail to scize the fly it returns toward the bottom, but soon essars another attempt, and will rontinue its efforts until finally the thy is taken into its mouth. From this it is erident that the grayling is not as shy as the 


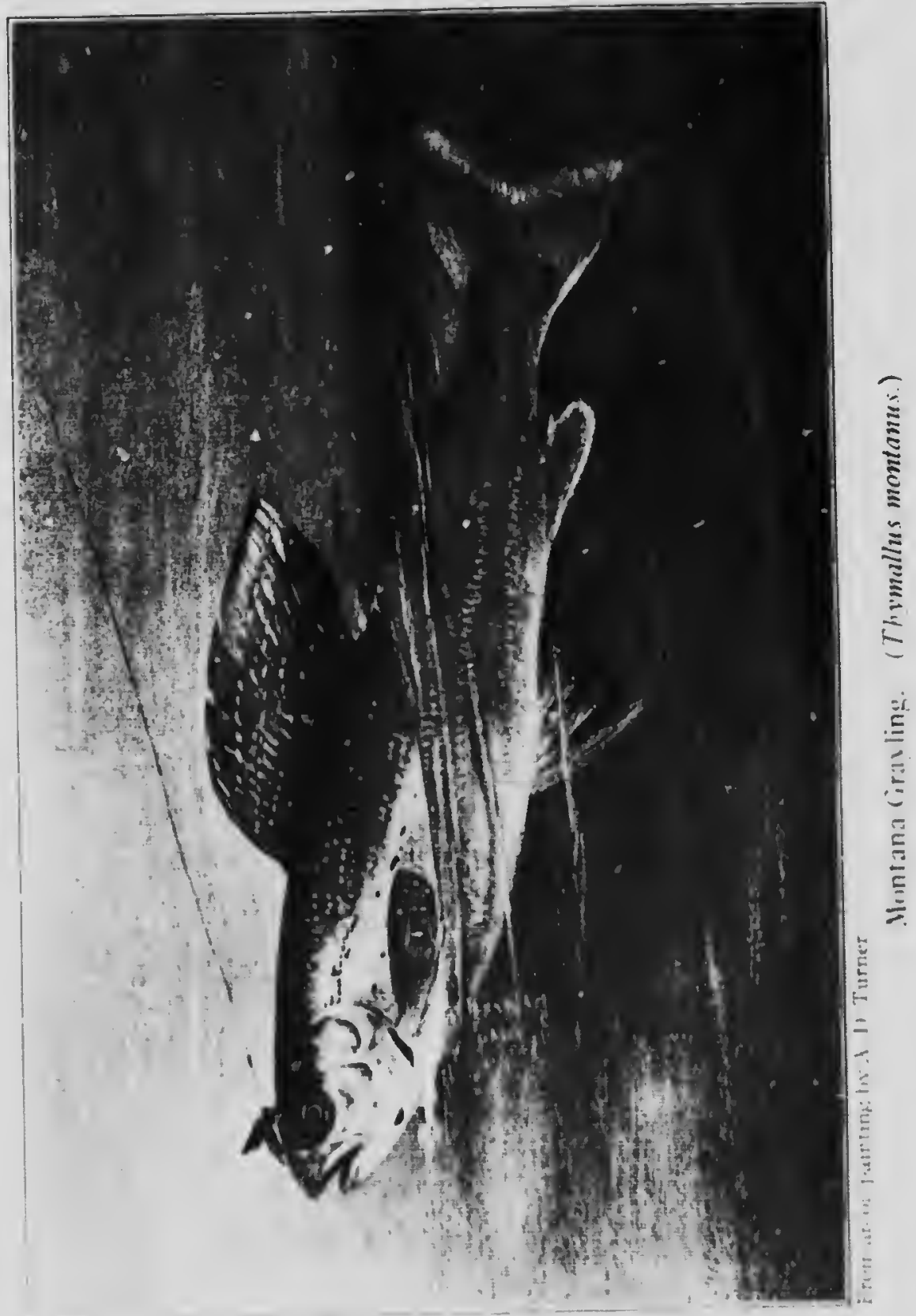



The Grayling

trout. It is also apparent that the fir should be kept on the surface for trout, but allowed to sink a few inches at each cast for grayling.

While the casts need not be as long as for trout, unless in very shallow water, Casting and Playing they should be perfectly straight, and the line be kept taut, so that the fish may hook itself upon taking the $\mathrm{Hy}$ into its mouth. When hooked, it should be ied away to one side of the pool in orcler that the rest of the school may not be alarmed. The fish should be held with a light hand, so as not to tear out the small hook, but at the same time kept on the bend of the rod until exhasted, before putting the landing-net under it. The landing-net should always be used, as the hold of the small hook may be a slight one.

Unlike the trout, the grayling of ten breaks water repeatedly when hooked, Leaping of Grayling making short but mad leaps for freedom that require considerable skill to circusvent. During the struggle the tall bannerlike dorsal fin waves like a danger-signal,

;5 


\section{Favorite Fish and Fishing}

and with the forked tail-fin offers considerable resistance in the swift water. But when safely in his creel, the fortunate angler can congratulate himself on having fairly subdued and captured this wily and coquettish beauty of the crystal waters.

Outfit for Fly-Fishing
The outfit for fly-fishing is about the same as for trout, say a rod of five or six ounces, light click reel, enameled silk line, with a foui-foot leader for two flies, or one of six feet for three, though two flies are enough. The flies should be tied on quite small hooks, Nos. 10 or I2. While ordinary trout-Hies answer pretty well, they are much better if made with narrower wings, or still better with split wings. Any of the conventional hackles arc capital, especially if the hackle is tied so as to stand out at right angles to the shank of the hook. The most successful Hies are those with bodies of peacock harl or of some shade of yellow, as coachman, grizzly king. Henshall, alder, governor, and black gnat, with bodies of harl: and professor, queen of the water, Lord Baltimore and oak fly, with yellowish 56 


\section{The Grayling}

bodies. Other useful tlies are gray drake, gray collin, and the various duns. Four of the most successful grayling flies in England are the witch, Bradshaw's fancy, green insect and red tag, samples of which were sent to me by one of the best grayling fishers of that country. They were tieci on the smallest hooks made, Nos. 16 to 20. Ail have harl hodies, very plump, with tags of red worsted, and hackles of various shades of silver gray, except Walbran's red tag, which has brown hackle. Mr. Howarth, an old English Hy-tier, of Florissant, Colorado, is an adept at tying grayling flies.

For bait-fishing the fly-rod and click reel mentioned will answer, as the bait used is Outfit for Bait Fishing very light. The line should he of braiderl silk, undressed, size $\mathrm{H}$, with a leader of three or four feet. Snelled hooks, size Nos. 7 to 9 , are about right. The hest bait is the "rock worm," is it is called in Montana, which is the larva of a caddis fly encised in an artificial envelope of minute bits of stick, or grains of fine gravel. Other baits are earthworms, grubs, crickets, grass- 
Float and Sinker

The Finest Grayling Fishing

\section{Favorite Fish and Fishing}

hoppers, natural niles, or small bits of fat meat.

In comparatively still water a quill float, or a very small one of cork, must be used to keep the bait about a foot from the bottom, with a light sinker to balance the float. In swift water the float will not be required, but the small sinker is needed to keep the bait near the boctom. My advice, however, would be to pay court to the "lady of the streams" with the artificial fly as the only fitting gage to cast before her ladyship.

The angler who visits Yellowstone $\mathrm{N}$ ittional Park, after viewing the bautics and marvels of that wonderland, and enjoying the excellent trout fishing, may go hy at regular stage line to Riverside at its wcstern boundary, and thence a few miles to the upper Madison basin. Here, within an area of a dozen miles, are several forks of the Madison River, and Beaver Crepk in the upper cañon, where he may enioy the finest grayling fishing in the world. Under the shadows of snow-clad peaks, 58 


\section{The Grayling}

and amidst the most charming and varied scenery, he may cast his feathery lures upon virgin streams of crystalline pureness, while breathing in the ozone of the mountain breeze and the fragrance of pine and fir.

There is a tradition in England that the grayling was introduced into that country The Relation of Monasteries to from the continent of Europe by the monks the Grayling and friars of olden time. This is not improbable, as the grayling was always a favorite fish with the various monastic orders throughout Europe, and there still remain in England the ruins of ancient monasteries on most of the grayling streams. As the original habitats of all the graylings are the coldest and clearest waters, the streans of England, while clear enough at times, are not of very low temperature; this would seem to give sume credence or warrant for the legend ment ined.

One can readily imagine the tonsured fathers of old-friars white, black and gray, and the hooded Capuchin and Benedictine-during the ienten season and be- 


\section{Favorite Fish and Fishing}

fore fast days, repairing to the limpid stream with rod and line in pursuit of the lovely grayling.

The Monks and the Grayling

But the angler, of all others, can realize that it was not alone to gratify the palate that the holy brothers left the dim cloister for the sunlit stream, the rosary and missal for the rod and line, and forsook the consecrated pile for God's first temples-the sylvan groves. Ind there, rod in hand, seated on the verdure-clad bank, he sees the silent and ghostly figures eagerly watching the tell-tale Hoat, fishing all day, perhaps, from the matin song of the lark to the vesper hymn of the nightingale, while they are quietly drinking in and enjoying the many bountiful gifts of Nature-the merry brook, the nodding flowers, the whispering leaves, the grateful breeze.

The Cloister and the Stream

And how the hooking of a gravlini, must have stirred the stagnant blood and quickened the pulses of those austere souls! And how the languid muscles must have stiffened, and the deadened nerves thrilled, when the gamesome grayling leaped into 60 



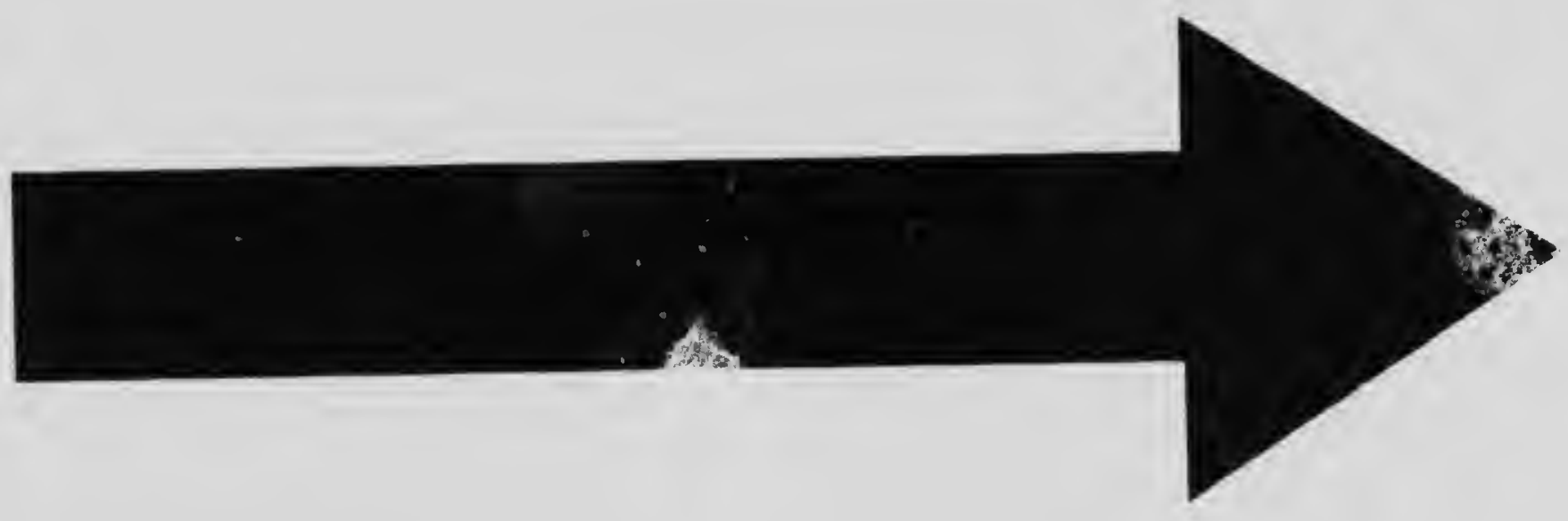



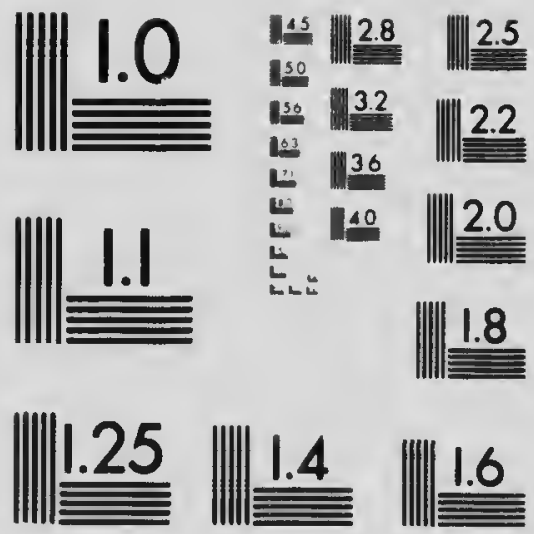

MICROCOPY RESOLUTION TEST CHART

NATIONAL BUREAU OF STANDARDS STANDARD REFERENCE MATERIAL 1010a (ANSI and ISO TEST CHART No 2) 


\section{The Grayling}

the sunlight sparkling like a gem and glittering like a crystal!

Ah! what a happy contrast to the gloomy cell and breviary it must have been to those rigid and figid celibates to view the everchanging tints and the reflected glory of the "lady of the streams" after she had coquettishly responded to their lures!

But let us return from the musty ages of the past, and the hoary fathers-those wise conservators of their beloved fish-to the present day, with the sad vanishing of the Michigan grayling as a solemn warning. Let us, then, guard and preserve this beautiful creature that has come down to us through the centuries, hallowed by the jealous care of the good fathers of yore, so that the toiler in these stirring times may, if he will, forsake the busy marts, the office or workshop, for a period, be it ever so brief, and journey even a thousand miles to enjoy-as the monks of old-the catching of a grayling.

\section{of the Past}


THE TROUT: THE ANGLER'S

PRIDE 


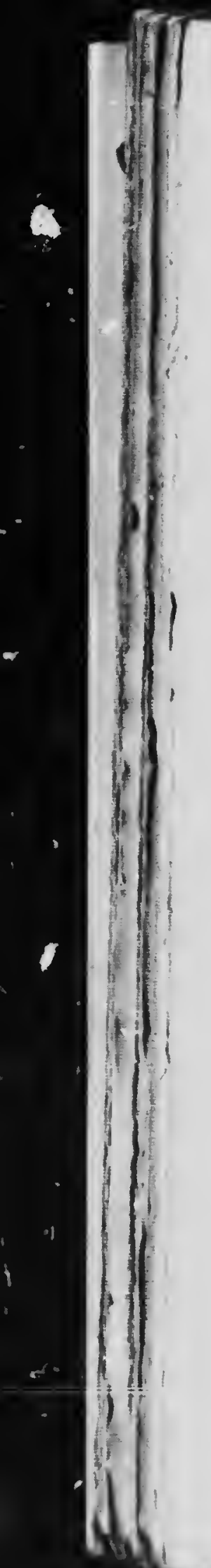




\section{THE TROUT: THE ANGLER'S PRIDE}

$7 \mathrm{HE}$ brook trout, or cha, with the 1 beautiful and suggestive name of Passing of the Salvelinus fontinalis, by which it is known to the naturalist, is fast disappearing from its native streams. The altered conditions of its aboriginal environment, owing to changes brought about by the progress of civilization, have resulted in its total extinction in some waters and a sad diminution in others. Ir many instances the trout brooks of our childhood vill know them no more. The lumbermar. has gotten in his work-the forests have disappearedthe tiny brooks have vanishel.

The lower waters still remain, but are robbed of their pristine pureness by the contamination due to various manufacturing industries. In such streams the supply 
of trout is only maintained through the efforts of the fecieral and state fish commissions. It is to be hoped that by this means the beautiful brook trout, the loveliest and liveliest fish of all the finny world, may be preserved and spared to us for yet a little while. Its introduction to the pure mountain streams of the Far West has given it a new lease of life, and the time may come when, outside of the game and fish preserves of wealthy clubs, it will be only in its new home that it can be found. On long winter evenings the angler, sitting before his cheerful fire, may be meditating on the passing of the brook troutthat his angling record for the last season was not so good as the year before, and that next summer it may be still worse. But such disheartening thoughts are quickly dispelled as his glance falls on the fly-i,ook and tackle box within his reach. His flybook is eagerly overhauled and frayed snells and leaders and rusty hooks discarded. Some well-worn flies that recall the big trout that gave him sport galore in 66 


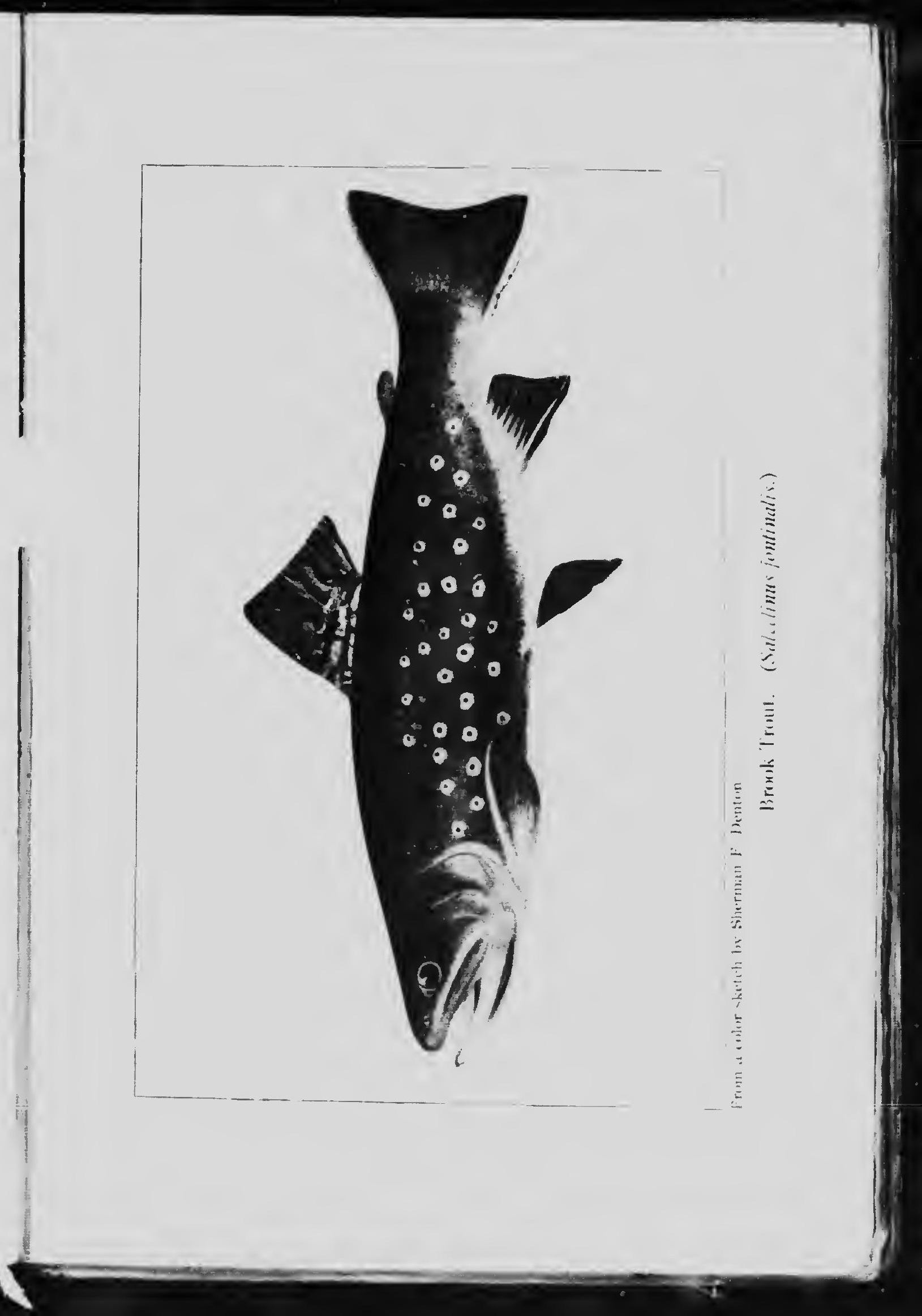





\section{The Trout}

the long summer days are, on second thought, snugly and affectionately tucked away in a separate pocket of the book, to be brought forth on occasion, to excite the en:y of some brother angler, while relating with minute detail the story of the part they took in the capture of the "big ones."

?'hrough the rings of smoke rising from Pipe Dreams '.is brier-root he sees the stream rippling and sparkling as it courses around the bend. And in fancy he is wading and casting, and as eagerly expectant of a rise, with his feet encased in slippers, as when plodding along in clumsy wading boots. The pipe-dreai.1s of retrospection are as engrossing and enjoyabie as those of anticipation to the appreci.t. 'e angler. The pleasures though passed are not forgotten.

He even smil s as he remembers the slippery and treacherous rock that caused his Pride After a Fall downfall, and the involuntary bath that followed, just as he hooked the biggest fish in the pool. He is even conscious of the chill that coursed up his spine as the stream laughed and gurgled in his submerged 


\section{Favorite Fish and Fishing}

ear-but he remembers, best of all, that he. saved the fish, and that he laughs best who laughs last. There is a saving clause of compensation in every untoward event to the philosophic mind.

Mother Nature's Sanitarium

Balm in Gilead

In " the good old summer time" thousands of weary toilers from every scation in life are leaving he home, the school, the workshop, the office, for a few weeks of rest, recreation and recuperation. And nowhere else can the overstrung nerves and tired muscles find surer relief and tone than beside the shimmering lake or brawling steeam. The voices of many waters are cailing them, the whispering leaves are coaxing them, the feathered songsters are entreating them-to leave the busy haunts of men and repair to the cool shadows and invigorating breezes of sylvan groves and shining waters.

Here, indeed, may be found a solace for every care, a panacea for every ill, furnished without cost and without stint, from Mother Nature's pharmacopoeia of simples: fresh air, pure water and outdoor exercise. 68 


\section{The Trout}

But while all of this is patent o the seasoned angler, the preachment of the resources of Nature for the relief of the "demnition grind" of those who dwell in cities cannot be too often reiterated.

Trout fishing is lawful in several states during a part or throughout the entire

Beginning of month of April; but unless $t_{i}$ - season is exceptionally forward and pleasunt the wise angler will lose nothing; by ignoring the privilege.

May and Jui.: are, by ail odds, the best months for brook trout fishing. By May Day most of the streams of the Eastern States have cleared sufficiently for Hy-fishing, and their temperature has sensibly diminished.

"About this time," as the almanacs say, Signs of Spring the most interesting literature for the impatient angler is the $c$ alogue of fishing tackle. After a final orerhauling and inspection of his tools and tackle he is impelled, irresistibly, to pay a visit to the tackle store for such additions to his stock, be it large or small, as he thinks he needs, 


\section{Favorite Fish and Fishing}

and is not happy until his wants, real or fancied, are supplied.

Embarrassment of Riches

Tools and Tackie

A woman at a bargain counter is a sedate, complacent and uninterested personage compared with an angler in a tackle store at the opening of the fishing season. He is covetous to a degree, and would walk off with the entire stock should he follow the dictates of his inclination as to his fancied requirements. As it is, he buys many things he will never have any use for; but he thinks he will, all the same, and leaves the attractive place an impoverished but happier man.

Of course it is best, when one can afford it, to provide duplicate rods and reels and a liberal supply of minor articles. But the careful angler, with but one ewe lamb in the shape of a tried and trusty rod, and a sing!e, reliable click reel, with a limited but wellselected supply of leaders and Hies, will take as many fish as his prodigal brother with a superabundant equipment.

The length and weight of the rod depends on the character of the waters to be fished: whether open water or a small 70 


\section{The Trout}

brushy stream. Good rods can be obtained running from nine to eleven feet and from four to seven ounces. For narrow, shallow streams overhung with trees and shrubbery, and where the fish are small, the lightest and shortest rod is sufficient and most convenient. For larger streams or open water the rod should not exceed ten feet, and six ounces. Where trout are exceptionally large, as in the Lake Superior region or in Maine, the maximum of eleven feet, and seven ounces will be about right for most anglers.

Fly-rods built for tournament work, especially for long-distance casting, are marvels in their way, but it does not follow that they are adapted, or the best, for work on the stream. The essential and most important office of a rod is that which is exhibited after a fish is hooked-in other words, in the playing and landing of the fish. In practical angling the act of casting, either with fly or bait, is merely preliminary and subordinate to the real uses of a rod. The poorest fly-rod made will cast a fly thirty

The Chief Function of a Rod 


\section{Favorite Fish and Fishing}

or forty feet, which is about as far as called for in ordinary angling. But it is the continuous spring and yielding resistance of the bent rod, constantly maintained, that not only tires out the fish, but protects the weak snell or leader from breakage, and prevents a weak hold of the hook from giving way; and this is the proper function of a rod.

Reel, Line and Leader

The reel should be a single-action click reel, the lighter the better, if well made. The best, and in fact the only, line for flyfishing, is one of enameled silk, its caliber corresponding with the weight of the rod. Only the best quality of silk rorm fiber should be purchased in leaders for sizable fish. A leader of six feet is long encugh for three flies, and one of four feet with two flies is still better.

Artifial Flies

The subject of artificial flies is a most complex one. All fly-fishers have their favorites, with or without reason, and swear by then on all occasions. Some confine themselves to the various hackles, others to half-a-dozen winged Hies, while still 


\section{The Trout}

others are only satisfied with a fly-book filled to bursting with scores of all sizes and colors. In this connection it is as well to say that about the beginning of the century there was a discussion in the London Fishing Gazette as to what artificial fly, in case an angler was restricted to a single one, would be preferred for use during an entire season. The consensus of opinion was in favor of the "March brown," with the "olive dun" as a good second. These are both killing flies in America as well as in England for trout fishing.

In addition to them the coachman, professor, Montreal, dotterel or yellow dun, Selection of with the black, brown, red and gray hackles Flies should be sufficient on almost any stream, if tied in several sizes, say on hooks Nos. 6 to I 2 , with a preference for the intermediate numbers. From my experience I would be satisfied with such an assortment. Other anglers, of course, would think otherwise, and would prefer quite a different selection-but this is in accordance with one of the accepted and acknowledged privileges 


\section{Favorite Fish and Fishing}

of the gentle art. And this, at the same time, is as it should be. One who has had more success with cert?in flies than with others, all things being equal, should pin his iaith to them. And this, moreover, explains why there is such an extensive list to choose from in the fly-tier's catalogue, which contains the preferences of many generations of fly-fishers.

Philosopby of

The question as to the best $\mathrm{fly}$ to use at Artificial Flies certain seasons, or at any season, is a vexed one. Whether it is the colored dressing of the $\mathrm{fly}$, or its form, that is most enticing to the fish, will perhaps never be known, except approximately. Of the long list of named artificial flies the choice of most anglers has been narrowed to a score or two, and for the only reason that they have been more or less success ful with them. We are apt to look at the matter from our own viewpoint, and often without reference to that of the fish.

Reasoning from the appearance of artificial Hies in general, it would seem that on a fretted surface almost any one of the 


\section{The $\operatorname{Tr}$ t}

many hundreds should get a rise from a fish, if in a biting mood, and, indeed, this is in a measure true. But one swallow does not make a summer. There are times and places when any old thing, even a bit of colored rag, will coax a rise. I have had good success with a bit of the skin of a chicken neck with a feather or two attached. Then there arc times when nothing but natural bait proves alluring.

We may assume as almost a self-evident proposition that a fish takes an artificial $\mathrm{Hy}$. under the delusion that it is a natural one, or something gond to eat-otherwise it would not take it at all. If this assumption is correct, then it would follow that the best imitations of natural flies or insects should be the most successful. This is, in the main, a reascnable conclusion, though on the other hand certain flies that are universally considered and used as goo: ones, do not, to our eyes at least, bear any resemblance to any known insect-fo: instance the coachman, professor and other so-cailed fancy flies. 


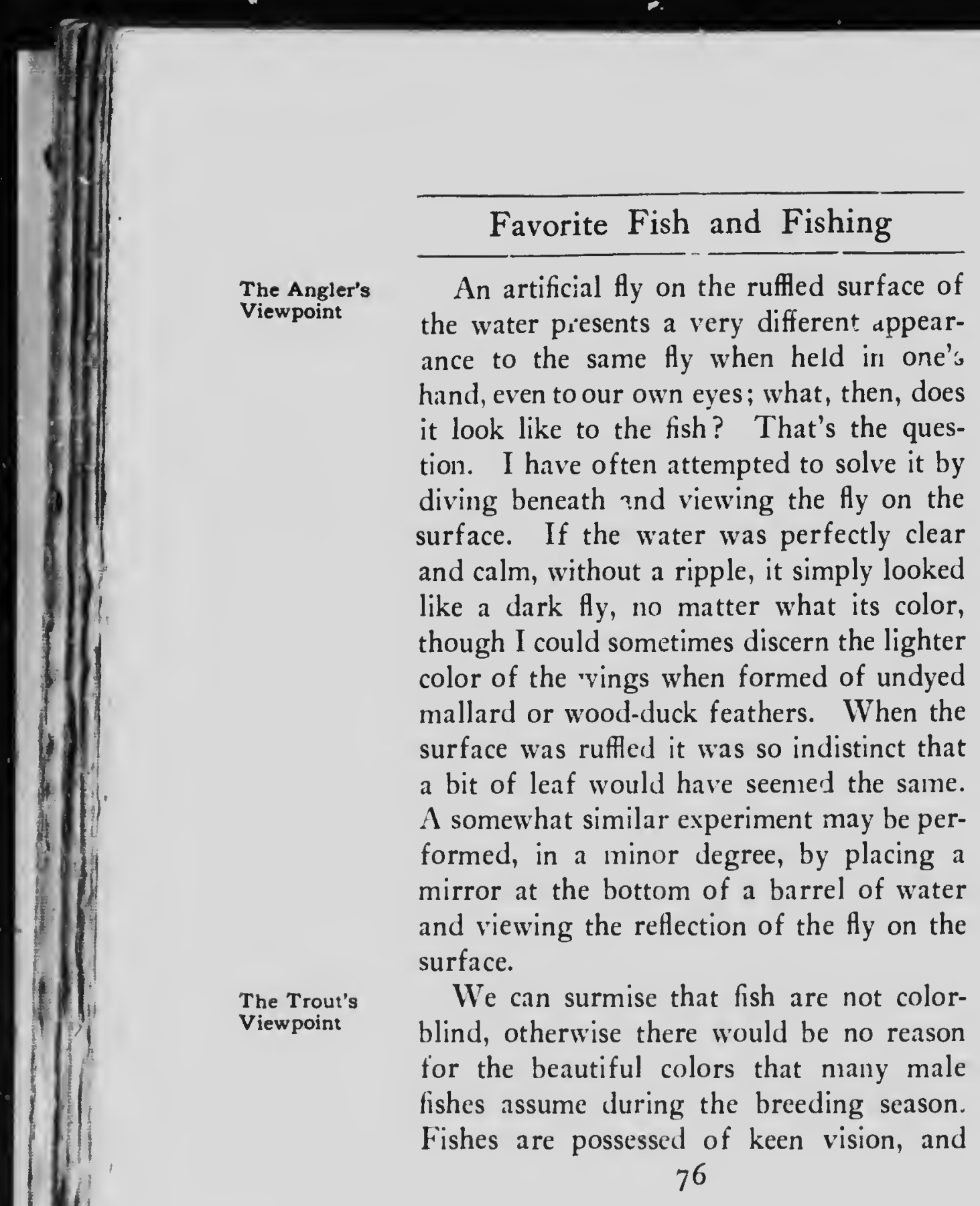




\section{The Trout}

possibly have the faculty of distinguishing colors in a fly, even when on a fretted surface, where to our eyes they are very indistirct, and where even the form can not be well defined.

In Griat Britain it is the rule to use certain flies ai different seasons, that is, to Flies in their employ the initations of such natural flies as are on the water at the time. This seems quite reasonable in view of the act that the trout streams there are shallow, and especially so in the case of the chalk-streams whose bright colored bottoms may enhance the visual powers of the fish in discerning, by the reflected light the form and colors of the artificial fly.

We may conclinde, then, that as trout are in the habit of $f$ fing on such flies and insects as resort to, or are hatched in, the water, that the best imitations of such natural flies, from the trout's viewpoint, would be the most alluring. I think it goes without saying, that all past experience has proven that the imitations of some of the commonest aquatic insects have been the 
Dark or Light Colored Flies
Favorite Fish and Fishing

most successful under all conditions. This would include not only the imago, but ti:e larva, as represented by the various hackle flies.

The old rule to use light-colored fles on dark days and high or discolored water, and darker flies on bright days, or with low and clea $r$ water, has been followed for centuries, and in the main is true and reliable. As some anglers have found that a reversed application of it has been successful, at times, they are inclined to doubt it altogether. However, they do not look at it intelligently. With clear water and a clear atmosphere a light-colored fly will show as plainly on the surface as a dark one to the fish below. If we gaze upward during a fall of snow, the flakes appear quite dark, while on a level or below the eye they appear white. Apparently, ihen, there are other conditions that must be taken into account. With a sunken fly, for instance, the case is different, for a dark Hy then appears more distinct than a light one, in clear water; but with milky or discolored water 78 


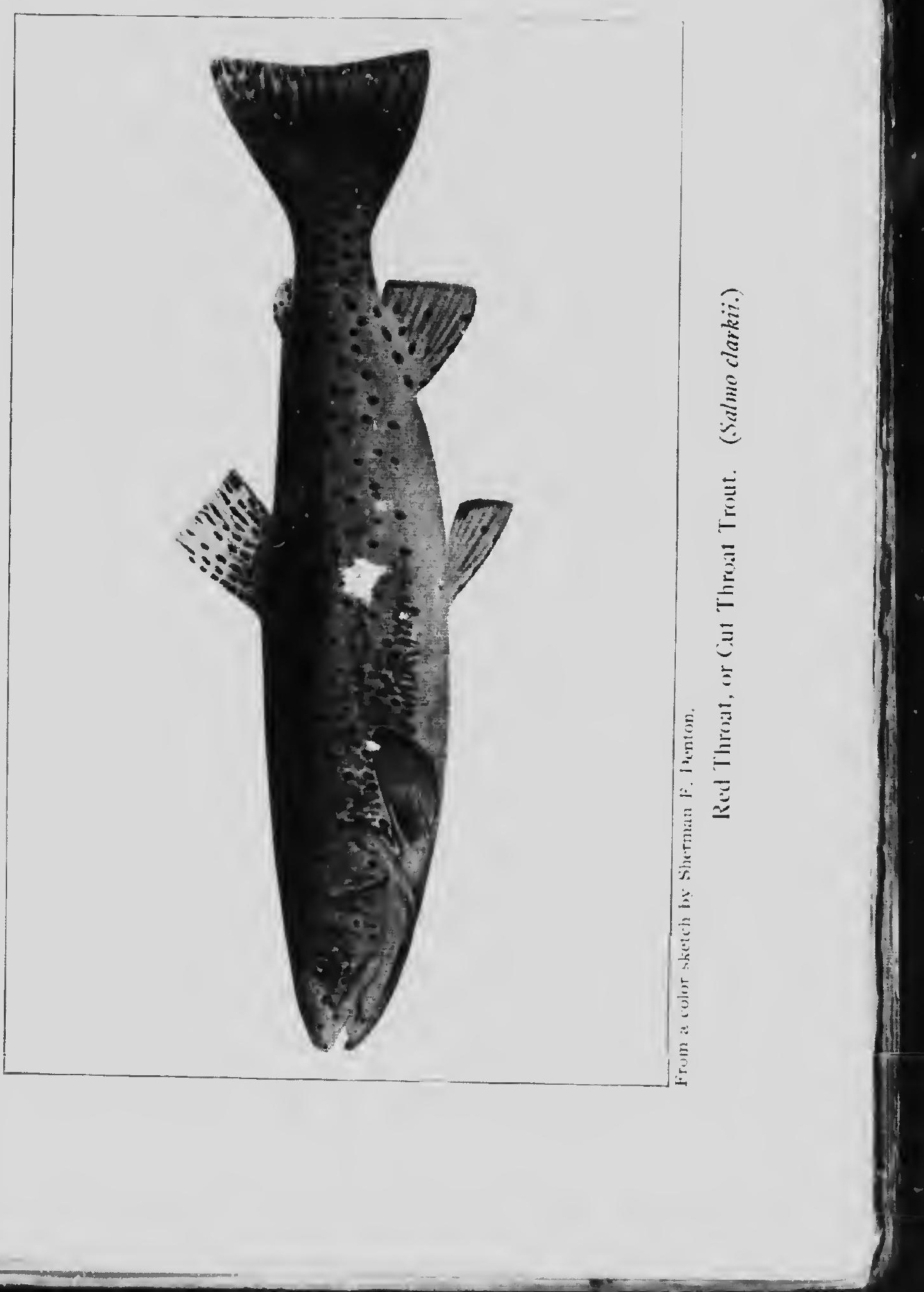




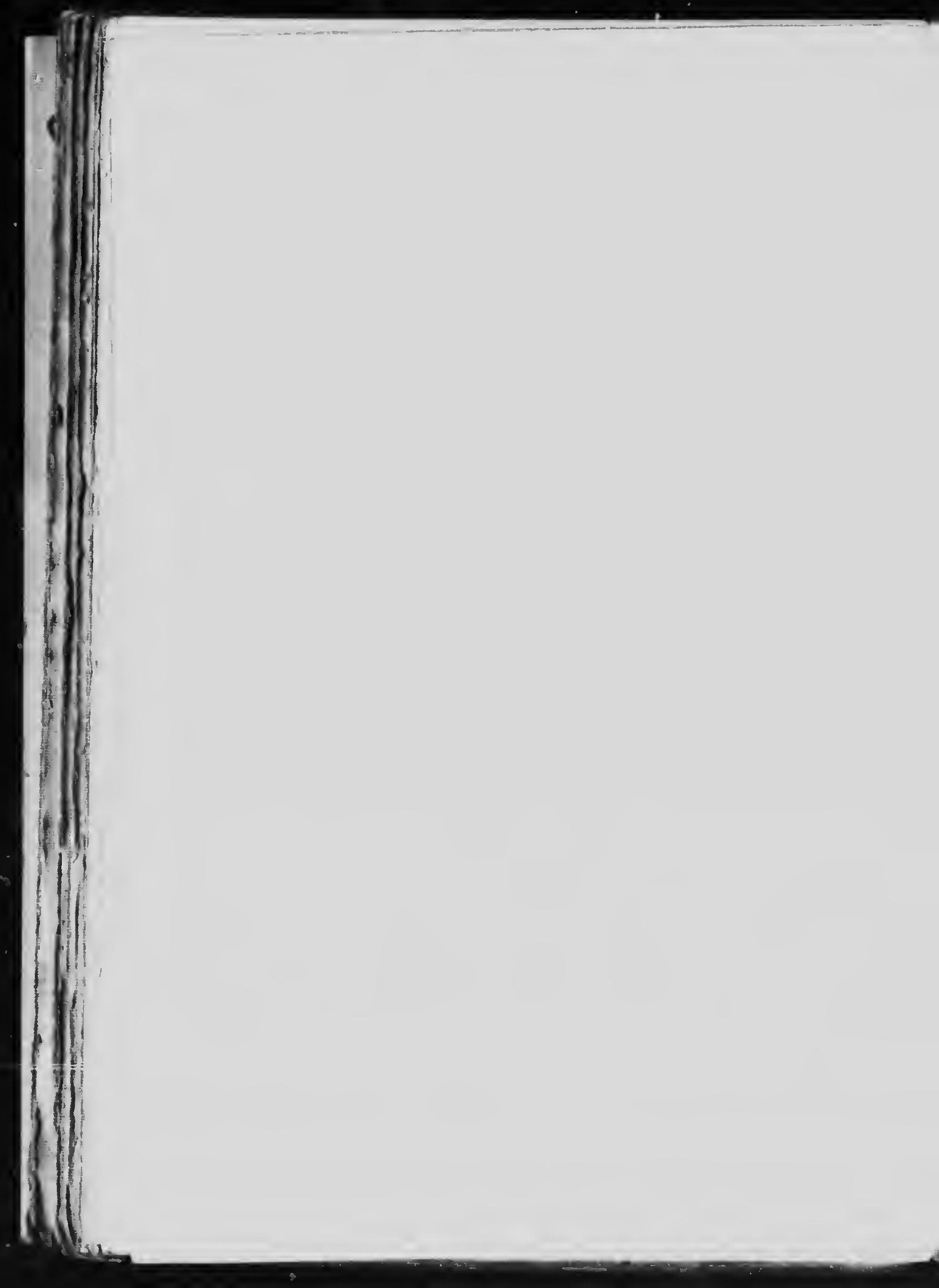




\section{The Trout}

a bright fly is more easily discerned below the surface-hence the rule. And on the same principle smaller flies are suitable for bright days and clear water, and larger unes for dark days and ciiscolored water.

In a very interesting address delivered before the Anglers Club, of Glasgow, ScotThe Non-Rising land, on "Why do trout sometimes not rise to the artificial fly?" the lecturer after naming and discussing many of the reasons usually advanced, said:

"And what is the conclusion of the whole matter? Shortly, this-that there is a great deal about the question that we know little or nothing about."

$\mathrm{He}$ advised his brother anglers to "Watch narrowly the facts as observed in nature, note them down carefully at the time, compare them with those of brother anglers on occasions such as this, and out of all evolve theories whirt wen reduced to practice, will be foun : ave carried us nearer to the truth."

This is very good advice freely givenand by the way advice is more easily givon

Condition

Versus Theory 
A Probable Reason

\section{Favorite Fish and Fishing}

than reliable information in a case like this. Nevertheless fly-fishers should consider that a "condition, not a theory," confronts them in the rising or non-rising of a trout to an artificial $\mathrm{fly}$, and should endeavor to ascertain, if such be possible, just what conditions are present to account for the peculiar actions, at different times, of those elusive creatures of the adipose fin, that according to popular opinion seem to have as many moods as specks or spots.

There is one feature of this subject, however, that I have never known to $\therefore$ alluded to, which is this: That the rising or nonrising of trout may depend on the scarcity or abundance of the fish. In regions where trout are unusually abundant I have never, in my experience, known them to fail to rise to the artificial fly, at any time of day, or under almost any condition of wind or weather. It is only in sections that are much fished, and fish consequently scarce, or " educated," as some term it for want of a better reason, that trout fail to respond to the solicitations of the fly-fisher.

80 



\section{The Trout}

In the wilds of Canada I have had trout Abundance of rise to my fly by the dozen, day after day, Trout so that all semblance of sport disappeared, and only enough were taken for the fryingpan. In Yellowstone Lake the merest tyro can take the red-throat trout until his arms ache, at any time of day, beneath clouds or sunshine. And in the river below the lake one can stand on the bank in plain sight of the trout, which, with one eye on the angler and the other on the fly, rushes to his doom by snapping up the tinseled lure, contrary to all conventional lore. This is an extreme case, of course, for the trout are extremely abundant, or were so as late as the suinmer of 1904 . One can imagine that in the clear and Scarcity of shallow streams of England, which have been thrashed by the flies of anglers, good, bad and indifferent, for centuries, and where trout are consequently and necessarily scarce, or " educated," that they fail to rise-in other words they are not always there. 'This, I think, is the reason that dry fly-fishing is becoming the vogue in that 


\section{Favorite Fish and Fishing}

country, where the angler waits patiently by the stream until a trout rising to a natural fly proclaims its presence. The rest is easy.

For obvious reasons it is always best to fish down stream where there is a current; in comparatively still water one may fish up-stream or down. I would advise the angler, by all means, to wade, as he has more command of the water on either hand, with plenty of room for the back cast, and can float his Hics under overhanging bushes and banks, or in the eddies of rocks. As the water is cold at this season he should be warmly clad, putting on two pairs of woolen socks or stockings, with rubber hip boots or wading pants. He should move slowly and cautiously, fishing every available spot before adrancing a step. By hurrying along as some angrlers do, he soon gets heated. even in cool weather, with the result that his nether extremities are soon bathed in a more or less profuse perspiration, and he is altogether a "dem'd. damp, moist, unpleasant body." To make haste slowly is the wise and proper thing in wad- 


\section{The Trout}

ing a stream. It is the slow, deliberate angler who gets the trout.

Some streams are likely to be occasionally swollen or roiled by spring rains or by the June rise. At such times, when not too much discolored for fly-fishing, the angler will do well to avoid the channel of the stream and cast his flies along the cdges, where the water is clearer. This tip may add many a fish to an othur wise scanty creel.

When the stream is at its ordinary stage, and clear, the riffles and eddies are the most likely places at this season, and will be pretty sure to reward the careful angler. In fishing such places the flies should be floated over them, allowing them to sink below the surface occasionally. In addition to the flics mentioned for May, the stone fly, gray drake and brown drake will be found useful, especially in localities where the May-fly or sand-fly puts in an appearance. During the hottest days of summer, when the water is warmer, trout are more apt to be found at the mouths of small

A Timely Tip

Likely Places 


\section{Favorite Fish and Fishing}

Management of Flies

Lowering the Tip spring brooks, or in the deepest portions of the stream.

Churning the flies up and down, or wiggling and dancing them, should be avoided; the only motion, if any, should be a very slight fluttering, ich as a drowning insect might make as it floats down stream. Strike lightly. Should the trout leap after being hooked, $a s$ it sometimes does in the shallow water of riftles, lower the tip slightly for half a second, but recover it immediately-in other words it is simply a down and up movement about as quickly as it can be done.

And talking of lowering the tip-it may not seem out of place to make a few observations concerning that procecding which some anglers do not seem to understand. or at least do not fully appreciate. The rulc of lowering the tip to a leaping fish is a rery old one, centuries old in fact, and is founded on the expericnce of anglers for many generations past. Its usefulness and reasonableness is as manifest in the twentieth century as at any former time.

84 


\section{The Trout}

But because some thoughtless anglers at the present day have succeeded in landing a leaping and well-hooked fish without observing the rule, they decry it as entirely unnecessary, and declare that it ought to be relegated to the limbo of obsnlete and fanciful notions and useless practices. The iconoclast usually attacks his images without thought or reason, and often in sheer ignorance. A little reflection might enlighten him and cause him to stay his hand.

The rule originated in Great Britain and pertained particularly to Ay-fishing. The

Origin of the Rule very small hooks on which trout flies were tied offered but at slight hold on the mouth of the fish, and in case that a leaping . i. threw its weight on a taut line and raised rod it was almost sure to break awayhence the rule to lower the tip and release the tersion for a brief moment. Is the fish regained the water the tip was raised and the former tension resumed. It must be unde " sod, however, that "lowering the tip " does not mean to touch the water with the tip, but as the rod is usually held at an 
Favorite Fish and Fishing

They Who

\section{Differ}

Long and Short

Line

Dry Fly-Fishing

angle of forty-five degrees, a downward deflection of the tip for a foot will usually suffice.

So far as my observation goes the objections to the rule have been raised by black bass bait-fishers who use heavy rods, strong tackle and large hooks. Under these circumstances a fish is usually so securely hooked by a vigorous yank that the lowering of the tip, when it leaps from the water, is not so essential, inasmuch as the angler has a cinch on his quarry whether the line be slack or taut.

But even in bait-fishing, with a light rod and corresponding tackle and a small hook, it is a wise plan to follow a leaping fish back to the water by slightly lowering the tip, especially on a short line-with a long line it does not matter so much, as the "give" of a pliant rod and long line is usually sufficient to relieve the increased tension when a fish is in the air.

Dry $\mathrm{Al}$-fishing is the latest angling cult in England, but I do not think that it will find many adherents in this country. For 


\section{The Trout}

one reason, the dry fly must be cast upstream, which will never be a favorite method with American anglers for wellknown reasons. Then again, our trout streams are usually swift and broken, and under these conditions the dry $\mathrm{fly}$ is soon drowned and becomes a wet fly, thus subverting the cardinal principle of dry flyfishing. In England this method is practiced on comparatively smooth, shallow streams with but little current. The flies are constructed with rather large, upright wings and spreading hackle, and of ten with cork bodies, to enhance their capacity for Hoating and buoyancy.

While fly-fishing, wet or dry, is unquestionably the highest branch of angling, and Comparisons far preferable to bait-fishing for trout, it does not follow that fishing with the dry $\mathrm{Hy}$, or Hoating $\mathrm{Aly}$, is a superior art to fishing with the wet or sunken fly, as claimed by some of the dry $A_{y}$-fishers of England. Indeed, some of the ultra dry Ay enthusiasts have arrogated to themselves the distinction of practicing the most artistic 


\section{Favorite Fish and Fishing}

and sportsmanlike method of angling, and look askance, if not with disdain and contempt, at the wet fly-fishers, whom they designate as the "chuck and chance it" sort.

I can not think that the position they have assumed can be justly maintained, or that it is warranted by the facts of the case. As dry fy-fishing is being taken up by a few American anglers, it may be well enough to give the alleged superiority of the method some consideration.

Modus

Operandi

Some years ago the modus operandi of dry fly-fishing was explained to me, personally, by Mr. William Senior, editor of the London Field. The angler waits beside the swim until a trout betrays its whereabouts by rising to a newly hatched gnat or fly, creating a dimple on the surface. The angler then, kneeling on one knee, sometimes having a knee-pad strapped on, cautiously casts his floating May-fly, with cocked wings, and anointed with paraffin or vaseline. The fly is deftly and lightly cast up-stream, a little above the swirl of the trout, and is permitted to Hoat down, ?s 88 


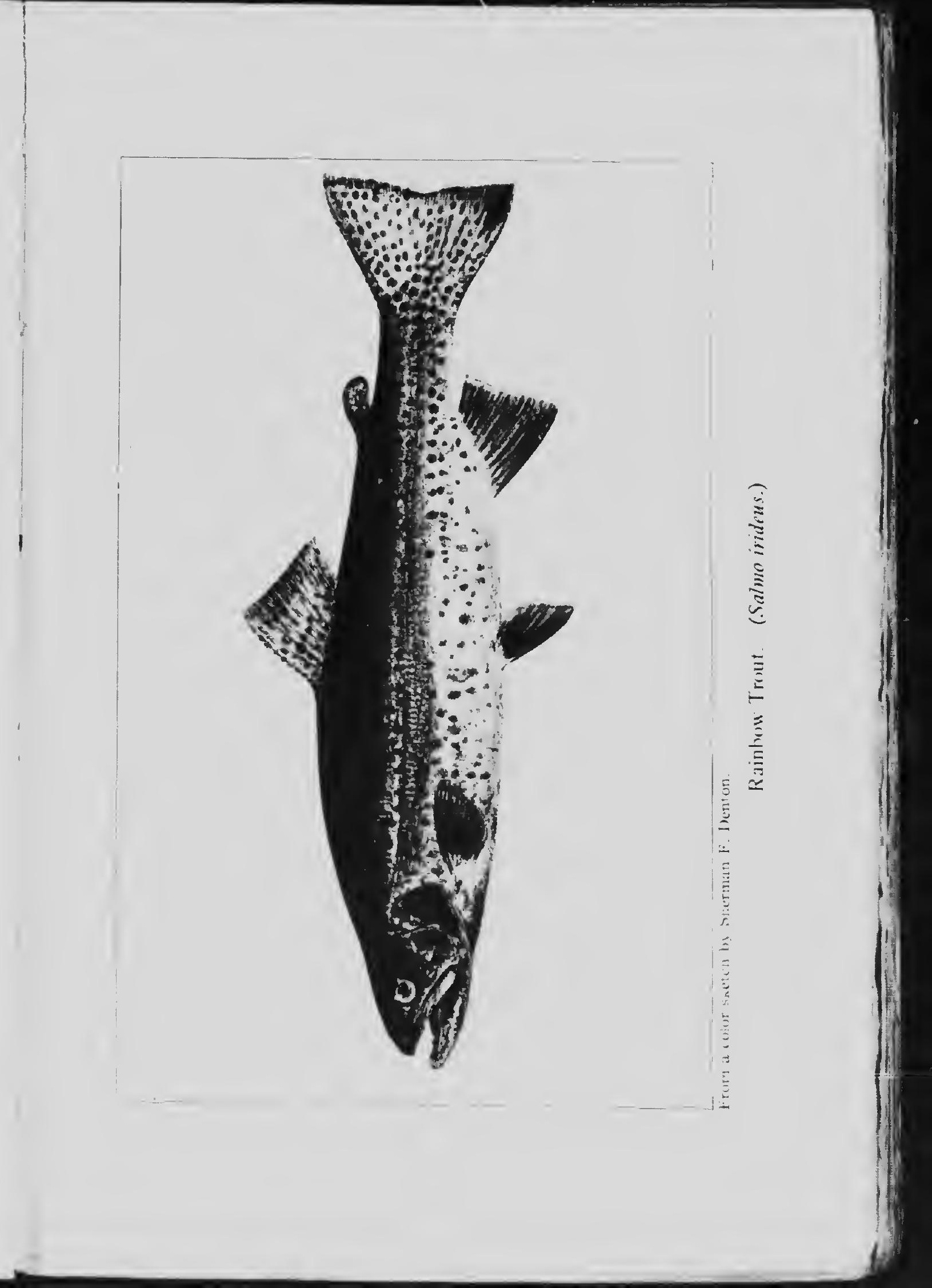




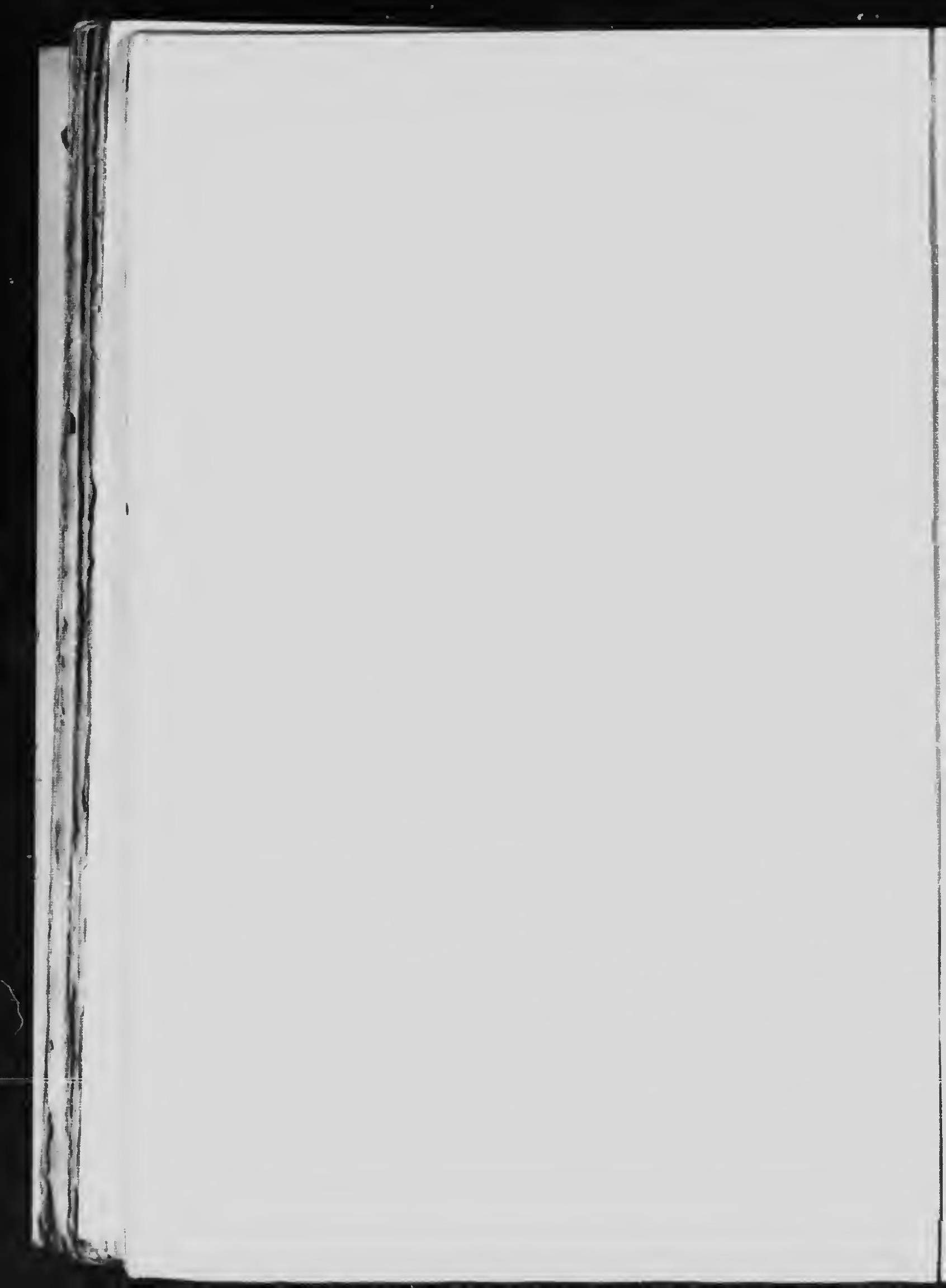




\section{Tlie Trout}

naturally as possible, over the fish. There being no response after a cast or two, the angler switches the fly in the air to dry it, and awaits the tell-tale evidence of a fish before again offering the buoyant lure. Now, I cannot imagine why this method is claimed to be on a higher plane of angling than the "chuck and chance it" method. Certainly a knowledge of the habits of the trout is not essential, inasmuch as the angler makes his cast only on the appearance of the fish.

On the other hand the wet fly-fisher, wading down strean or up stream, brings to his The Wet FlyFisher aid his knowledge of the habits and haunts of the trout, and casts his flies over every likely spot where his experience leads him to think a fish may lie. It is this eager expectancy, or fond anticipation, with every cast, that makes up much of the real pleasure of angling, and which is utterly lost to the dry fly-fisher, who waits and watches on t'. Bank, like a kingfisher on his perch.

While there can be no objection to dry fly-fishing, per se, and which, moreover, I 


\section{Favorite Fish and Fishing}

welcome as a pleasing and meritorious innovation, I feel compelled to enter a protest against claiming for it a higher niche in the ethics of sport than wet Hy-fishing. And with all due respect for the dry fly men of Great Britain, I can not admit that they trot in a higher class than those " chuck and chance it" fishers of honored and revered memory: Sir Humphry Davy, "Christopher North" and Francis Francis.

\section{Bait Fishing}

It is the practice of some anglers to confine themselves entirely to natural bait in trout fishing, the favorite bait being the earthworm or "barnyard hackle"; also grasshoppers, grubs, crickets, or bits of animal flesh. While not so artistic, or for that matter not so successful as Hy-fishing when the streams are clear, there are times when bait-fishing can be practiced without prejudice, and to better advantage than flyfishing: as when streams are rendered turbid or roily by rains.

A capital bait is the beautifully tinted anal fin of a trout, which in water with some current waves, wabbles and flutters in 


\section{The Trout}

a most seductive manner on the hook. Its effect is heightened, and its resemblance to a living insect is more pronounced, if the eye of a trout is first impaled on the hook through its enveloping membrane, care being taken not to puncture the eyeball.

I was once fishing with fin-bait in Wis- A Fish Story consin, early in the season when the stream was milky, when one trout was badly hooked, the point of the hook forcing out the eyeball, which hung on its cheek. I carefully unhooked the fish and plucked off the eye, when the unfortunate trout flopped out of my hand into the stream before I could kill it. I added the eycball to my finbait, and strange to say I soon caught the same trout with its own eye! While this story may be more difficult for the uninitiated to swallow than for the trout to bolt its own eye, it is nevertheless true, and may be taken as proof that fish are not very sensitive to pain.

The equipment recommended for fly- Tools and fishing will answer just as well for baitfishing, as the baits commonly used are 


\section{Favorite Fish and Fishing}

light. $\ln$ some instances, however, a slightly heavier or stiffer rod may be employed, especially if the small casting-spoon or a small minnow is used for large trout. Hooks from Nos. 5 to 7 are about right.

The Sea Trout

Whether the sea-trout, or salmon-trout, of the Gulf of St. Lawrence is a different species from the speckled brook trout of the upper parts of rivers emptying into said Gulf has been a mooted question for many years, arguments pro and con having been advanced by a number of intelligent and observant anglers. In I $83+$ Hamilton Smith described it as a new species under the name of Salmo camadensis, and in I 850

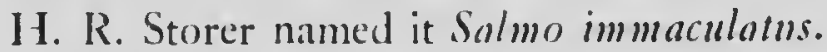
Later and better authorities, however, have decided that it is only a sea-run form of the speckled brook trout, Salielimms fontimalis. I unhesitatingly indorse this opinion. Many years ago Dr. W. W. Dawson and myself investigated the matter thoroughly while salmon fishing on the Restigouche River. About the Metapediac, and below the railroad bridge, we caught the brook trout with 


\section{The Trout}

its crimson and yellow spots, and near Campbellion, at the mouth of the river, we took the fresh-run form of bright silvery coloration, with scarcely any markings on the back and without spots. Wc also caught them a little higher up the river in transition stages, when the characteristic spots were beginning to appear, more or less pronounced. We compared hundreds, from plain silvery form to those with bright crimson and golden spots, but could find no structural differences.

Marine fishes are very constant in coloration, the non-colored portions being quite

Changes in silvery, while fishes of fresh waters are subColoration ject to frequent changes in hue, being much influenced in this respect by the character of their haunts. So when the brook trout "goes to sea" it loses its spots and takes on the silvery livery of marine fishes, but resumes its origimal coloration soon after entering fresh water.

Just why the winninish of the upper St. The Winninish Lawrence, which is but a dwarfed form of the Atlantic salmon, does not also proceed 


\section{Favorite Fish and Fishing}

to sea after the spawning season, like its prototype, is another puzzling proposition. It has been argued by some that the winninish is the original, or typical species, and that the anadromous salmon is descended from individuals that took on the seafaring habit. But such speculative theories can never be proven.

A Virgin Trout

Twenty years ago, Dr. W. W. Dawson, Stream of Cincinnati-then president of the American Medical Association-and myself were guests of Surgeon-General Baxter, U.S.A., at his fishing lodge near Metapedia, on the Restigouche River, New Brunswick. Twenty years ago! How time flies! Since then my dear friends, Doctors Dawson and Baxter, have both crossed the silent river, though it seems but a few weeks since we were casting our lines in the pleasant places on the famous Restigouche. Indecd, that pleasant summer seems as but yesterday. when Mrs. Baxter killed with her own rod six salmon, rumning from twenty to thirty pounds, and was not more than thirty minutes in bringing any of them to gaff. 


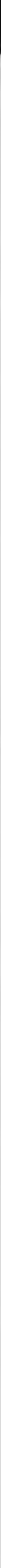




\section{The Trout}

One day at Campbellton, at the mouth of tise river, I met Mr. Dean Sage, of Albany, N. Y., who kindly gave me permission to fish his excellent waters, farther up the Restigouche. I also met there Mr. Light, Chief Engineer of the Dominion of Canada, who gave me such a glowing account of the trout streams that had jusi been rendered accessible by the Quehec and I ake St. John railway, that Dr. Dawson and myself gave up our contemplated trip to the Nipigon, and decided to gn up the Batiscan River in accordance with the advice of Mr. I. ight.

He recommended taking with us from the Restigouche two Gaspé cannes and The Batiscan River

canoemen who were accustomed to swift and rocky water; for the Batiscan, he informed us, contained numerous rapids that would tax the strength and prowess of the most experienced canoemen. We engaged two Restigouche men to accompany us, and decided to take but one Ciaspé wooden canoe, thirty feet long, and to procure a smaller and lighter one at Quebec. 


\section{Favorite Fish and Fishing}

In Old Quebec

Arriving at that quaint and historic town, we obtained, with the help of the American consul, Mr. Downes, a new basswood canoe, built on the model of a birch bark, about fifteen feet in length; this we procured from an Indian tribe near the city. Through our letter of introduction from Mr. Light to Mr. Beemer, the contractor of the Q. \& L. St. John railway, we had no difficulty in getting transportation for our canoes and camp equipage to the Batiscan River, which was then the terminus of the railway. Indeed, Mr. Beemer kindly went with us to that point, to see that we were started right on our exploration of the Lpper Batiscan. Our objective point was Batiscan Iake, some ten miles as the crow Hies, but the distance by river unknown, for its upper waters had never been ished by white men. A railroad survey party had gone a short distance up the stream by land, but beyond that it was a lerra incognita to the angler. I questioned an old French trapper, who told me that he had been to the lake with sled and snowshoes in winter, 


\section{The Trout}

and had fished through the ice; also that the trout ran up to ten pounds in weight. It was to be a veritable voyage of discovery, and Mr. Light was quite des:rous to know something of the resources and particulars of the region, having leased the fishing privileges from the Dominion.

Arriving at the river, I found M. Lacs du Rognon Farnsworth-who has written so entertainingly of the French inhabitants-established in a pleasant camp a mile below the railroad crossing. I also met Captain Seaton, president of a Quebec fishing club, the lessee of the Lacs du Rognon, near the railroad crossing of the Batiscan. Captain Seaton showed me a basket of brook trout averaging five pounds, but to my surprise he stated that they were taken with the trolling spoon, as the trout of those lakes-more's the pity-utterly refused to take the fly, giving as a reason that those waters abounded in myriads of chub, on which the trout habitually fed.

We embarked in the canoes and pro- Up the River ceeded up the river, which we found to be 


\section{Favorite Fish and Fishing}

a wild, rocky stream, with long rapias, up which it was impossible to propel the canoes. This entailed the labor and delay of long portages, making our progress extremely slow. Between the rapids were long stretches of smooth, but very rapid water. The mountains rose up on each side from the edge of the stream, so that the portages were on a side hill of Laurentian rocks overgrown with moss a foot or two in depth. Owing to these difficulties we were six days in traveling five miles, and failed to reach Batiscan Lake, though I saw its waters from the top of a mountain.

Trout Galore

That we found trout galore is no name for it. They were as numerous as the black flies by day or the mosquitoes by night. And the chub were both plentiful and gamy-great dark, round, stout fellows, weighing sometimes two pounds, and gamier than the trout. IVe at last reached a fall, or rather twin falls, aggregating some thirty feet in height, and the most beautiful sight I have ever seen on any stream. The summit of the fall Howed in $9^{8}$ 


\section{The Trout}

a straight, unbroken line across the river, over a solid ledge of rocks, with a curve as true, uniform, and unbroken as a mill dam. The waters fell into a circular basin of considerable extent, and then, divided by a small island in the middle of the lower fall, plunged down again to the lower level. On this little isle were twin fir trees of remarkable beauty and symmetry, standing like lent sentinels in the silent Canadian forest - for no sound was ever heard except the rushing of the tumultuous waters beneath. The absence of birds was remarkable, only Batiscan Falls an occasional song sparrow being heard.

Our last camp was at the summit of the fall, a few feet from its edge. Above the fall were nothing but brook trout; not a chub to be seen; great lusty trout from onehalf to three pounds-none less, none more. And they were too plentiful for real sport. A dozen would rise to the single fly at once, knocking it about sometimes like a tennis ball. We fished only a few minutes in the early morning and toward sundown, as we took only enough to supply the camp. 
Favorite Fish and Fishing

Fishing on the Verge
Lake Edward
Most of my fishing here was from the very verge or curve of the fall, where the trout were playing. Strange to say, none went over, as I ascertained by careful watching below. Indeed, there seemed to be none in the circular basin below. I could, at least, see none, neither cou'd ' get a rise, though I tried repeatedly. WVI 1 hooked, on the verge of the fall, the fish always started up stream. As there were two feet of water going over the fall with a velocity of five or six miles an hour, or more, the strength and activity of the trout can be imagined. These trout were the most beautiful and highly colored I have ever seen; their bellies a bright orange-red, and their sides sprinkled with gold and intensely crimson spots, and their fins edged with jet black and pure white. The coloration was unusually vivid and pronounced.

From this camp we could hear all day the workmen on the railroad blasting near Lake Edward, which was but a few miles away, and which has since become so noted as a fishing resort. 


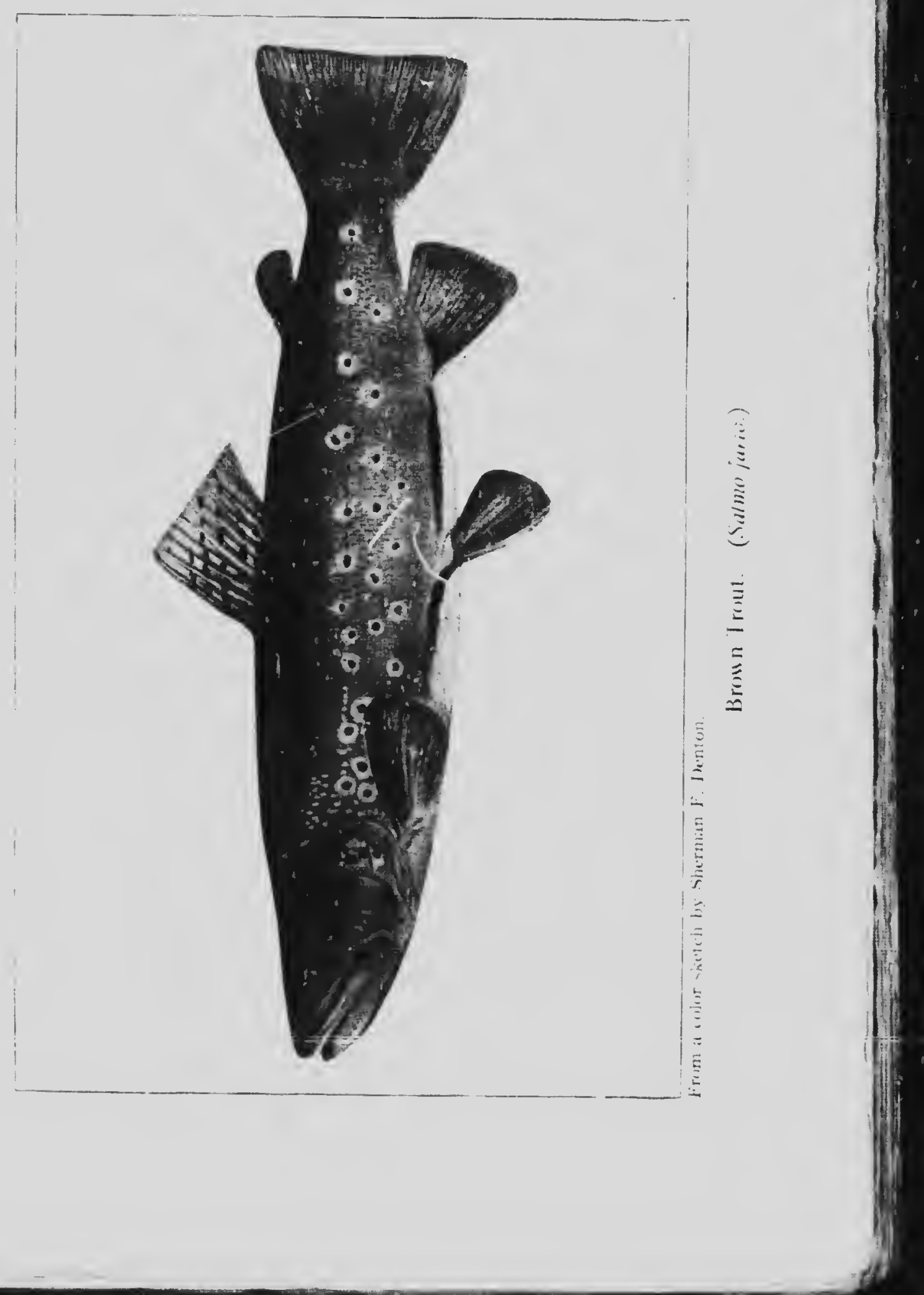




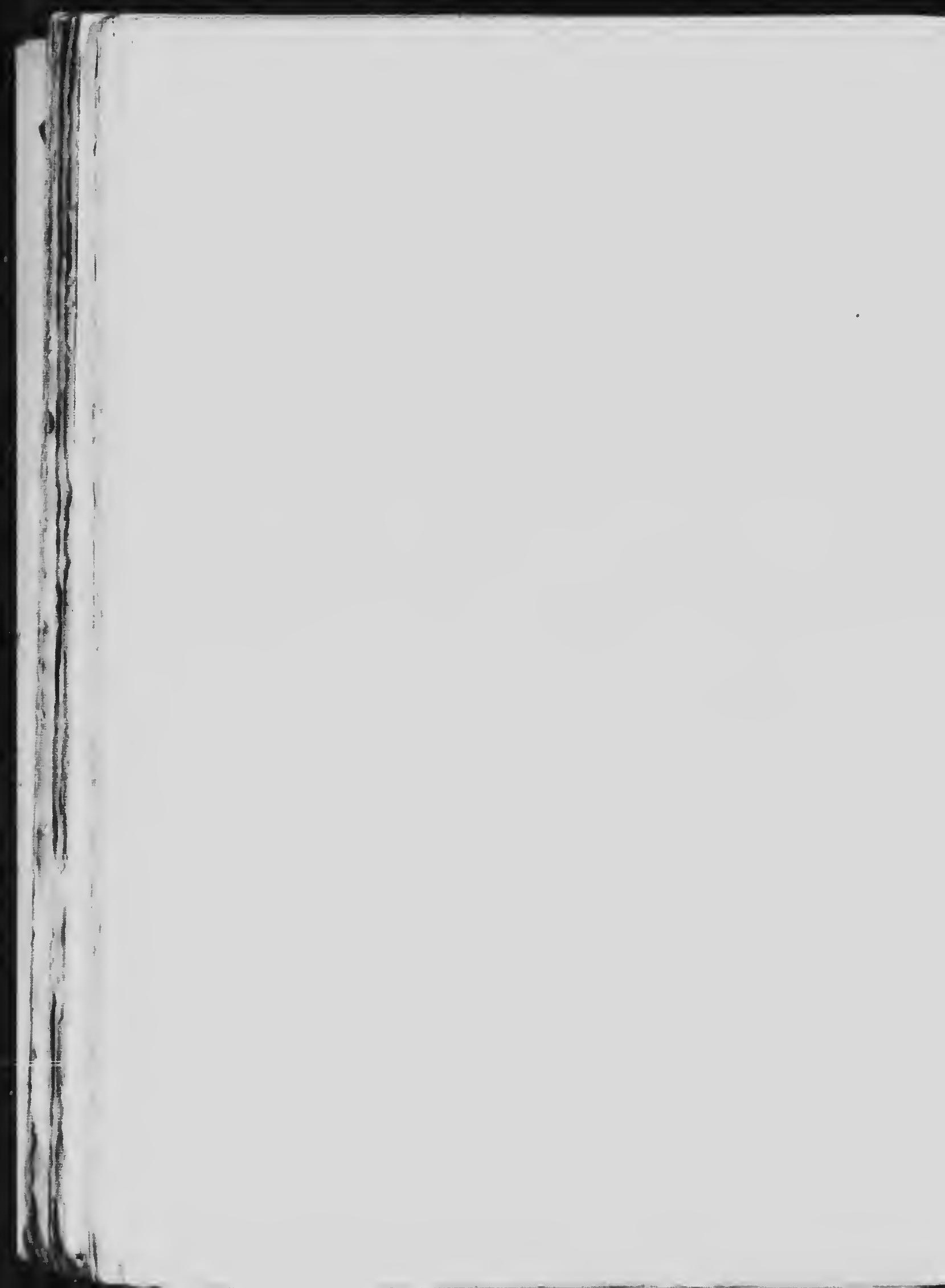




\section{The Trout}

ihis was, in truth, a virgin trout stream. No artificial tly had ever before fretted the surface of its pristine waters. The only sign of man was the mark on a tree, near our camp, where a chip had been cut out by a trapper, years before. Just above nur camp was a narrow trail leading from the cliffs $t$ (' the river, but the only tracks were those of caribou, be: : - ons, and porcu. pines.

There are other species of trout in There Are American waters that are fished for in much the same way as for brook trout; they are the rainbow, steelhead, red-throat, golden, Dolly Varden and Sunapee trout; also the introduced European brown trout. These various species are being introduced in trout waters in a number of states, so that it may be well to briefly refer to some of their characteristics.

In the Rocky Mountain region there are three groups of trout belonging to the Rocky Mountain Salmo genus-the steelhead, rainbow and red-throat, or cut-throat as it is sometimes called. They are all black spotted. In

\section{Species}




\section{Favorite Fish and Fishing}

widely separated sections of country these different species may be readily distinguished by certain characteristics, but in other localities, where they co-exist naturally, it is sometimes a difficult matter to distinguish one group from another. At one time, indeed, the rainbow and steelhead were pronounced by competent authority to be the same fish, the steelhead being supposed to be the sea-run form of the species. At the present time, however, they are held to be distinct species.

The Dolly Varden, or bull-trout, belongs to a different genus (Salcelinus), and is related to the brook trout of Eastern waters, having also red spots. While the red-throat trout inhabits both slopes of the Rockies, the others named belonged originally to the Pacific Slope.

The Red Throat Trout (Silmo clarkii)
The red-throat trout is the most widely distributed of the Western trouts. It inhabits both slopes of the Rocky Mountains, and, as might be inferred trom this extensive range, it varies in external appearance more than any of the trout species. There 102 


\section{The Trout}

are a dozen or more well-defined sub-species or geographical varieties, but all have the characteristic red splashes on the membrane of the throat. By means of this "trademark" it may be readily distinguished from the rainbow or steelhead trouts, both of which are also black-spotted.

But while the red-throat trout varies con- Nomenclature siderably in contour, coloration and markings, in different localities, it is identical in structure wherever found. It is known by the United States Bureau of Fisheries as the "black-spotted trout," a most unfortunate designation, inasmuch as the rainbow and steelhead trouts are also "black-spotted." The name red-throat is distinctive, and is preferable to the rather repulsive name of "cut-throat" trout by which it is also known. The red-throat trout is designated in its native waters by such names as " trout," "brook trout," "speckled mountain trout," etc. As the Eastern red-spotted "brook trcut" is rapidly being introduced to Western waters, the name "brook trout" should be applied only to that species.

I 03 


\section{Favorite Fish and Fishing}

Growth and Weight

Where the red-throat trout grows to a larger size than usual, as in the Yellowstone and other lakes, it is often called "salmon-trout," and the bull-trout of the sacific Slope is also sometimes known by the same name, but the only "salmontrout" is the steelhead trout. The redthroat trout rises to the fly more freely than the Eastern brook trout, though in gameness and flavor it is hardly its equal. Its habits are also somewhat different. It usually lies in pools and holes, and does not frequent the riffles so much as the Eastern trout. In size it is somewhat larger than the Eastern trout in streams of the same relative width and depth, and like all trout species grows to greater weight in lakes and large streams. I have taken them on the fly weighing from three to five pounds in Soda Butte Lake in the Yellowstone Park, and in Yankee Jim Cañon on the Yellowstone River. In Yel.owstone Lake some are infested with the white pelican parasite, rendering them emaciated and lacking in game qualities; this condition, 


\section{The Trout}

however, seems to be disappearing somewhat, while those in the river below are well-nourished and gamy.

The same tackle and artificial fies used Tools and for the Eastern brook trout are as suitable, Tackle as a rule, for the red-throat, though preference is given to the stone fly, coachman, professor, black gnat, cinnamon, Henshall, and the various hackles by Montana anglers. The red-throat seldom breaks water when hooked, but puts up a vigorous fight beneath the surface. As the mountain streams are usually swift and rocky and fringed with alders, willows and other small trees, the angler must be wide awake to land his fish and save his tackle.

The steelhead, or salmon-trout, is the trimmest and most graceful and the gamest of all the trout species, being more "salmon-like" in shape and appearance. On the Pacific Coast, where it is native, and runs to salt water, it grows to twenty pounds or more in weight, when it is known as steelhead salmon, and many are canned under this name. Its spots are smaller than

The Steelhead Trout (Salmo gairdneri)

$$
\text { I } 5
$$




\section{Favorite Fish and Fishing}

in the other black-spotted species. It has, sometimes, especially the males, a pink flush along the sides, but not so pronounced as in the rainbow trout. Its color is also of a lighter hue, with steely reflections. Its scales are somewhat larger than those of the red-throat, but not so large as in the rainbow trout.

As a Cume. Fish

It seems to be pretty well established in Lake Superior, where it was introduced by the United States Bureau of Fisheries, some fine catches having been made of late years. It has also been introduced into several states on the eastern slope of the Rockies, which seem to be very suitable for this fine fish. In Montana I have taken it up to five pounds. It rises eagerly to the fly, and when hooked breaks water repeatedly like the black bass. It is very trying to light tackle, and must be carefully handled by the angler. The flies named for the redthroat trout are just as killing lor the steelhead. I ike the red-throat it is also susceptible to bait, which in Montana is the "rock-worm," the larria of the caddis $\mathrm{Ay}$. I 06 


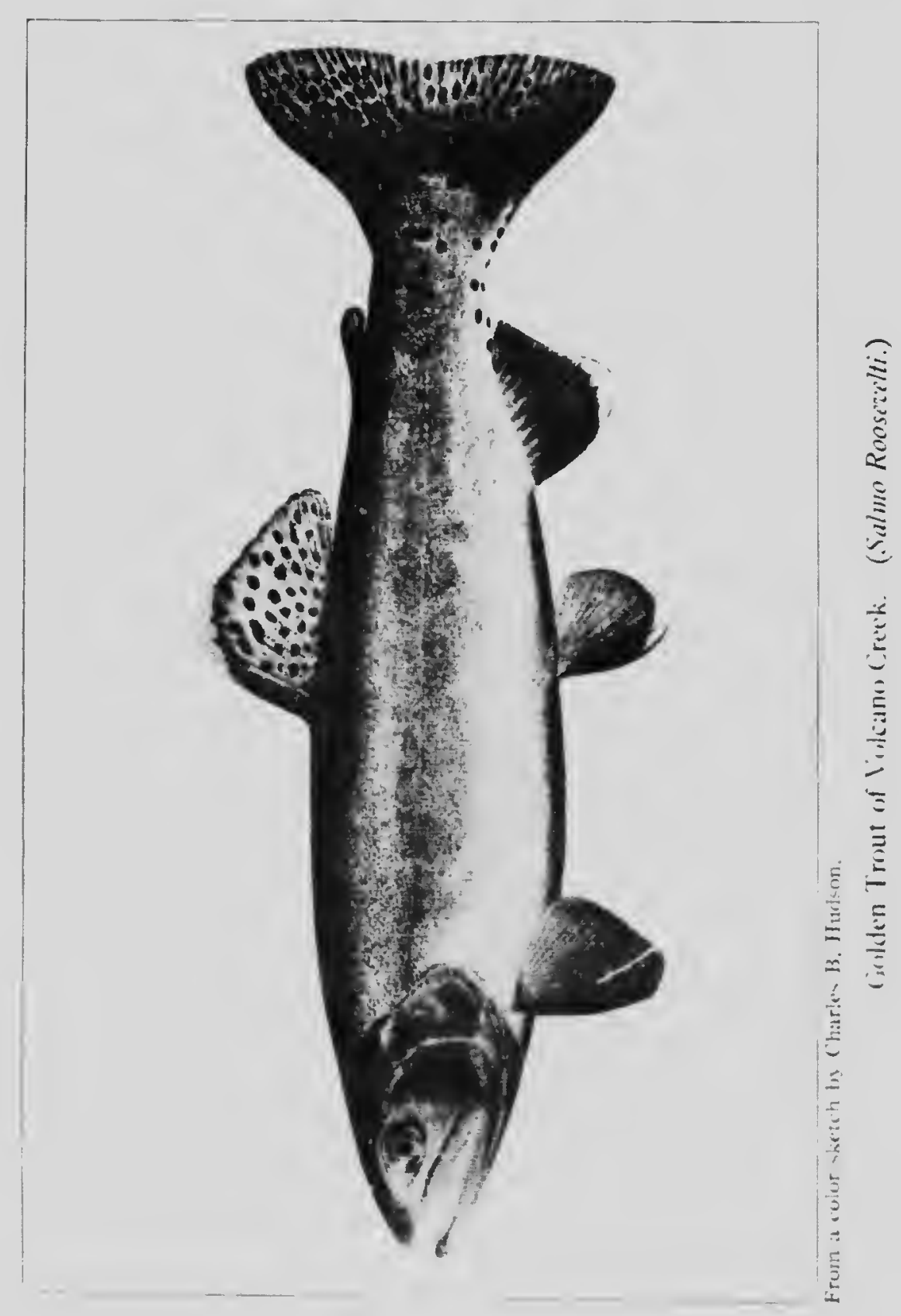




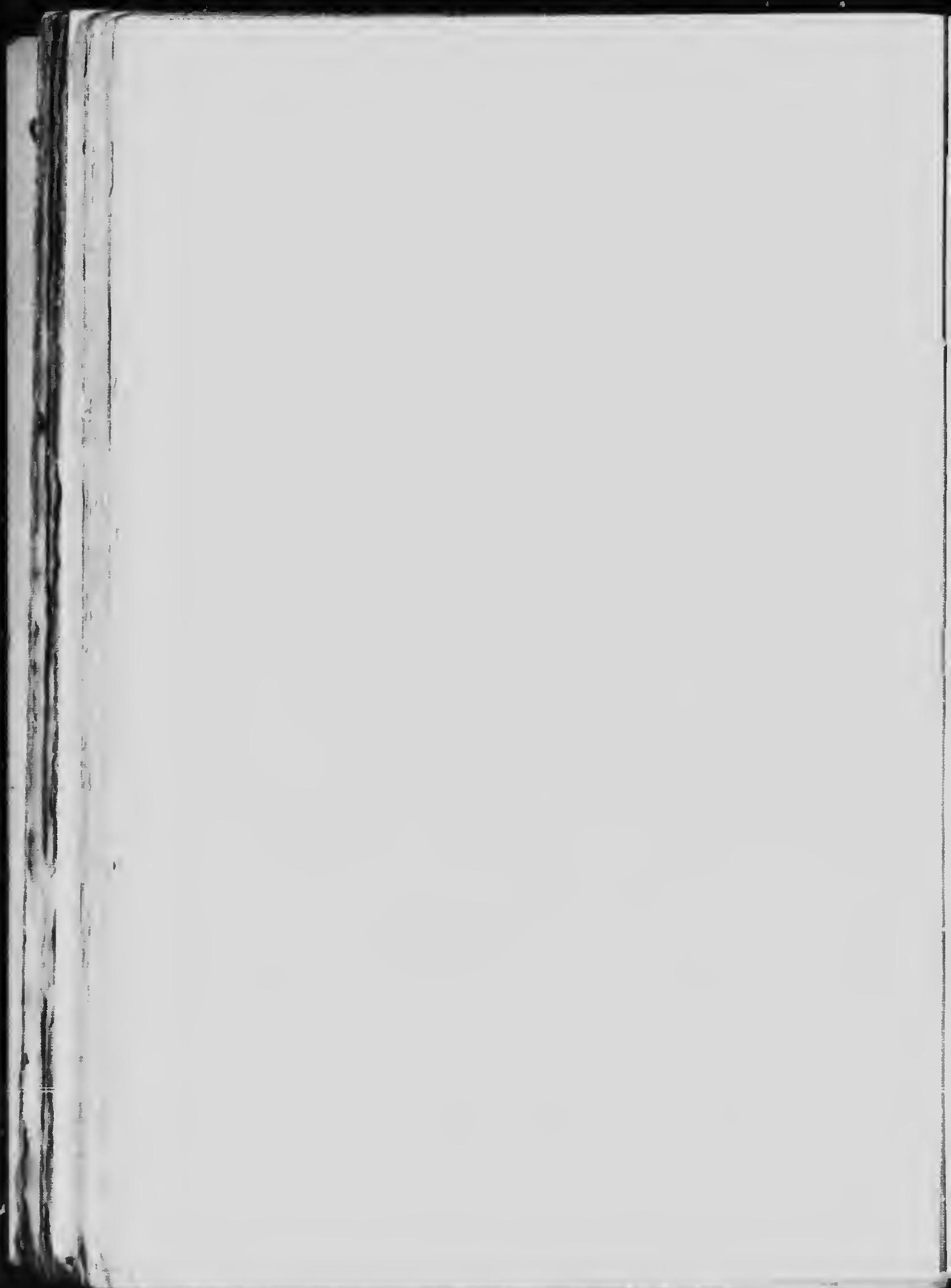




\section{The Trout}

As a food fish it excels all of the trout Remarkable species as might be surmised. In fresh Growth water lakes it should grow to eight or ten pounds. Vear Virginia City, Montana, is located fisolotl Lake, so named from being inhabited by a species of axolotl, but it contained no fish of any kind until stocked with a few thousand steelhead trout fingerlings from the Bozeman Fisheries Station, in 1902. In September, 1907, two of my friends, while trolling from a canvas boat on this lake, caught eleven trout weighing in the aggregate seventy pounds, the largest weighing thirteen pounds, an extraordinary weight for a five-year-old trout. But this is easily explained when it is considered that the trout had been feasting for several years on such nutritious diet as these curious amphibians afforded, and in great abundance, but which now are said to be scarce.

The rainbow trout has also been introduced to Eastern waters by the United States Bureau of Fisheries, and seems to be well adapted to ponds of considerable ex- 


\section{Favorite Fish and Fishing}

tent, where water plants and grasses flourish. Such waters seem to be more congenial than the colder mountain streams; and nıoreover it has a way of disappearing from the smaller streams to seek those of greater depth. It will thrive in warmer water than the other trouts. The rainbow is similar in contour to the red-throat, though somewhat deeper, and with shorter head, smaller mouth, and larger scales. Its distinguishing feature is the broad red band along the lateral line, common to both male and female. It is a handsome fish, with considerably more gameness than the redthroat, but is not so vigorous on the rod as the steelhead of the same size. Owing to its tendency to descend streams it is particularly liabie to enter irrigation ditches, in which event its doom is sealed. As a foodfish it is superior to the native red-throat trout.

In New Waters

In no new waters has the rainbow done so well as in those of Michigan and Colorado. In the former state it has populated streams that were once the home of the grayling, I08 


\section{The Trout}

more's the pity. In Colırado, in the Gunnison and neighboring streams, it furnishes sport galore to hundreds of delighted anglers, who visit the locality especially for the fine fishing. No trout surpasses the rainbow in rising to the artificial $\mathrm{Hy}$, and almost any trout fly will capture it, though the silver doctor, coachman, and the different hackles, seem to be more favored than others.

The Dolly Varden, or bull-trout, some- The Dolly times erroneously called " salmon-trout," is the only red-spotted trout native to IVestern Varden Trout (Salvelinus waters. It belongs to the same genus as the lastern brook trout, but grows much larger. It is found only on the Pacific Slope, in both lakes and streams, growing to twelve or fifteen pounds under favorable conditions. In the streans it is a gamer fish than in lakes, though the larger fish are rather lazy and logy. Compared with its Eastern relative it is hardly so vigorous on the rod, when of similar weight, and not quite so good for the table.

It takes the fly readily, also any kind of I 09 


\section{Favorite Fish and Fishing}

The Brown

Trout (Salmo fario) natural bait, and in lakes or broad streams succumbs to the trolling-spoon. It is not so great a favorite as the other Western trouts, except in Alaska, where it is abundar . in all lakes and streams.

The brown trout is the brook trout of Europe, and was introduced to the United States from England and Germany, under the auspices of the Unitr? Jtates Bureau of Fisheries. Those fr a Germany (the eggs), were donated by Von Behr, and his name was unfortunately applied to the fish as "Von Behr trout," also "German trout," two most unfortunate and ridiculous names. It is the "brook trout " of Europe and "brown trout" of Great Britain. In Germany it is "bach forelle," which means brook trout. Among English-speaking people it has been known since before the day of Walton and Cotton as "brown trout," and brown trout it should be world without end. To rob this fine fish of its good name and substitute the misnomers mentioned was both unwise and absurd.

I sincerely hope that those names, toI IO 


\section{The Trout}

gether with the equally absurd name of Absurd Names " black-spotted trout," as applied to the redthroat trout, will soon be relegated to the shades of oblivion, never to be mentioned in polite angling society. If the fish mentioned was the only black-spotted trout inhabiting its native waters, it would be a good and suitable name, but unfortunately its congeners, the rainbow and steelhead trouts, are also "black-spotted" as before mentioned. The name originated, I think, about the same time as "Von Behr." When the first eggs were taken East and hatched the fry were called Rocky Mountain trout and California trout, the former name being more applicable than the latter, but neither were very suitable. Our technical knowledge of the Western trouts must have been sadly deficient, however, when they were displaced for "black-spotted trout."

The brown trout has both reddish-brown and black spots, of a larger size than those As a Game- and Food-Fish of its American cousins. Altogether it is a fine fish, much prized in Great Britain, 
Favorite Fish and Fishing

but in American waters it is hardly so gamy, and not quite so good a food-fish as our native trouts. It grows to a larger size than our brook trout, and will thrive in warmer water. A variety of the brown trout, the Loch Leven, was introduced into Firehole River, in the Yellowstone National Park, some years ago, and it is remarkable how well they thrive in the warm geyser water. They must have been plante in some st eam in the Park tributary to the Yellowstone River also, for I knw of two being taken near Livingston, $\mathrm{M}$ ntana.

weighing more than ten pounds, the oth: $r$ about twelve. In a pond nor Bozeman. Montana, some brown trout fry were planted, and at the end of four vears two were taken weighing six pounds ... h, both of which were veighed by myselt

Fly-Fishing

The brown rout rises well th the $a_{\mathrm{v}}$, well if not ter in At er than in England, and does tht so fastidious to the color ur s? fly offered my of th pupu lies will answer, nd it me to 1 in- 


\section{$T !=$ Trout}

herited fancy for : e imit ions of the $\lambda_{i}$ ayfly, the gree" and gray a akes, when the natural May fly is on the water. This fly is also known as the sand-fly.

High up in the Southern Sierras, about 10,000 feet, in the neighborhood of Mount

G. Ter, Trout of the er

Whitney, California, are several $\mathrm{sF}_{\mathrm{F}}$ 's or sub-species, of "golden t ut," apnz: th related to the : ninbow trout. I $r$ heautit

and varied coloration they exc it fist of fresh vaters id rival those o.

reefs of et cs.

For many years the gol

II unt I hitney has bean les ed at vari-

was tir 3 by enthusaas? of in the 'ortsmen's journalc hu it until lately ve these fishes ! pri IV systema$\therefore$ ed. In the sun 'm 1. a party headed tre Dr. Bartin! I wer nn, under the auspi es of the Un I Bureau of Fisherie proceeded wlity mentioned. an l thoroughl $d$ the differ"nt strearns, an collc.un nundreds of specimens of the trout inhabiting them. As a result of this expedition the following I 3 
Favorite Fish and Fishing

Varieties of Golden Trout

species of golden trout have been established by Dr. Evermann:

Golden Trout of Soda Creek (Salmo whitei),

Golden Trout of South Fork of Kern River (Salmo agua-bonita),

Golden Trout of Volcano Creek (Salmo rooseveld $i$ ).

These trout are all small, averaging six to eight inches, but are quite gamy and very free biters. The golden trout of Volcano Creck is the handsomest and gamest. Of this fish Dr. Evermann says:

"This is the most beautiful of all the trouts; the brilliancy and richness of the coloration is not equaled in any other known species. . . In form it is no less beautiful; its lines are perfect, the fins large and well proportioned, and the caudal peduncle strong; all fitiing it admirably for life in the turbulent waters in which it dwells. It is a small fish, however. The largest example collected by us was eleven and one-fourth inches in total length, and the heaviest one weighed ten ounces. 


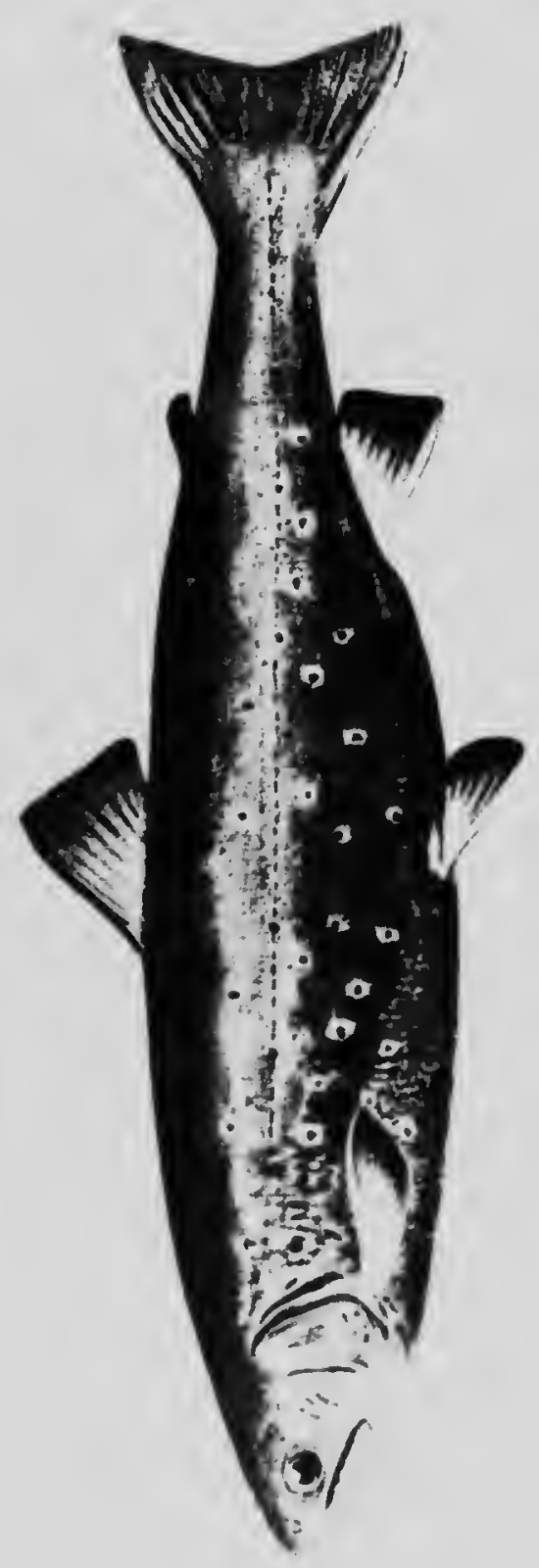

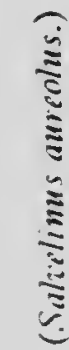

ह

ב⿳亠口冋. 


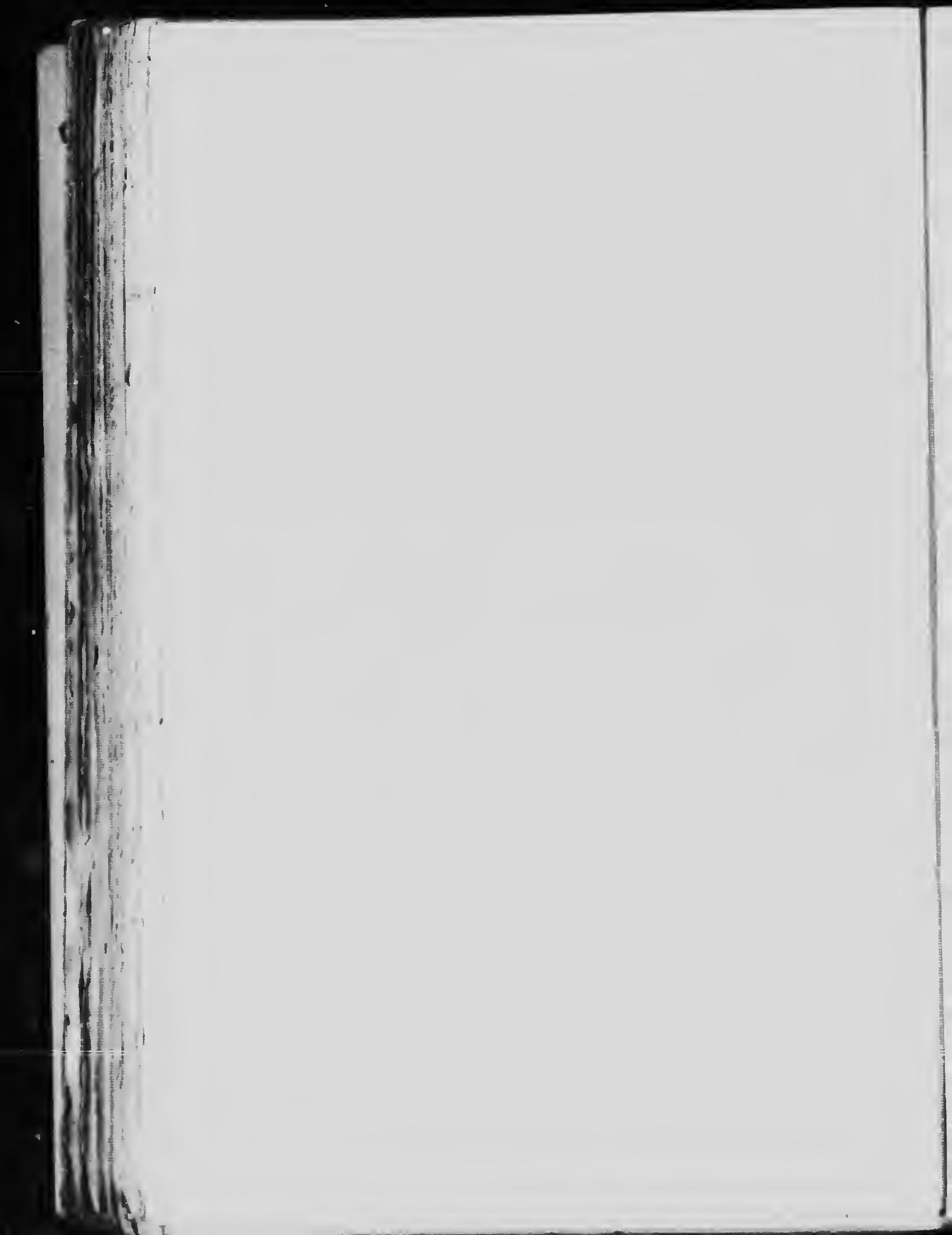




\section{The Trout}

"As a game-fish the golden trout is one of the best. It will rise to any kind of lure, including the artificial fly, and at any time of day. A No. io $\mathrm{Aly}$ is large enough, perhaps too large; No. I 2 or even smaller is much better. In the morning and again in the evening it would take the fly with a rush and make a good fight, jumping frequently when permitted to do so: during the middle of the day it rose more deliberately and could sometimes only be tempted with grasshoppers. It is a fish that does not give up soon but continues the fight. Its unusual breadth of fins and strength of caudal peciuncic, together with the turbulent water in which it dwells, enable it to make a fight equaling that offered by many larger trout."

In the autumn of 1906 several hundred golden trout from Volcano Creek were Propazation of Golden Trout brought by a fish-car to the Bozeman Fisheries Station. In the following spring sereral hundred eggs were taken from a few of the largest fish, about six inches long, and it is hoped that this beautiful trout 
Sunapee Golden Trout (Salvelinus aureolus)

\section{Favorite Fish and Fishing}

may be successfully propagated, if only for its handsome coloration.

This fine fish was first described by Dr. Tarleton H. Bean, in 1887 , from Sunapee Lake, New Hampshire. It exists, also, only in one or two ponds or small lakes in the vicinity. It is almost identical with the European char (Salvclinus alpinus). It is generally supposed to be native to the waters mentioned, but there is a possibility that it was introduced from Europe. However that may be it is now recognized as a different species and a fine example of American trout. It grows to about twelve pounds in weight, but unfortunately does not rise to the fly. I have had no experience with this fish, but Dr. J. D. Quackenbos, who, more than any one else brought the fish to notice, says :

Not a Fly Fish

"As far as known it does not rise to the Ay. . Through the sunimer months it is angled for with a live minnow or smelt, in sixty or seventy feet of water, over cold bottom, in localities that have been baited. While the smelt are inshore, trolling with 


\section{The Trout}

a light fly-rod and fine tackle, either with a Trolling with Skinner spoon, No. I, or a small smelt on a Smelt single hook, will sometimes yield superb sport." 
$\downarrow$

$-$

I I

1) is

(1)

(1)

Ni!

if

I.

11

i:

(1)

1)

(1) :

(1)

(1)

(1)

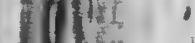

,

(1)

$\int_{1}^{1}$

10

$+$ 
HIS MAJESTY: THE SILVER KING 


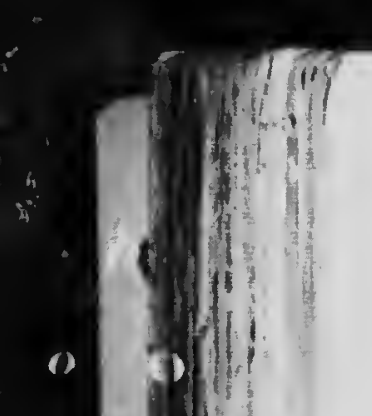




\section{HIS MAJESTY : THE SILVER KING}

TN Florida the tarpon may be found 1 during the winter east of Cape Sable in In Florida Barnes and Cards Sounds, and in Biscayne Bay. As the water becomes warmer, in February and March, it ascends the coasts. On the Gulf side it appears first at Marco, back of Cape Romano, then in the vicinity of Naples and Charlotte Harbor. Punta Rassa was formerly, and is yet, a favorite resort for Northern anglers, but Fort Myers, twenty-five miles above, on the Caloosahatchie, is now the principal rendezvous for tarpon fishing from March to May. Later the silver king wanders farther north, and during summer good fishing is abundant at any of the inlets. It is also abundant on the Texas coast. On the east coast of Florida, Jupiter and Indian River inlets are the best grounds for tarpon. The largest I have ever seen were at Indian River inlet. 


\section{Favorite Fish and Fishing}

The tarpon is a fish of the tropical seas and is peculiarly sensitive to cold. I happened to be in Florida during the winters of I 886 and I 895 when most of the orange groves were killed by freezing. At Tampa the temperature fell to $19^{\circ} \mathrm{F}$. As a result of the sudden chilling of the water I saw windrows of dead fish along the shores of the bays, especially at Charlotte Harbor. They were mostly sub-tropical fishes, and among them were hundreds of tarpon, large and small, many upward of a hundred pounds.

Bait Fishing

While the tarpon will take any kind of fish bait, or artificial bait for that matter, especially at the inlets or up the streams, mullet bait is generally used; and the prevalent method of allowing the fish to swallow the bait so as to hook him in the gullet will probably always be practiced, for it is the only sure plan to bring him to gaff. If hooked in the mouth or tongue when trolling or casting, he almost invariably shakes out the hook and escapes. Once in a while, however, one will be landed in this manner, 


\section{The Silver King}

$:$ id even with the artificial Hy, in which event the honest angler feels a just pride in his happy performance and is the envy of them all.

I have had the best sport with tarpon, as early as 1878 , up the fresh water rivers, Fly Fishing for Tarpon using a salmon fly-rod and large gaudy flies. These were the small fry, however, rumning from ten to lorty pounds, but even at these weights they demanded the best skill of the angler, inasmuch as they were hooked in the mouth, and only occasionally could one be landed.

At that time my old friend, Dr. Ken- Fishing at worty, of Jacksonville, Florida, was wild Mayport over tarpon fishing at Mayport, at the mouth of St. John's River. But the Doctor and his friends were using handlines, believing it impossible to kill one on the rod, and moreover, thought it quite a feat to land one with the handline, hooked in the mouth, as indeed it was. I remember well a wonderful array of big hooks attached to a metal strip that the good Doctor showed me as his latest invention to hold fast to a silver king. 


\section{Favorite Fish and Fishing}

I think it was owing to Dr. Kenworty's enthusiasm in the matter that induced Colonel W. H. Wood, of New York, an old striped bass angler, to go to Florida to try conclusions with the tarpon with striped bass rod and tackle. At any rate, to Colonel Wood belongs the credit of bringing rod fishing for tarpon into the prominence and popularity it now holds.

The First Tarpon on a Rod
In the winter of I 880-I Mr. Samuel H. Jones, of Philadelphia, while trolling with the spoon in the Fort Pierce channel of Indian River Inlet, hooked and landed, after a contest of two hours, a tarpon weighing one hundred and seventy pounds with striped bass rod and tackle. This was the first tarpon of more than one hundred pounds killed on the rod. I was at that locality the following winter, and learned the full particulars of the extraordinary performance from Mr. Thomas Paine (son of Judge Paine, of Fort Capron), who was Mr. Jones's boatman on the occasion. Afterward I received a full account of it from a son of Mr. Jones, who was with him and

\section{24}




\section{The Silver King}

witnessed the capture of the immense fish. It is worthy of note that the fish was hooked in the mouth and not in the gullet. Honor to whom honor is due.

In 1885 Colonel W. H. Wood, of New Record Tarpon York, made rod fishing for tarpon famous at Puntarassa. In March, I886, I was present when he brought in from Estero Bay his record fish of one hundred and forty-six pounds, and two others weighing nearly a hundred each. They were hung up and photographed by my shipmate, Judge Nicholas Longworth, of Cincinnati.

My friend, Mrs. T. J. Bachmann, of Florida, formerly Mrs. Stagg, of Kentucky, The Largest to Date was high hook for many years with her two hundred-and-five-pound fish, which was mounted and exhibited in my department at the Chicago World's Fair, together with one of one hundred and ninety-six pounds caught by Mr. McGregor, of New York. Mr. Edward vom Hofe, of New York, in 1898, caught one at Captiva Pass weighing two hundred and eleven pounds, and Mr. N. M. George, of Danbury, Connecticut, 


\section{Favorite Fish and Fishing}

Tarpon Tackle

Tarpon Bait Fishing

afterward took one at Biscayne Bay of two hundred and thirteen pounds.

The equipment for tarpon fishing consists of a hea $y$ striped bass rod, seven or eight feet long, a first-class multiplying reel, I 00 to I 50 yards of Cuttyhunk line of from I $\delta$ to 2 I threads, and knobbed hooks, Nos. 8-o to ro-o. The tarpon has no sharp teeth, but the edges of its jaws are sharp enough to cut an ordinary line, and open vertically. Owing to this fact it is imperative that a snell of wire, whit-leather, or of heavy braided cotton line be used.

Tarpon fishing, as usually practiced, requires a level head, considerable muscle, and a just appreciation of the tensile strength of tackle. With no thought of disparagement, it is none the less true, that not much real angling knowledge-as that term is understood in relation to salmon, trout or black bass fishing-is required. The hook is baited with mullet or other fish bait, a long cast made, and the bait allowed to remain on the bottom until "negotiated" by the luge fish. Usually a I 26 


\section{The Silver King}

lot of slack line is pulled from the reel and coiled in the boat, in order that the fish may carry off the bait without hindrance, and so be induced to swallow it, when he is hooked in the gullet. Then the trouble begins. Ficeling the prick of the hook he vaults into the air several feet, and continues to do so until exhausted, when he is recled in to the gaff or taken ashore into shallow water, the latter plan being the best.

Fi:ıge fishes like the tarpon, jewfish or tuna are sooner brought to gaff by " pumpPumping Them In ing," as it is called. It is effected in this way: The rod is raiscd upward and backward and then quickly jowered to a horizontal position, when advantage is taken of any decreased tension or slack line by recling it in as rapidly as possible. This operation is repeated whencer practicable, and as often as possible.

The plan of having a quantity of slack Tarpon Reel line in the boat, as mentioned, is really not necessary with a recl of the best quality, and is open to sereral obvious oljections. A 


\section{Favorite Fish and Fishing}

A Tarpon Enthusiast

tarpon would not notice the slight pull on the line from such a reel, as it renders or the slightest provocation. A leather brake sewed to one of the bars of the reel, or on of the patented drag-handles, is absolutely necessary in playing a tarpon, otherwise th fingers are likely to suffer in consequence 0 the fierce rushes of the fish for freedom.

My good friend Major-General Eustac Hill, a retired officer of the British army whom I initiated in tarpon fishing, declare to me-after an experience of thirty-fiv years in India, and ten summers in Norway salmon fishing-that the two finest sports it the world were pig-sticking and tarpon fish ing, notwithstanding he has a record o two hundred salmon in a single scasonand there you are. But the General is on of the "strenuous" type of sportsmen. B the way his grandfather. Admiral Keppe the ranking officer of the British navy, die a few years ago at the advanced age o ninety-four years; by a special Act of Pa 'iament he was continued in active servic until the day of his death. 


\section{$\mathrm{g}$}

pull on ders on er brake , or one ssolutely wise the uence of dom.

Eustace h army, declared hirty-five Norway, sports in pon fishecord of seasonal is one nen. By Keppel, avy, died 1 age of $t$ of Par. e service

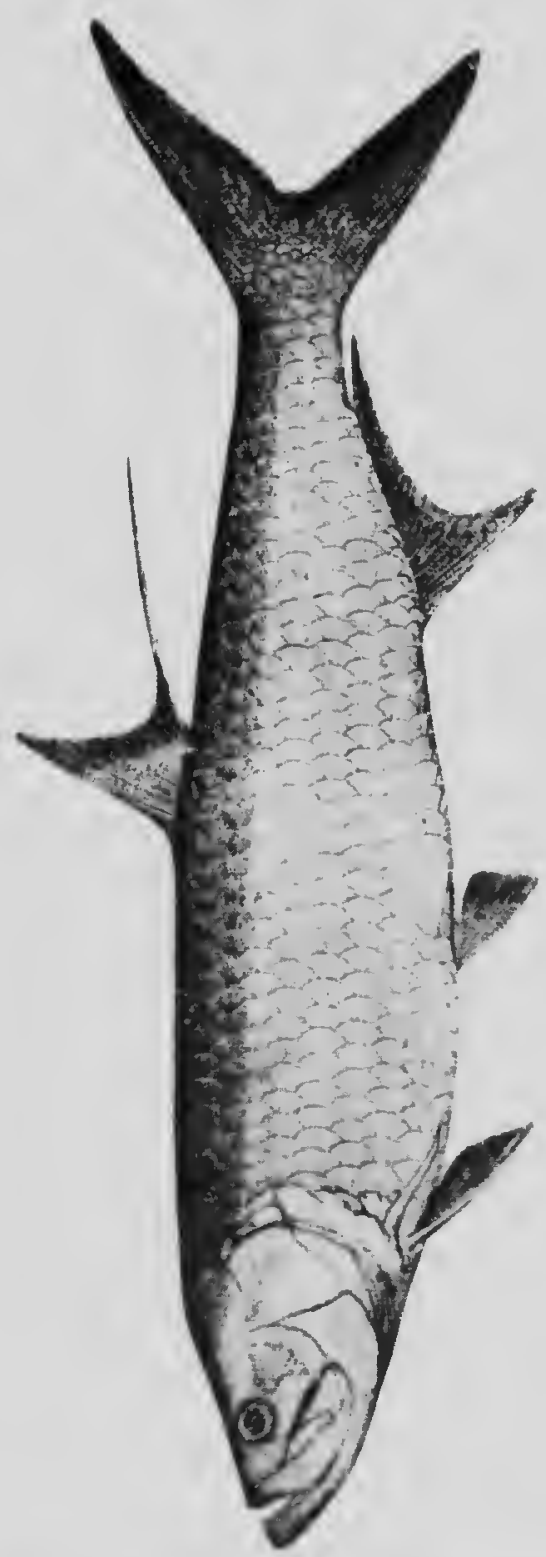

3
$\vdots$
$\vdots$
$\vdots$
$\vdots$
$\vdots$
$\vdots$
$\vdots$
$\vdots$
$\vdots$ 


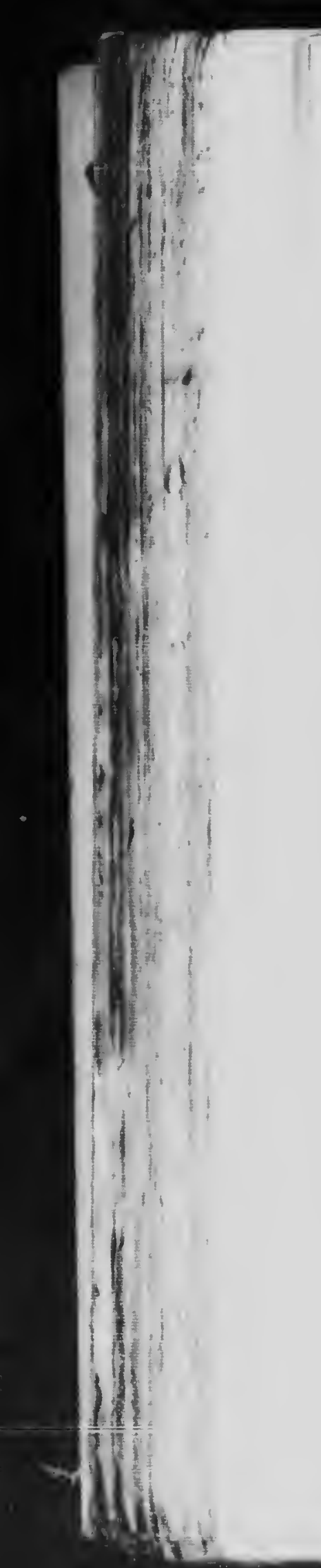




\section{The Silver King}

During the winter months the tarpon may be found in the shallow water of bays Some of His of southern Florida, basking in the sun, under the mangroves. In such situations many are speared, or "grained," as it is called by native fishermen. But during the summer they may be seen by hundreds rolling and playing on the surface, at ary of the deep inlets of either coast. At this time the angler, by trolling or surface fishing, may get scores of strikes in an hour, but as to landing them-that is another fish story.

The tarpon breeds in the West Indies and Central America, but not, I believe, in Breeding
Grounds Florida. At all events, as a collector of fishes I have combed the shores and rivers of Florida, with a fine-meshed seine, from Titusville on the east coast to Tampa on the west coast, but never found a tarpon of less size than a foot in length. If they breed in the bay's or rivers I certainly would have found some smaller ones.

Late in the winter of I892, when en- A russle with a gaged in the preparation of the Lnited 


\section{Favorite Fish and Fishing}

States Fish Commission exhibit for the Chicago World's Fair, my duties took me to Florida to collect fishes for the purpose of making gelatin casts of them for the great exposition. I was very desirous of obtaining a tarpon, but the season being backward and the water cold, none had been taken on the west coast up to that time-about

Chance for a Tarnon

Sarasota Bay the middle of March.

Tarpon
putting in a pound net in Sarasota Bay as
an experiment, it being the first ever intro-
duced on the west coast of Florida. Here,
then, seemed to be my only chance of get-
ting a tarpon, as the time allotted for my
stay in Florida was rapidly drawing to a
close. Mr. Savarese promised to give me
carte blanche instructions to the man in
charge when the net was ready.
Accordingly, in a few days I left
Tampa on the steamer for Braidentown,
on the Manatce River, at the beginning
of a norther. At Braidentown I engaged a
carriage and drove across country, through

One day John Savarese, a prominent fish dealer of Tampa, informed me that he was putting in a pound net in Sarasota Bay as an experiment, it being the first ever introthen, seemed to be my only chance of getting a tarpon, as the time allotted for my stay in Florida was rapidly drawing to a close. Mr. Savarese promised to give me carte blanche instructions to the man in charge when the net was ready. 


\section{The Silver King}

the pine woods, to Sarasota Bay, arriving at The Palms, the charming little hotel built by good Mother Jones, who is now in Heaven. I enjoyed one of her matchless suppers after my drive through the rain and in the face of the fierce norther.

I found that the shanty of Captain Faulk- Interviewing ner, who had charge of the pound net, was the Captain adjoining the hotel grounds. I interviewed him that evening, when he promised to go out to the net the next afternoon if the wind abated. As I knew that the northers of Florida lasted several days, and my time was limited, I replied that I would visit the net the next day.

On the next afternoon the norther was in full force and the sea running high. It required a good deal of persuasion for Faulkner to consent, but fortunately he yielded at last to my entrezries. We embarked in a sixteen-foot rowboat-Faulkner, a white man, a negro, and myself. The net was two miles down the bay. The wind was behind us. so we were soon there, drenched with spray, and quite cold. 
Favorite Fish and Fishing

The Expected Happens

The Coveted Prize
The painter of the boat was made fast to one of the net stakes, and the men got into a large bateau that was moored alongside the trap of the net. After closing the tunnel of the net and loosening the stays they began hauling up the trap. Then the expected happened. A tarpon leaped high in the air in his attempt to escape, but striking one of the stakes, he fell back again into the trap.

"Captain!" I cried, " don't let him get away; that's the fellow I'm aiter!"

The net was swarming with fish of all kinds and sizes, from a ten-inch mullet to a ten-foot shark. Finally Captain Faulkner got his gatf-hook into the tarpon's gills. "What shall I do with hin?" he asked.

"Put him in my boat," I answered.

Which was easier said than done, for it took the three of them to transfer him to iny craft, from which I remored the midlle thwarts to male rov!n for his silver kingship. He wis deposited on the bottom of the boat and the men resumed work.

Then the silver king rose up in his 132 


\section{The Silver King}

majesty and stood on his tail, towering above me, for he was over six feet tall. I He Rose in $\mathrm{His}$ Might immediately grabbed him in nyy arms with a grip born of desperation, for I knew it was my last and only chance to secure a tarpon. The boat was dancing about on the crest of the sea and the north wind howled. The palmettos on shore lashed their broad fronds as they bent before the gale. It was a difficult matter at best to keep one's feet, but with a slippery silver giant in one's arms it was a wonder that we both did not go overboard.

But I held on to him and got him down in the bottom of the boat. No sooner A Slippery Customer down, however, than he was up angain. This time he slipped from my grasp and went down full length on the botton with a noise like the felling of an $0: x$ in an abattoir, causing the men to pause in their work and look around.

"Let him go!" shouted the Captain. "He'll knock the buttom of the boat out and drown you!"

"I'll risk it," I replied. "I won't let 133 


\section{Favorite Fish and Fishing}

A Wild Dance

A Whipparee him go if I have to go overboard with him. I am bound to land him in Washington if I have to go by water."

I tried sitting on him then, but he would not be sat down upon, and up he came again. Again we had it, dancing about in the slippery boat on a raging sea. It was a medley of waltz, two-step, polka, and galop. with a slimy silver king for a partner. He seemed to weigh a ton and to be ten feet tall. At last I got him down again and replaced one of the thwarts above him. I got out my knife, lifted up his immense gill cover and severed his heart.

The men were scooping out their fare of mullet, red-fish, and sea-trout. The large shark, a number of smaller ones, plenty of rays, and hundreds of other fish were still in the trap. Seeing a fine whip ray some four fect across and as spotted as a leopard, I shouted, 'Captain, I want that whipparee!"

They soon gaffed him and deposited him on top of my tarpon. Then observing a huge sting ray, larger than the whip ray, I 


\section{The Silver King}

again called out: "Cap, gaff that big sting- The Stingaree aree!"

"Not much," he answered.

"Yes," I continued, "I really want him; put him in my boat."

"You don't mean it. Why, he'll kill you."

" I'll risk it," I said; " haul him over in my boat."

"I'm afraid of him. His sting is six inches long!"

I prevailed on him finally, and after much careful management they hove it into my boat. "Look out for his sting!" cried Faulkner. "It's sure death!"

"Fore God! Marse Doctor," said the negro, "I wouldn't stay in de boat wid dat A Scared debbil stingaree for a hundred acres in de promise' land!"

But I covered the sting, the dreaded weapon, with a piece of sailcloth and planted a foot on each side of it. The men then put their fare of marketable fish on the top of my specimens, which kept them in place, and then emptied the trap of the 


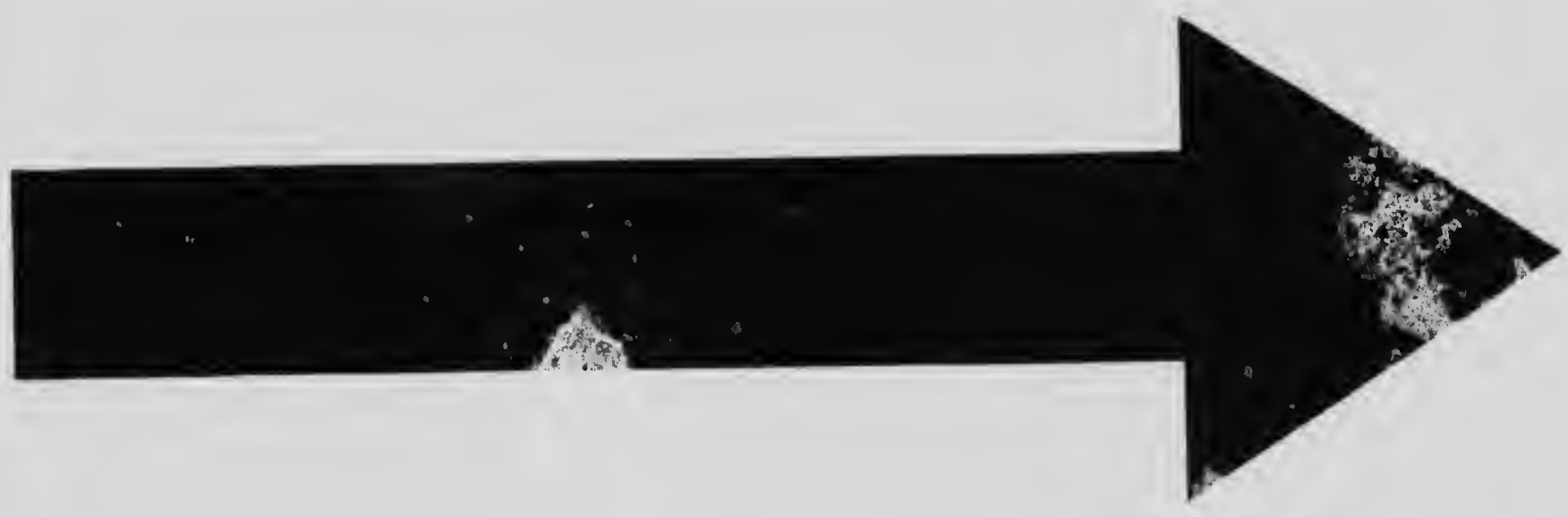



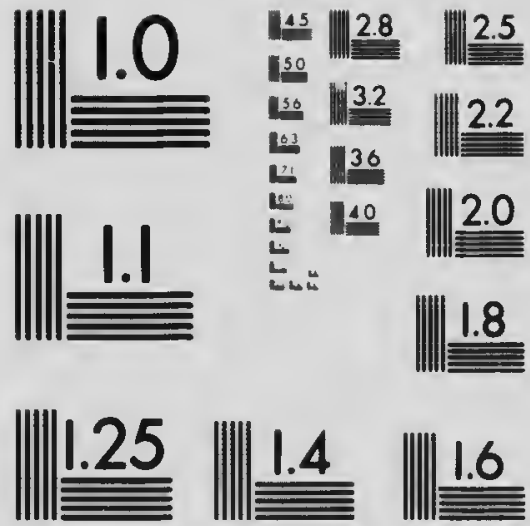

MICROCOPY RESOLUTION TEST CHART

NATIONAL BUREAU OF STANDARDS STANDARD REFERENCE MATERIAL 1010a (ANSI and ISO TEST CHART NO 2) 
Favorite Fish and Fishing

A Blue Norther rest of the fish. Strange to say, the large shark, at least ten feet long, was completely smothered under the mass of fish and had to be gaffed and hauled overboard by main strength. It was now dark, with two miles to row in the teeth of a blue norther. We arrived at the hotel pier nearly frozen.

"Captain Faulkner," said I, " it's ten do!lars in your inside pocket if you get my fish up to Hunter's Point by morning to meet the Tampa fish steaner."

The wind lulled somewhat at midnight, when they started in the sailboat; but it took them until daylight to beat up the fifteen miles to Hunter's Point, where my specimens were put on ice with the market fish and taker on the steamer Mistletoe to Tampa.

Sorry Plight of the Captain
The next day but one I went to Faulk. ner's shanty, by previous appointnient, for another trip to the pound net. I found the Captain sitting by his stove in a sorry plight. His head and face were swathed in bandages and badly swollen.

"Why, Captain!" I exclaimed, "what's 136 


\section{The Silver King}

the matter? I want to go out to the net this afternoon."

"Matter enough," he replied ruefully. Tic Douloureux "I've been nearly dead with neuralgia from going out to the net day before yesterday. Look at my face! I wouldn't go to-day for all the fish in Sarasota Bay. You must be made of whit-leather or whalebone!"

Next morning the storm subsided and I returned to Tampa. At the fish house of Mr. Savarese, I found my specimens in fine condition in an immense icebox. We at once began to pack them for shipment to Washington. As the tarpon lay on the floor Mr. Savarese asked, "What will he weigh?"

"IVell," I replied. " you may guess his A Sure Thing weight, but I have had a Graeco-Roman wrestling match with him and I know his weight to a pound."

Mr. Savarese then measured him with a tape line.

"Six feet and three inches," he announced, "and he will weigh one hundred and fifty pounds." 
A Fair Specimen

Favorite Fish and Fishiing

"No," I rejoined, " not so much. $\mathrm{He}$ might weigh your figure in a few months with plenty of food and warmer water, but his present weight is one hundred and twenty-five pounds."

We put hirn on the scale, which he tipped at one hundred and twenty-four pounds.

The hundreds of thousands of visitors to the World's Fair who admired the graceful proportions of this tarpon, in the gelatin cast, painted in life colors, and hung in the Government building, little imagined the hardships and excitement attending its capture, or the subsequent swelled face of poor Captain Faulkner. 




\section{FIORIDA FISH AND FISHING}

T the yuletide, or during the Christras $A$ he $y$.etize $A$ holidays, the lakes and streams of the North and West are locked fest in the icy chains of winter. The waters arr then a sealed book to the angler, who, unless he indulges in the questionable sport of fishing through the ice, is consoled only by retrospective pleasures when orerhauling his rods and flybooks. Not so, however, in the sunny waters of Florida, where fishing is, on the whole, at its best at the time of the Christmas festivities, if such a season can be realized by the Northern angler amid the profusion of fruits, flowers, and foliage.

To one accustomed to the nierry jingle of sleigh bells and to coursing swiftly, steel shod, over the trozen pools he loves so Transition we'l, it is really a marvelous, but pleasing, tr? nsition to be able to cast his bait or flies during the season of the yuletide.

\section{4 I}




\section{Favorite Fish and Fishing}

Climate of Floride

Better than the Mediterranean
Florida has one of the finest and must genial continental winter climates in the world. One can live in the open air the winter through, without discomfort, as it seldom rains during that season, and therein lies the great and lasting benefit to the invalid who requires an open-air life and nature's great restorers, fresh air, warm sunshine, moderate exercise and sound, refreshing sleep. He will be told that Florida has a damp climate by his physician who has never been in the state, and will be advised to go to a dry climate. But the dampness of Florida is not an exhalation from the soil, which is dry sand, but is the humid, salt air from the sea, which with the balsamic fragrance of the pines, conduces to the health and well-being of the invalid, and to the pleasure and enjoyment of the angler and sportsman.

I have suffered more from raw, chilly weather in the much-lauded winter climates of southern France, Italy, and even Morocco, than in southern Florida. And while the shooting along the Mediterranean I 42 


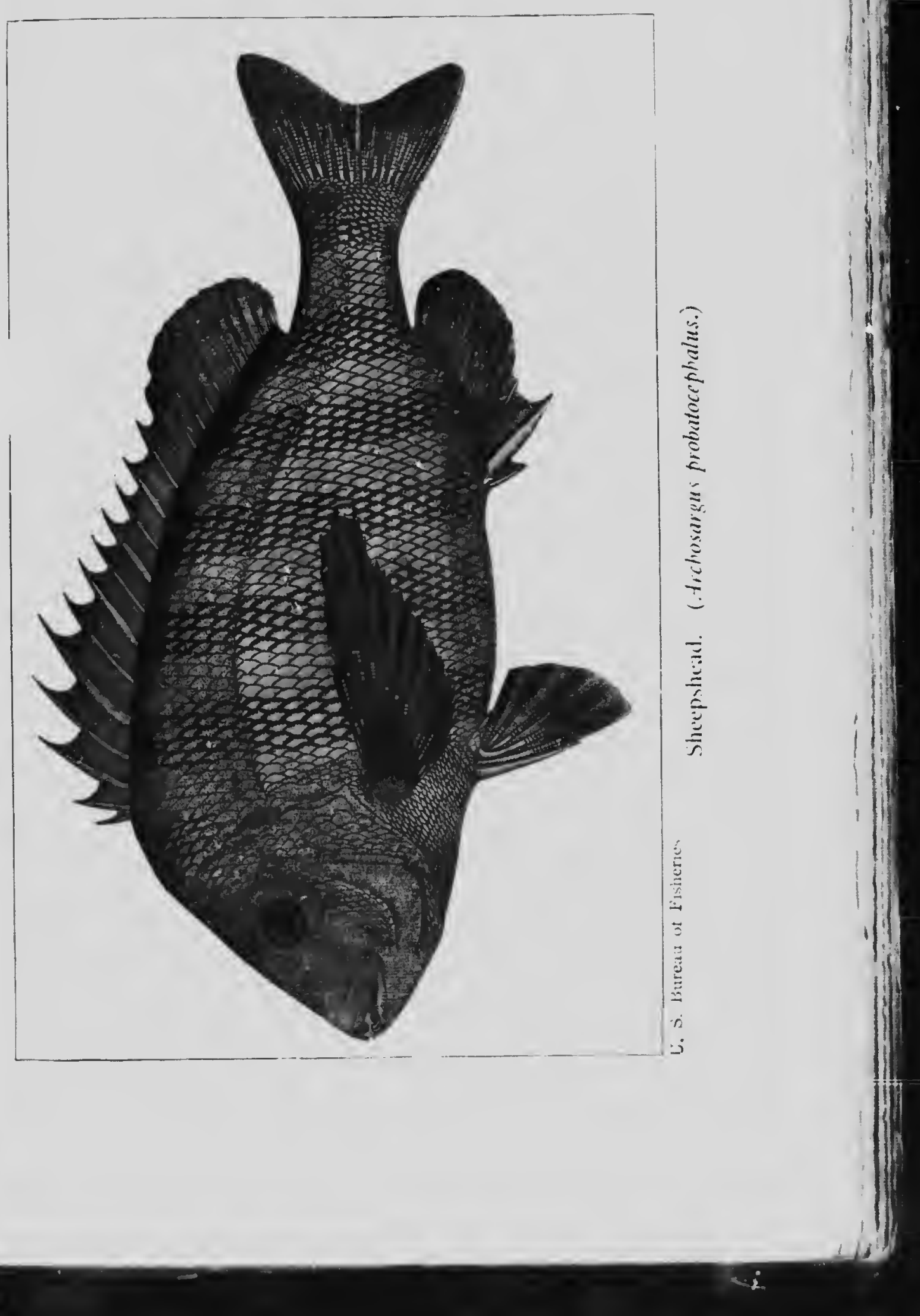




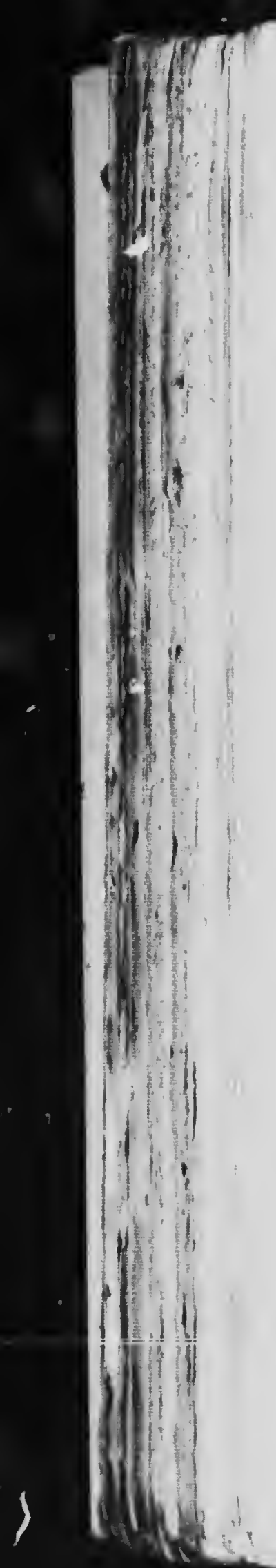




\section{Florida Fish and Fishing}

in winter is very fair for the red-legged Good Shooting partridge, migratory quail and snipe, it is not to be compared with the shooting to be had in Florida, either for abundance or variety of game. In fact, Florida is hardly excelled hy any state in the Union in its possibilities of fishing and shooting. And then these sports can be practiced at a time whin the streams and lakes of the North are bound in icy fetters, and the woods and fields buried beneath the hibernal mantle of snow.

The angler can hardly go amiss in any Florida Fishing section of Florida for his favorite sport. Wherever there is reasonably pure or uncontaminated water he will find some species of $t \in$ finny tribe. And the true angler, he who loves the sport for its own sake, can be satisfied so long as his tackle is commensurate with his quarry. With his stout tools and tackle he enjoys the phenomenal leaps of the tarpon, or the leviathan struggles of the jewfish. With his delicate split-bamboo wand, silken line, gossamer leader and fairy flies, he enjoys 


\section{Favorite Fish and Fishing}

The Sheepshead (Archosargus probatocephalus)

equally well, perhaps more, the wary bream or crappie of the fresh waters. Better still, with suitable tackle the acknowledged game fish, par excellence, of America, the black bass, will yield him sport galore.

'The lover of sheepsheading will find his quarry about the piling of old wharves or about the oyster reefs, while his bait-fiddler crabs-abound in myriads on the beaches. I once saw the catch of a man who took three hundred on a single tide from Summerlin's cattle wharf at Punrarassa. He should have been indicted, tried ar.. convicted by a jury of honest anglers and sentenced to a term of imprisonment by a judge of fair sport. The sheepshead, with its human-like incisors, is very adroit at nibbling the bait from the hook, and must be circumvented by a quick, sharp turn of the wrist upon the least provocation n intimation of its intentions; this will drive the hook into its well-paved jaw six times in ten. When hooked, the sheepshcad makes strenuous efforts to reach the bottom which is very trying to a light rod. The 


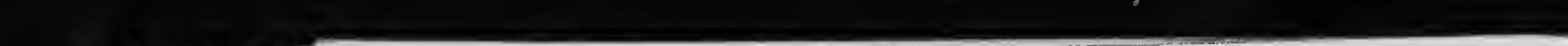




\section{Florida Fish and Fishing}

fish should be kept near the surface until the spring of the rod compels it to give up the contest. A school of sheepshead, in their striped suits, reminds one of a gang of prison convicts, begging their pardon for the comparison; of course all comparisons are odious. The same rod and tackle hereafter recommended for cavalli, etc., answers for sheepshead.

The cavalli, or jack, with its second cousins, the runner, the horse-eye jack, the leather jack, amber jack and the pompanos, The Cavalli are closely allied to the mackerels, and all are game-fishes. The cavalli can be taken with the fly, bait, or trolling-spoon, and when hooked puts up a vigorous fight. It is a handsome silvery fish, bound in blue and yellow, and can be found about the inlets and tideways. In rare instances it reaches twenty pounds in weight, but is usually taken from two to ten pounds. Ordinary black bass tackle is suitable for the cavalli, with a sinker adapted to the strength of the tide. For baits, any small fish, as anchovy and pilchard, will answer, while

145 


\section{Favorite Fish and Fishing}

shrimp and cut bait can also be used. Gaudy and attractive flies are the best for fly-fishing, which can be practiced from piers, a boat, or from the points of inlets. The most popular way of fishing is by troll-

The Sea Trout (Cynoscion nebulosus)

The Spanish IAackerel (Scomberomorus maculatus) ing in the channels, when a spoon with but a single hook should be used.

The sea-trout is a surface-feeding fish, and a game one. It is not a trout, of course, but is akin to the Northern weakfish, and is called a trout, by courtesy, because of its black spots. It takes the fly because it cannot help it, and will give the angler ample exercise with a light rod before it is landed. Being more high-minded than the sheepshead, it does its fighting on the surface. The sea-trout is not a bushwhacker nor yet a guerilla. It sometimes runs up the streams to fresh water.

The Spanish mackerel is not a whit behind the sea-trout in gameness, or in its aptitude or fancy for the feathers and tinsel of an artificial fly. It is the trimmest built fish that swims, and always reminds me of a beautiful racing yacht. It feeds and 146 


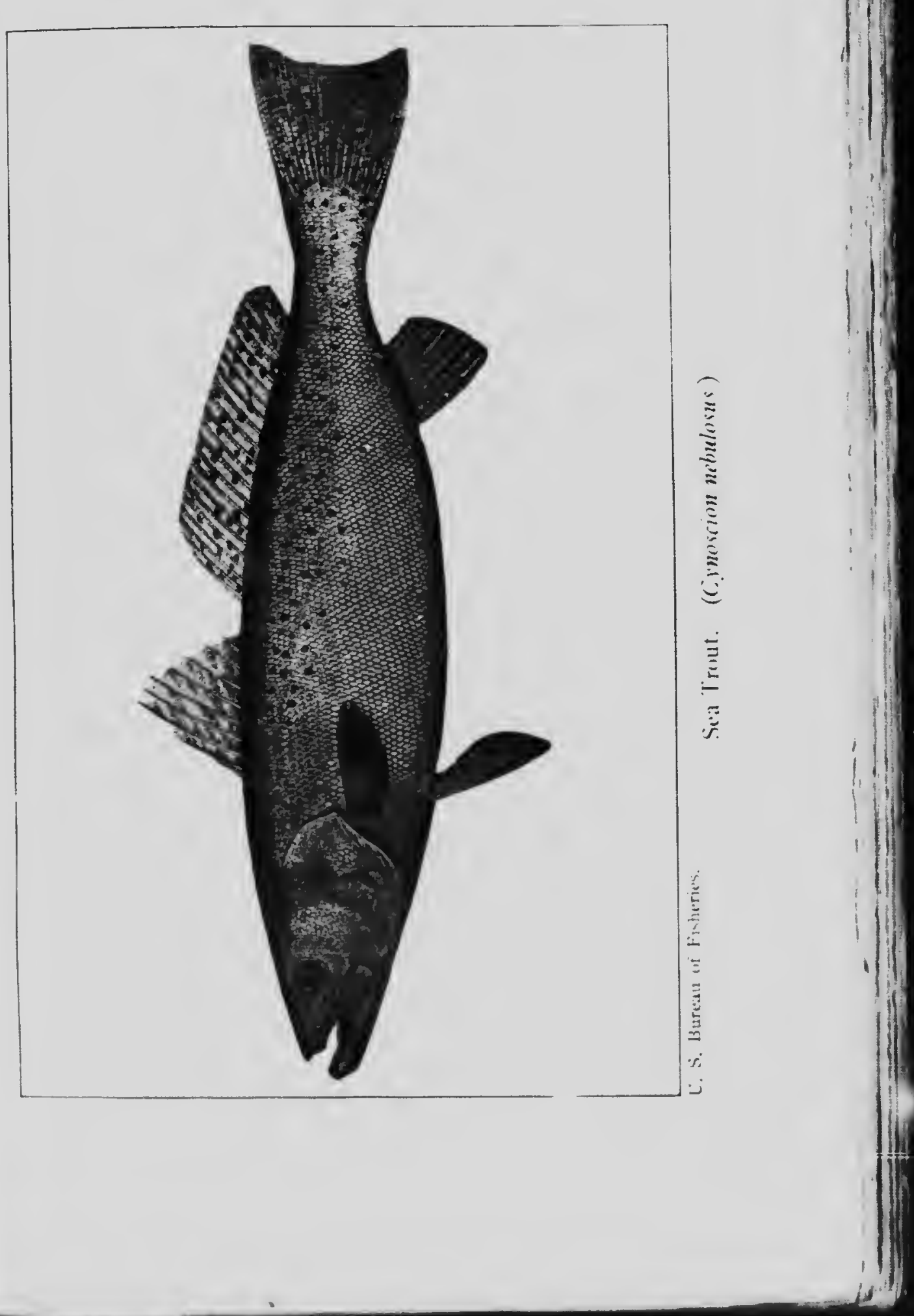




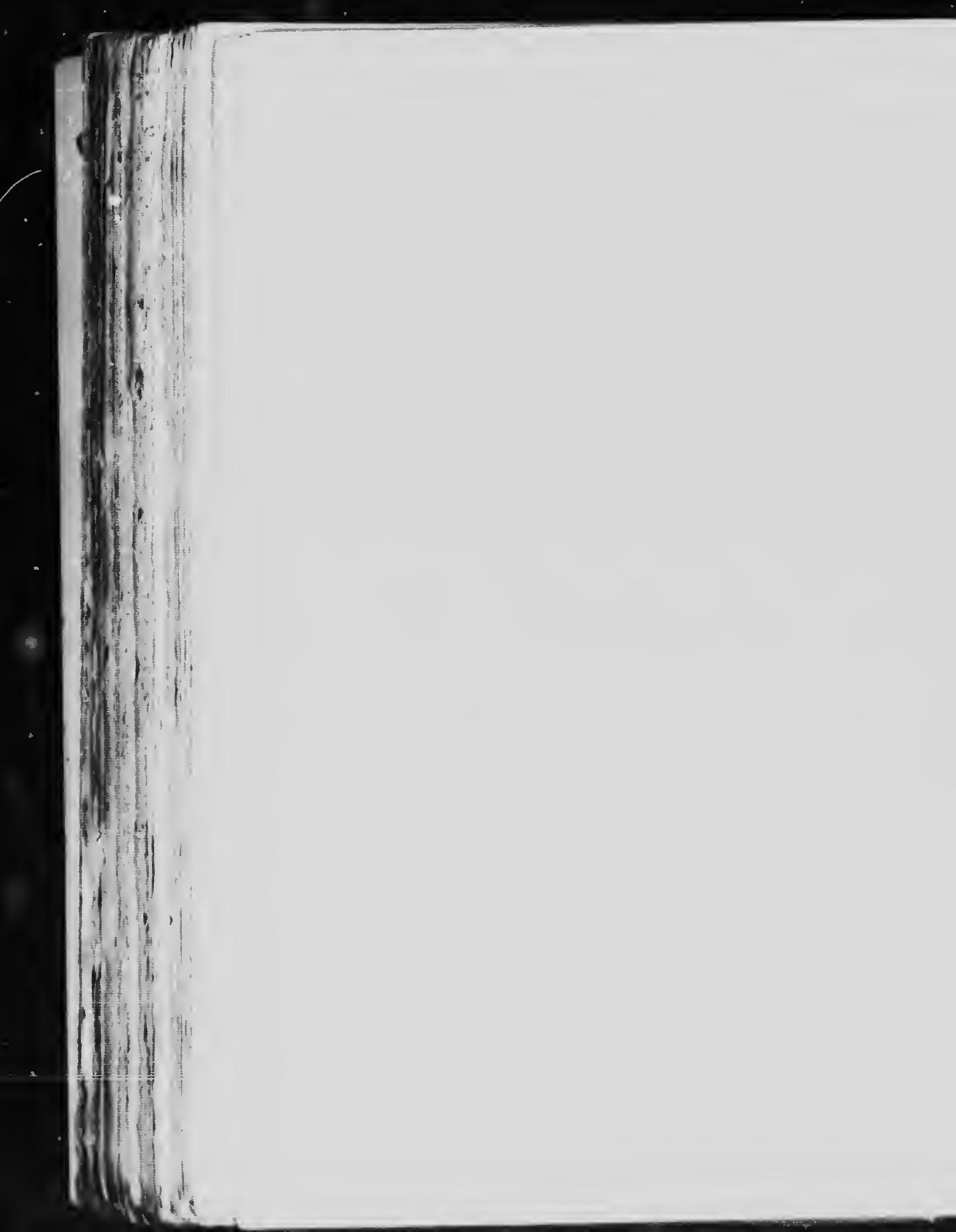




\section{Florida ${ }^{-}$sh and Fishin}

fights on the surface and in the open, displaying its silver and blue tunic with gold buttons to good advantage. They move in battalions along the outer shores during winter, but in March and April enter the inlets in companies, and then afford fine sport to the angler.

When the Spanish mackerel is running Shore Fishing into the bays and inlets, it is often accompanied by the sea-trout (spotted weakfish). Both fishes are surface feeders and take hait or the artificial fly eagerly, as stated. They run in sriools at this season, and are readily seer as they plow along the surface, creating quite a ripple.

The fishing at this time is practical from wharves or the points of inlets and passes.

Th: long piers at Port Tampa and St. Petersburg on the west coast are favorite places. The fishing is done on the flood tide, mostly, but often at the last of the ebb. No special directions are needed when th. fish are running in schools, except to kee? the bait or fly in constant motion on the surface-the fish will do the rest. 
Favorite Fish and ishing

Both are game-fishes of high degree, and the angler will have a!l he can attend to after hooking one on light tackle. As food fishes they are excellent. I prefer to fish from the sand-spits at the mouths of inlets, or if near a pier to fish from a boat moored alongside, as the fish are not so likely to see one, and they are more easily landed.

Bait Fishing

Ordinary black bass tackle is quite suitable for either fish, with fly or bait. Braided linen lines are preferable, however, to silk ones, as the latter soon rot in salt water. A gut leader about four feet long and snelled hooks, Nos. 1 to 3 , are all right for bait-fishing. The best bait is a small sardine, anchovy or mullet, though the casting spoon, with a single hook, or a pearl squid of small size may be used if kept in constant motion on the surface.

Fly-Fishing

For fly-fishing a single fly is sufficient, of any bright pattern, with some gilt or silver tinsel on the body, as the silver doctor, tied on No. 3 hooks. A long-handled landingnet is indispensable.

The kirgfish-not the fish known by that 148 

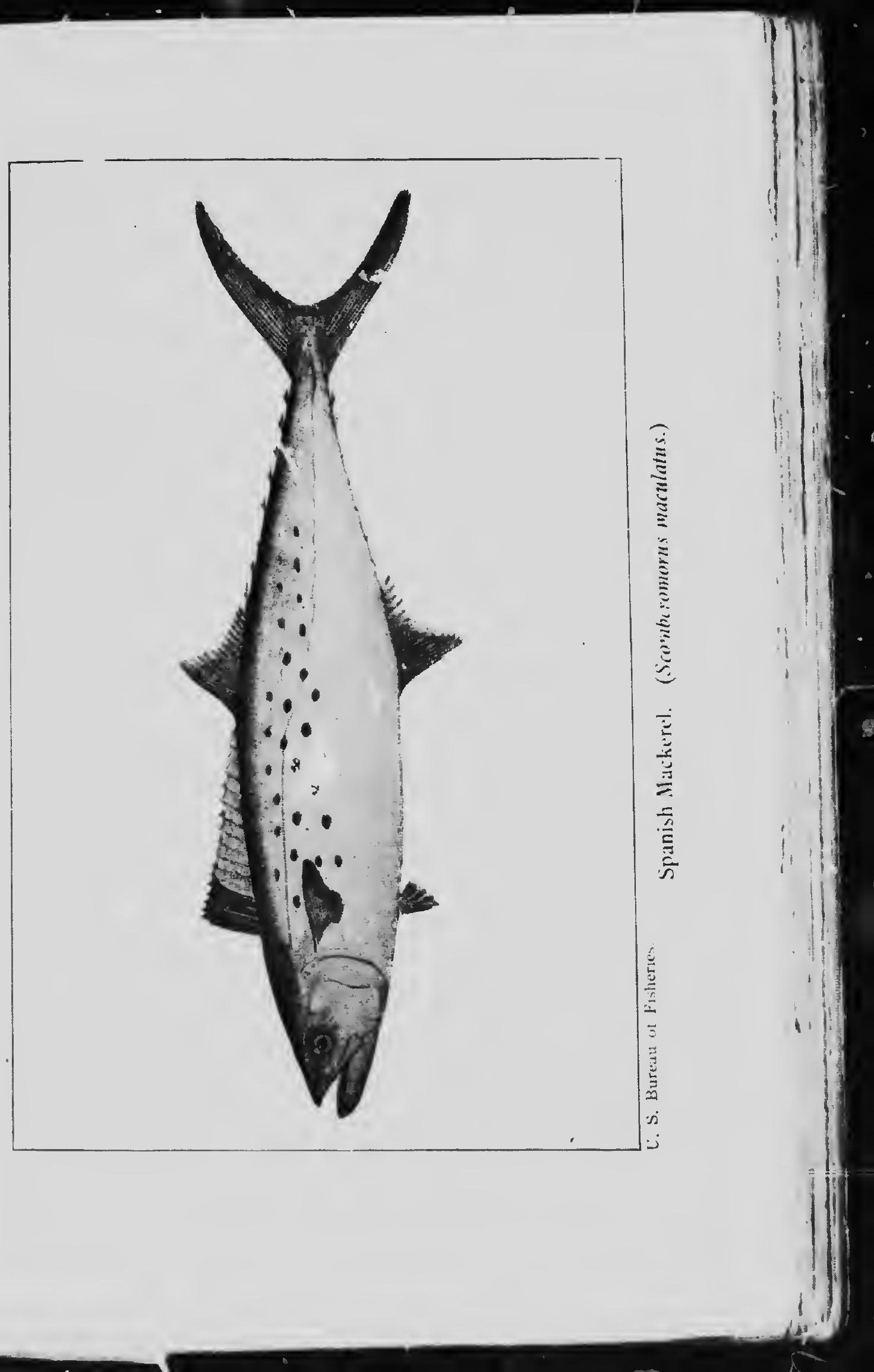


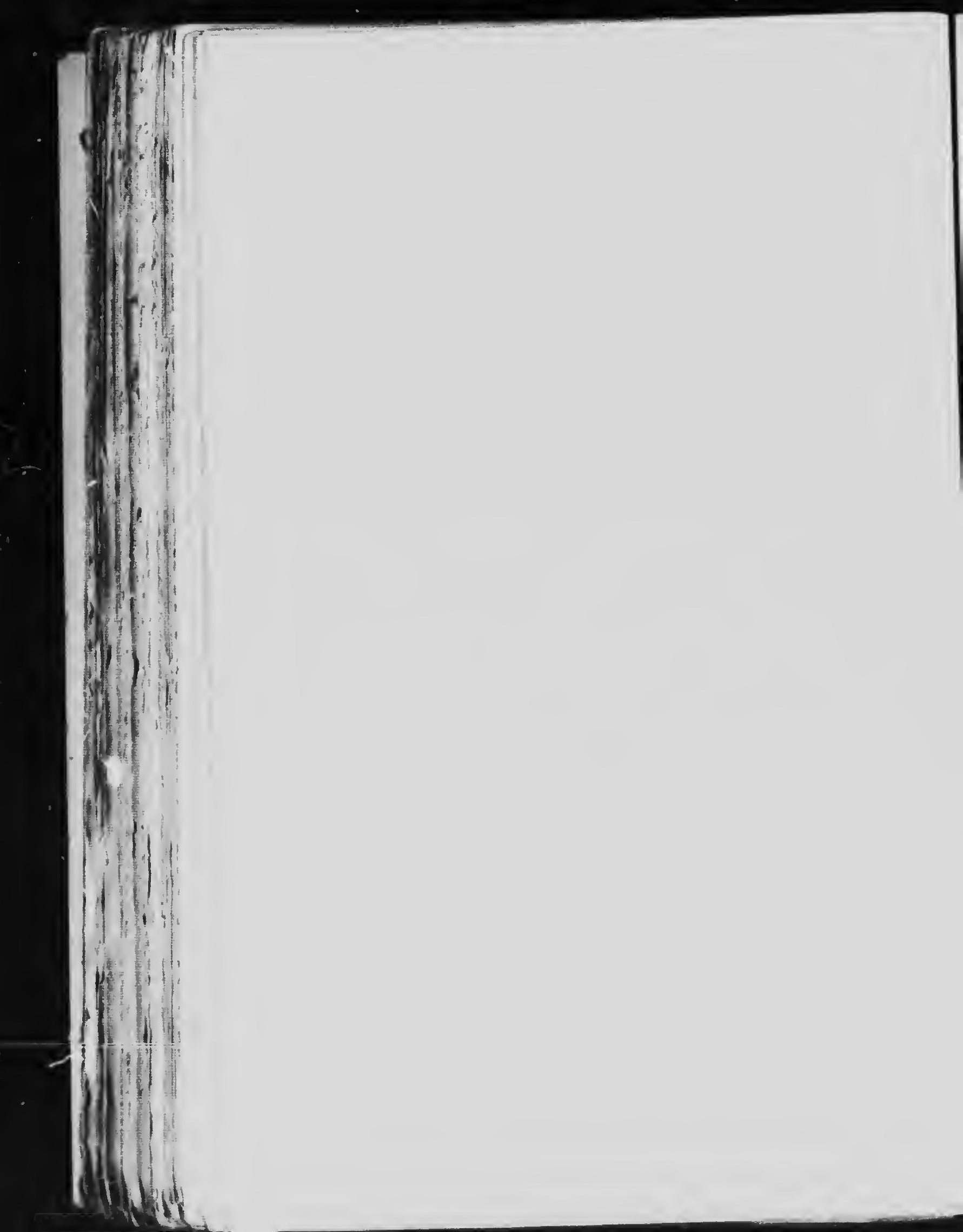




\section{Florida Fish and Fishing}

name in Northern waters, but a second cou- The Kingfish sin to the Spanish mackerel-is found along (Scomberomorus the reefs from Cape Florida to Boca Chica. It is one of the principal food fishes of Key West, and is taken by the fishermen trolling with a strip of bacon rind, which is something in the nature of an indignity, for it is a grand game-fish on the rod, and will take fly or bait on long casts. It grows much larger than the Spanish mackerel, often to twenty pounds or more, and is of a more somber hue. Its cousin, the cero, is very similar in size and appearance, but has dark spots along its gracefuil sides. All of this genus are among the best $i$ the table, as all real game-fishes are.

$T_{\text {..e }}$ best member of the drum family is the redfish, or channel bass. It is one of the common game-fishes of the brackish water bays on either coast. It is a handsome fish with a coat of old red gold and a vest of silver and pearl. It is characterized by a large black spot near the tail; sometimes there will be two spots, and occasionally these are split up into a half dozen. cavalla)

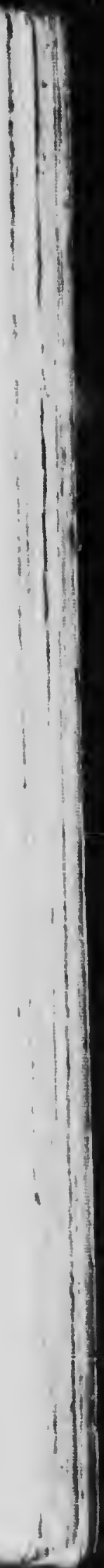




\section{Favorite Fish and Fishing}

While the redfish is very susceptible to bait it often rises to the fly, if a large and gaudy one. In either event it offers a stubborn resistance when hooked, and when of large size-from twenty to forty pounds-a good strong rod is a sine qua non, though I once killed one on a Henshall rod of eight ounces, which was fully thirty-five pounds in weight. Most of the fish-scale jewelry and artificial flowers are made from the scales of redfish.

Groupers and Snappers
All of the groupers, the red and black, the scamp and gag, are game-fishes worthy of the steel of the angler, and grow to goodly size, twenty to forty pounds. They inhabit comparatively deep water about the inlets, or along the outer shores and keys, especially in rocky situations. Being bottom feeders they must be taken with natural bait, though the trolling-spoon has its attractions. Those named are rather sober in their garb, which is more or less marbled or spotted with black, but some of the groupers about Key West are remarkably handsome fishes, and are much given to I 50 


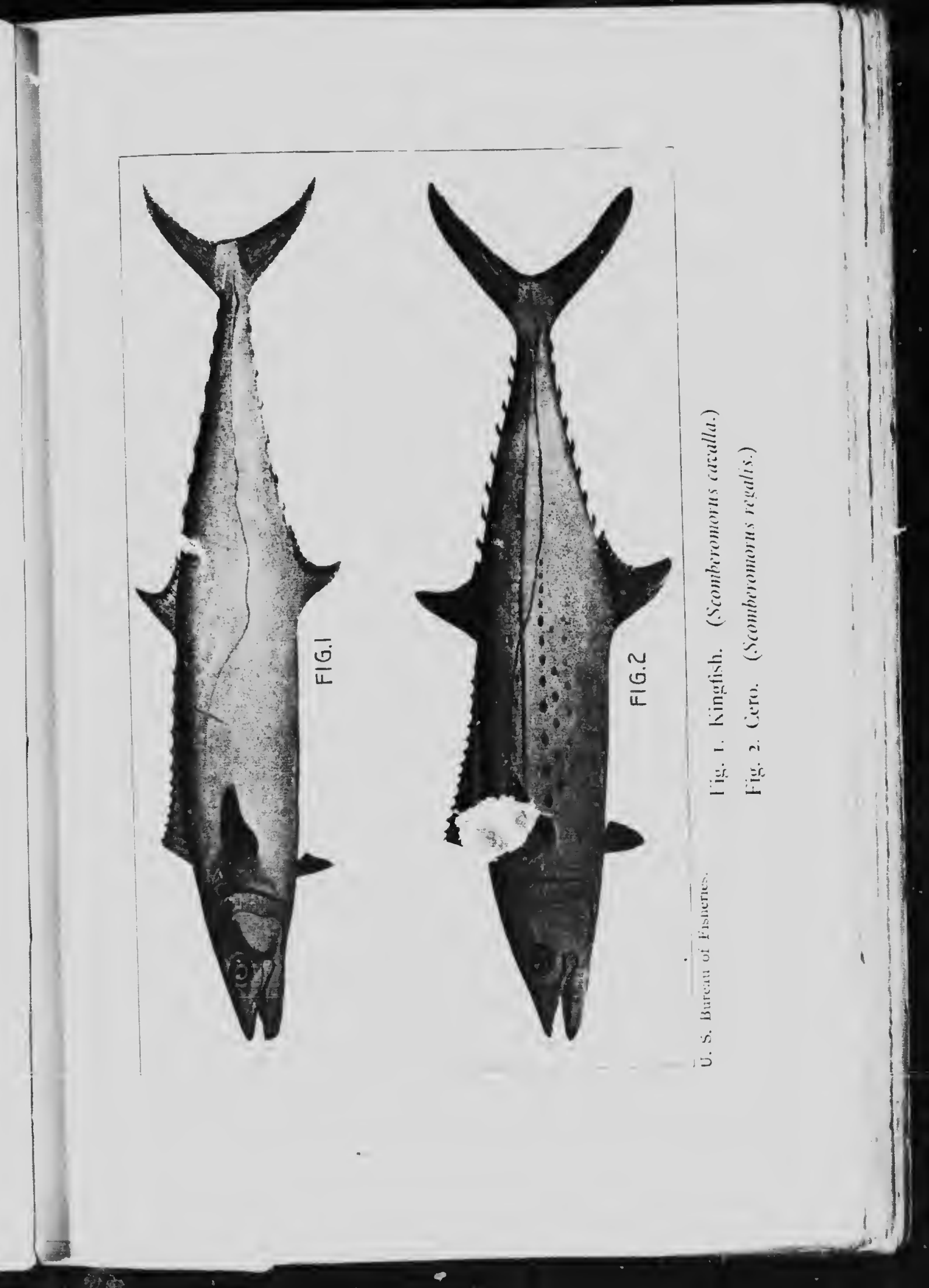




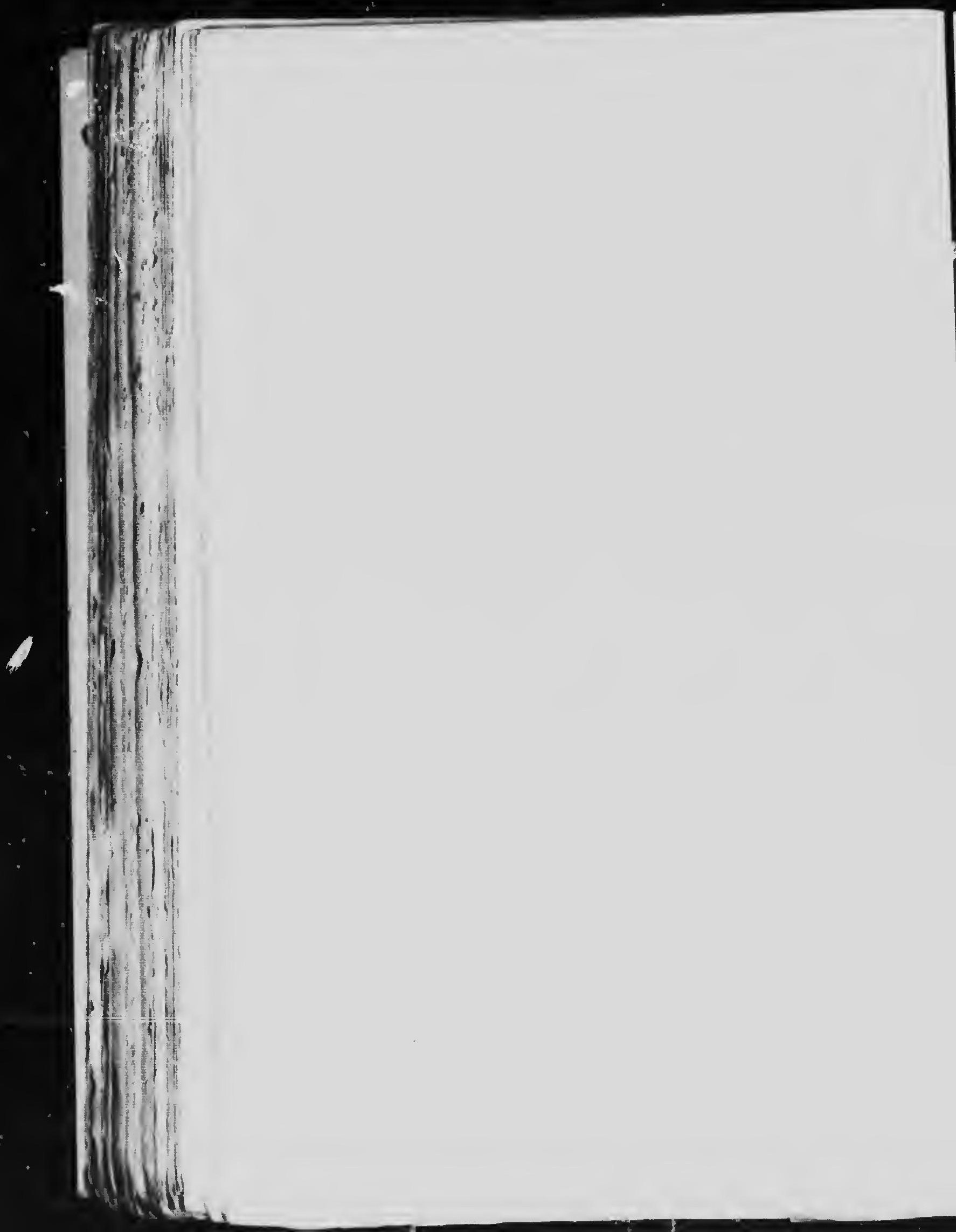




\section{Florida Fish and Fishing}

very gay and bizarre attire; their coats, like Rag-Time Dude Joseph's, being of many colors. They also bear more aristocratic names, as witness: John Paw, Nassau, Hamlet, Cabrilla, etc. But the dude of the family is the niggerfis', which is a rag-time dandy, always in full dress for a cake walk.

The snappers are worthy members of the finny race. The red snapper is the most widely known, commercially, being shipped from Pensacola and Tampa to all Northern cities. It is a large, handsome fish, dressed, like Mephistopheles, from siout to tail in scarlet. As it is taken cnly in deep water, on thi snapper banks, by hand lines, it is of no importance to the angler. But the gray, or mangrove snapper, is a wary, active fish and good game. It lurks under the mangroves and must be fished for cautiously, when it will rise eagerly to the fly, and on light tackle is no mean adversary. Its usual weight is from one to three pounds.

The lane snapper, dog snapper, yellow- The Gay tail and schoolmaster, are fine pan fishes, clothed in royal raiment, and frequent the 


\section{Favorite Fish and Fishing}

channels amid the coral reefs near Key West, where they are readily taken with sea crawfish bait. The muttonfish is larger and an esteemed table fish, and with the other snappers is like the lilies, of which we are told, "Solomon in all his glory was not arrayed like one of these." It is a genuine pleasure to the observant angler to capture one of these fish, if only to gaze upon its beautics, and watch the play of prismatic colors as reflected in its gorgeous attire. Fishing with light tac'sle for these lovely denizens of the coral banks, with one's boat rising and falling on the rhythmic swell of the pure emerald green sea, is both a joy

The Ladyfish and a delight.

(Albula vulpes)

The hightlyers, or finny acrobats, are the tarpon, kingfish, ladyfish and ten-pounder. The first-named is so well known that further mention here is unnecessary, and moreover I have accorded it a special article, for it trots alone in its class; but while the ladyfish and ten-pounder are only a couple of feet in length, they are still worthy to be named in connection with his silver majesty. 


\section{Florida Fish and Fishing}

They are built for aërial as well as for submarine navigation, and dart so quickly from one element to the cther that it is somewhat bewildering to watch one at the end of a line. Twenty-five years ago I compared the ladyfish to a " silver shuttle," for such it appeared in its efforts to escape when hooked.

The angler visiting the region of Biscaync Bay will find considerable confusion

The Ten-

Pounder (Elops saurus) existing, not only among Northern tourists, but among the residents, concerning the proper identification of the ladyfish and tenpounder. They are two silvery, spindleshaped fishes that resemble each other very closely in size, general outline and appearance, and are known as the ladyfish or bonefish, and the ten-pounder or bony-fish; the latter is also sometimes called Jack Marrigle in Bermuda, and both fishes are not infrequently alluded to as "skip-jack." They are game-fishes of a high order and of equal degree.

The confusion alluded to has been aired in our angling papers for several years, 
Favorite Fish and Fishing

Confusion of Names

Of Ancient Age and Lineage

sometimes with photo-illustrations of the fishes concerned, which, however, only served to make confusion worse confounded. For instance, I remember one communication with an illustration of the ladyfish, but which was stated in the text to be the bonefish and not the ladyfish.

This confusion of names arose originally from the fact that the names bone-fish and bony-fish were applied indiscriminately by native fishermen to both ladyfish and tenpounder; indeed, the names ladyfish, tenpounder, and their synonyms bonefish and bony-fish date back to our earliest history. In Natal it is called "springer."

Their scientific names were both bestowed by Linnaus more than two hundred years ago. Catesby, in 1737 , called the ladyfish of the Bahamas "bonefish," while Captain IVilliam Dampier, one of the early explorers, called the bony-fish of the Bahamas "ten-pounder." While the two fishes are both allied to the herring tribe, they belong to different families, though the young of both species undergo a metamor- 


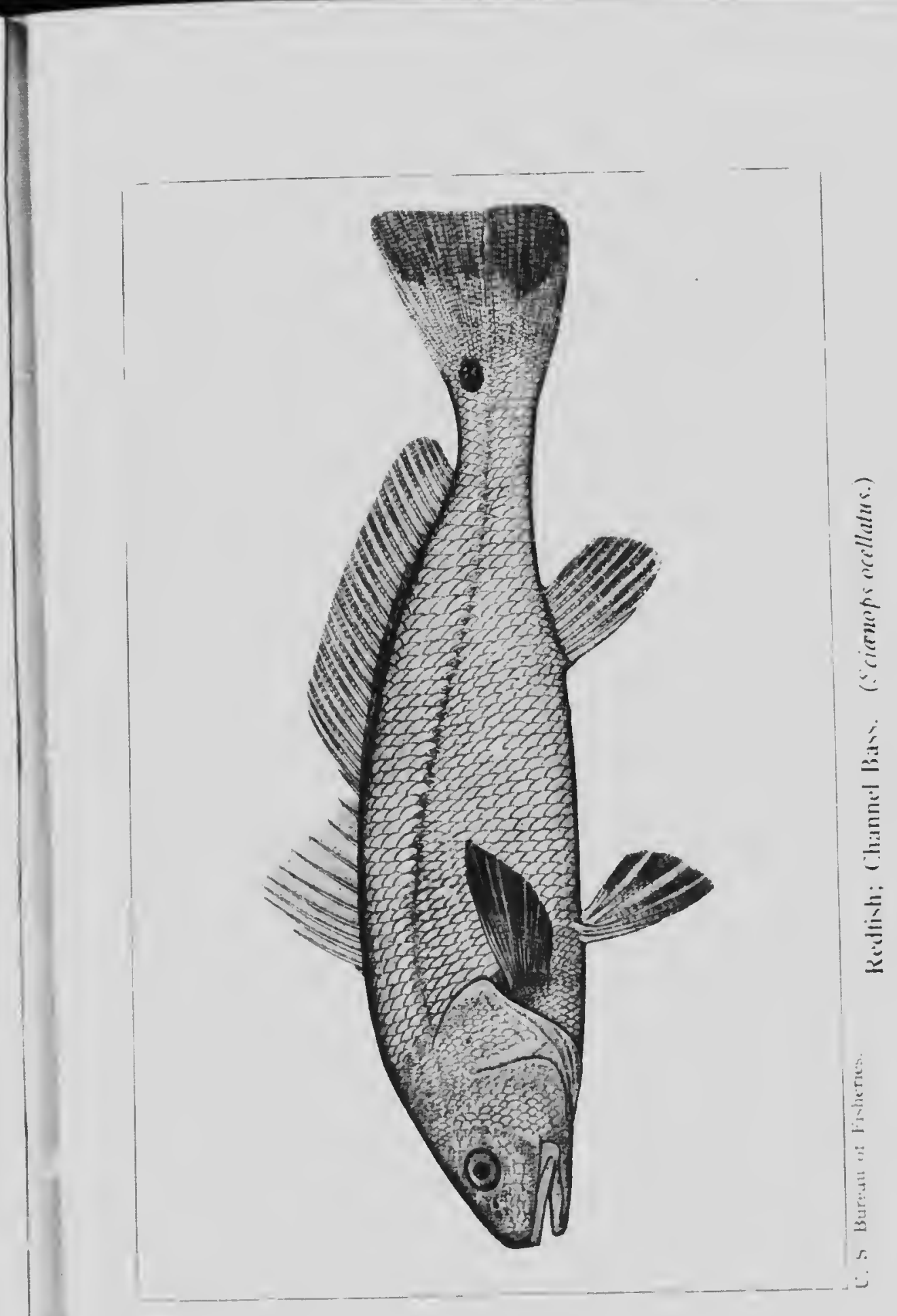




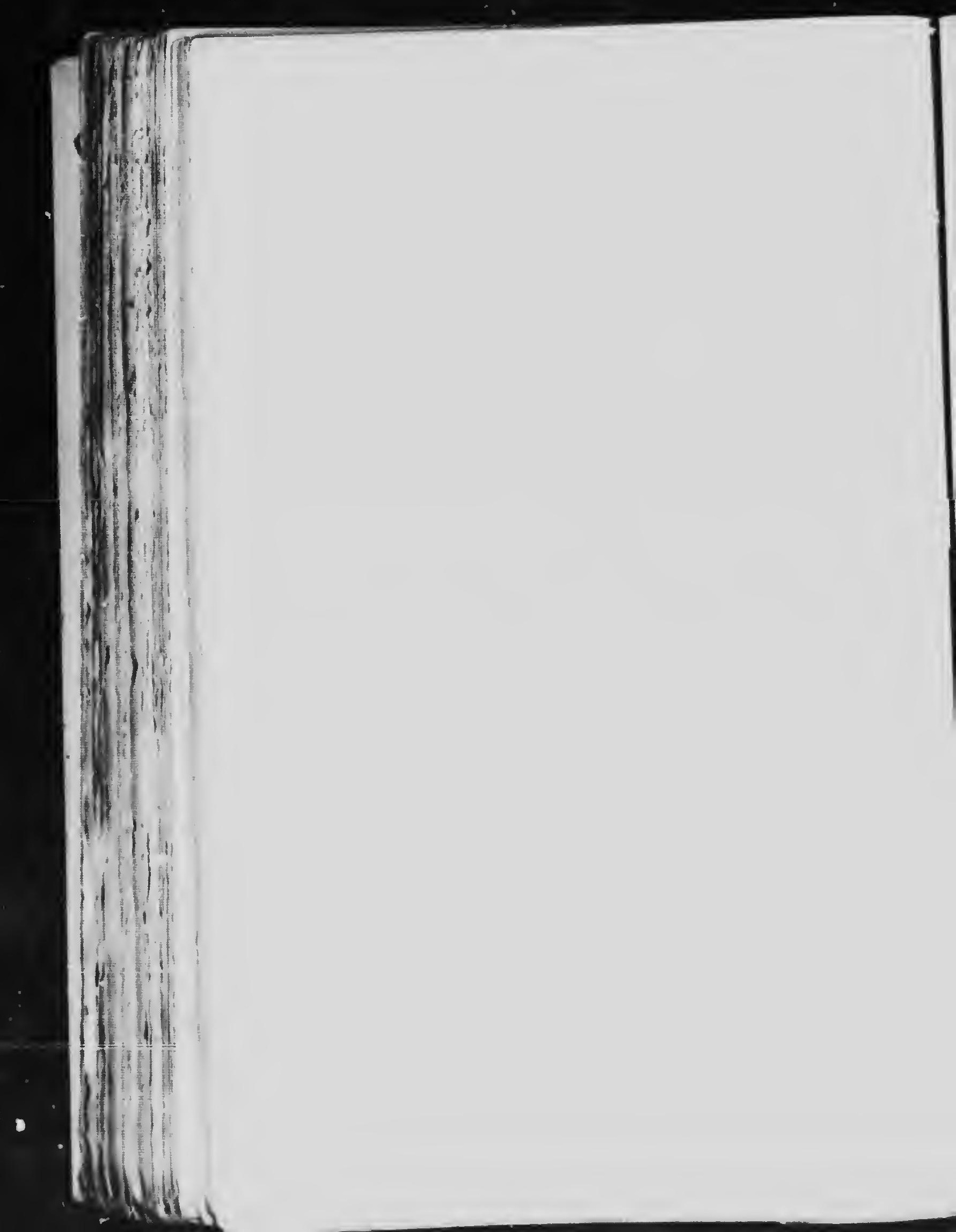




\section{Florida Fish and Fishing}

phosis, or pass through a larval stage, in which they appear as ribbon-shaped, transparent bodies, totally unlike their parents.

As just stated, they belong to entirely Nomenclature different families. The ladyfish (Albula vulpes), or bonefish, as it may be called, is the only fish in its family (Albulida), while the ten-pounder (Elops saurus), or bony-fish, belongs to the tarpon family (Elopida), and like the tarpon has a bony plate between the branches of the lower jaw (hence bony-fish), which bone does not exist in the ladyfish. The proper identification of the two fishes is really easier than to distinguish between the two species of black bass, or to differentiate a pike from a pickerel.

The most pronounced difference is in the Differentiation conformation of the mouth. The ladyfish has an overhanging, pig-like snout, the mouth 'g somewhat underneath, while the te nder has a cirminal mouth, that is, with the upper anu lower lips meeting in front, the same as in most fishes. The scales of the ladyfish are nearly twice as 


\section{Favorite Fish and Fishing}

large as those of the ten-pounder, otherwise, as to the general contour, silvery appearance, and shape and disposition of fins the two species are much alike to the ordinary observer. So, if they are called ladyfish and ten-pounder, their proper names, and not bonefish or bony-fish, the confusion at once disappears.

Tools and Tackle

Black bass tackle, the rod noi less than eight ounces, is sufficient for either ladyfish or ten-pounder. Sproat hooks, Nos. I to 3 , on long gut snells if no leade - is used, are large enough, for both fishes inave rather small mouths. Usually no sinker, beyond a small box-swivel, is required when fishing on the flood tide at inlets, unless the tidal current is very strong, when it may become necessary to use one of suitable weight. The best fishing is at the mouths of inlets duri ig the flood tide, when the fish are feeding on beach fleas, pompano shells, shrimps and other crustaceans which roll in on every wave, and are the best baits to use. A small fish, an inch or two long, also makes a good bait. The smallest casting-spoor, with a I 56 


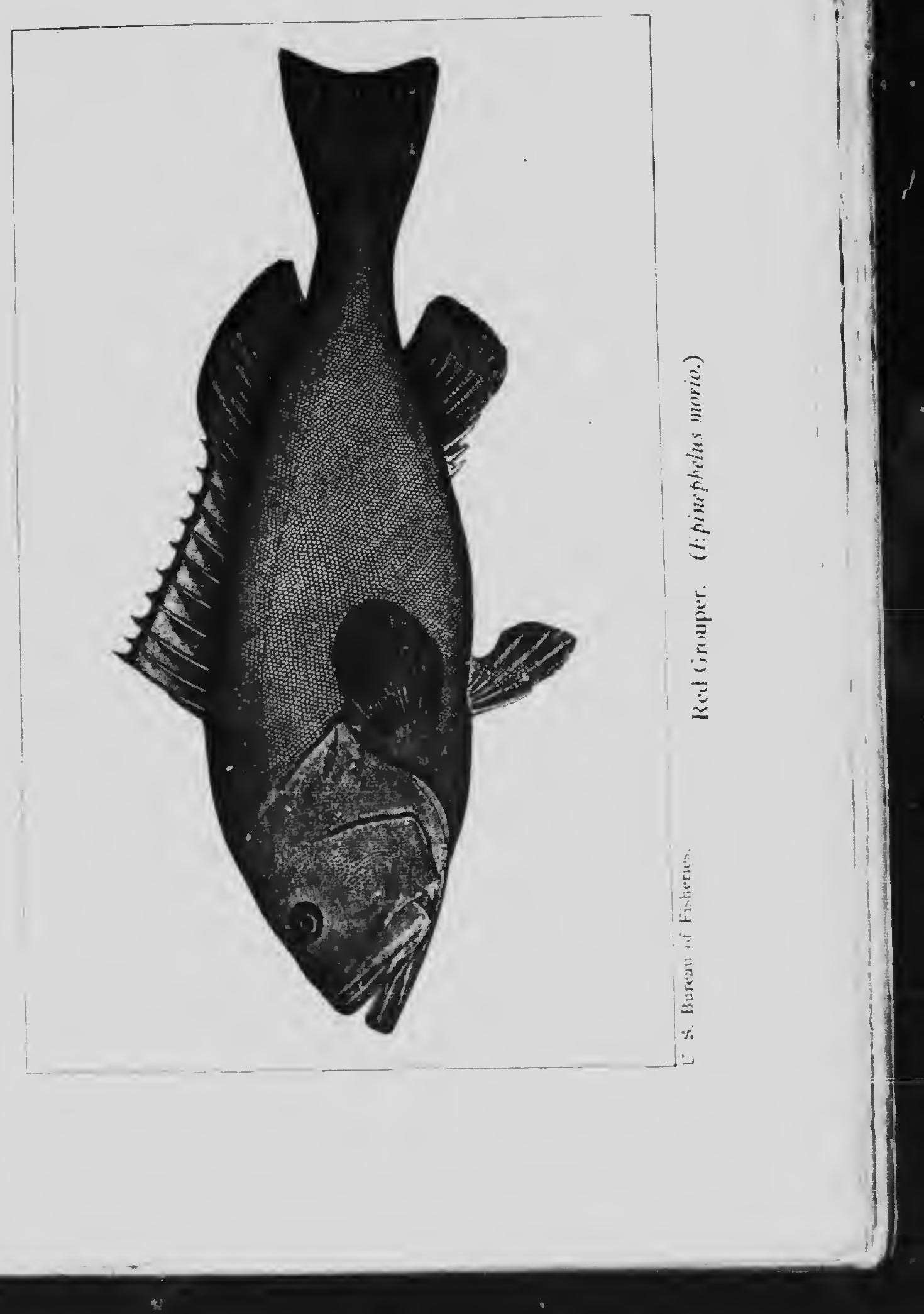




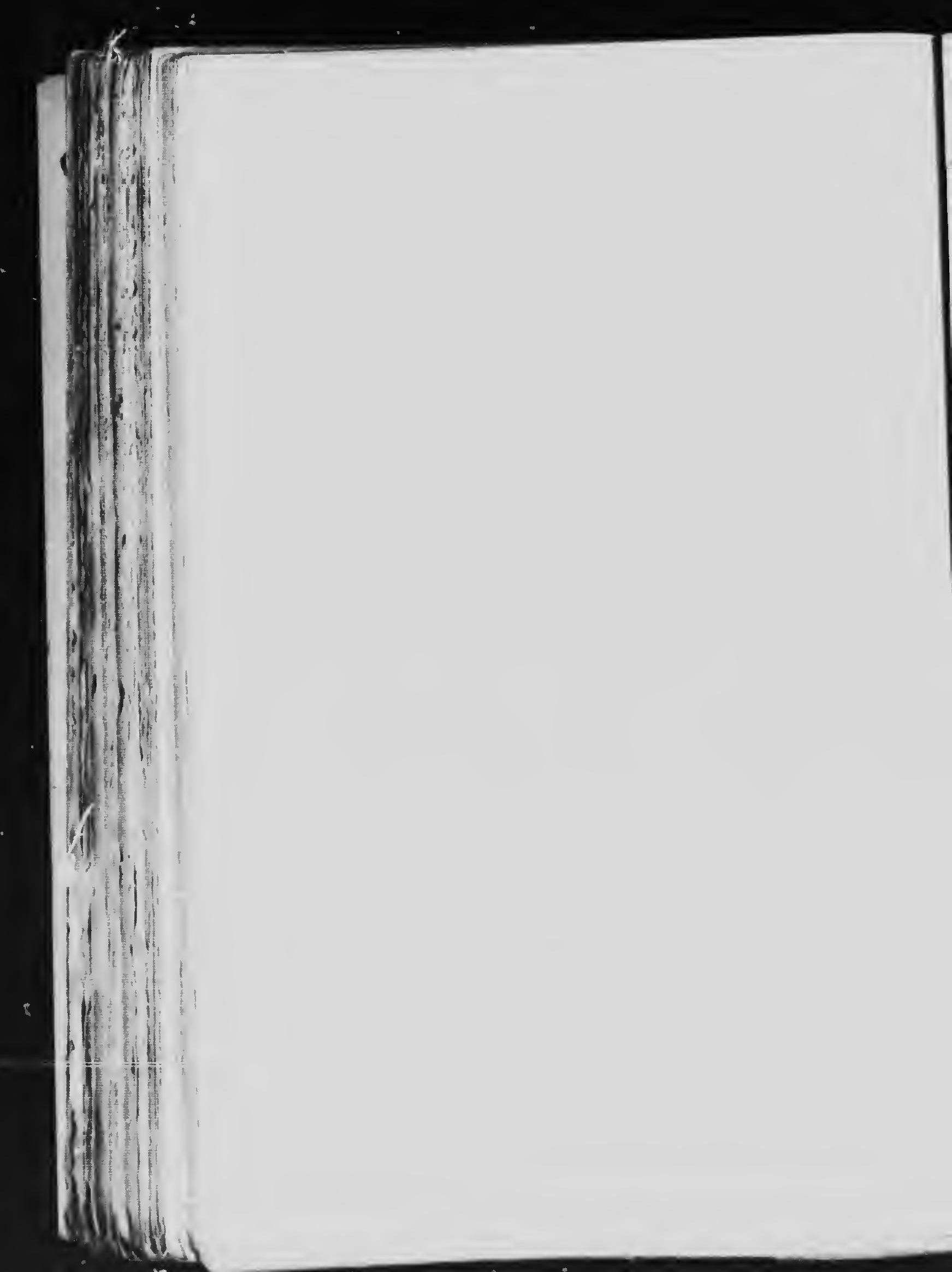


Florida Fish and Fishing

single hook, or a small shell squid, may often be employed with advantage, as well as a small, bright artificial fly.

The fishing may be practiced from a boat anchored just within the inlet, or from the sand-spits at its mouth. At other stages of the tide, especially at high ater slack, good fishing may be had in the shallow water of grassy flats and sandy shoals, by making long c?sts, for in such situations these fishes are quite shy.

The snook is a good game-fish, strong and active, rises to the fly in shallow water, and will take any kind of fish or crab bait, or undecimalis) the trolling-spoon. It is shaped somewhat like the pike-perch, with the flattened head and jaws of the pike minus its sharp teeth. It is attired in a silvery mantle with a broad, black stripe running along the side from head to tail. It is a fair food-fish if skinned instead of scaled. It is known as snook on the east coast, and as rovallia on the west coast, a corruption of its Cuban name, robalo. It grows to two or three feet and twenty to thirty pounds. Heavy 


\section{Favorite Fish and Fishing}

The Jewfish (Garrupa nigritis)
A Good FoodFish black bass, or light striped bass, tackle is necessary to withstand its fierce rushes when hooked.

And last, but not least, comes the jewfish, the Gargantua of the water, though clothed in a vesture of modest blackish gray. It is somewhat like a colossal black bass in contour and appearance, and in fact a closely allied species, the jewfish of the Pacific, is called black bass on the coast of southern California. The David who slays this Goliath of the deep should be proud of his achievement, if it is killed on the rod. From twenty to one hundred pounds is about the usual limit of rod-fishing for the jewfish, though a few have been killed on the rod upward of two hundred or three hundred pounds at Catalina Island on the California coast.

At any deep inlet of the west coast of Florida, or about Key West, they may be found, but never in great numbers. Unlike the tarpon, the jewfish is an excellent fish for the table, and is greatly esteemed at Key West, where it is cut in steaks and fried 158 


$$
1
$$




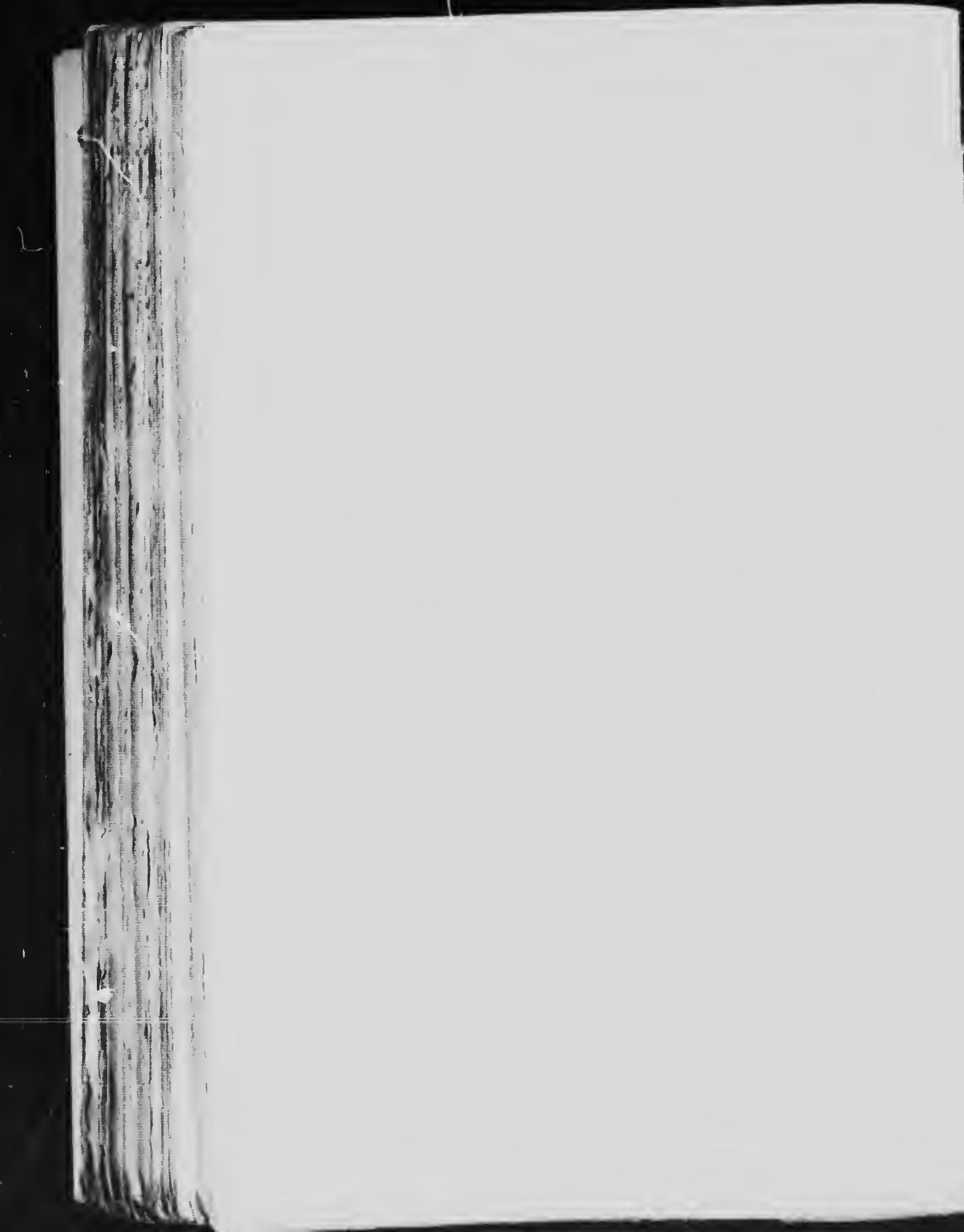




\section{Florida Fish and Fishing}

in batter, when it is very toothsome. I Some Big Ones helped capture one on a shark line at Jupiter Light on the east coast in 1878 that weighed three hundred and forty pounds on the light-house steelyard, and United States Senator Quay was a witness to the weighing. I was also particeps criminis in taking on a shark line anothei that weighed three hundred pounds, at Little Gasparilla inlet, on the Gulf coast, in the same year. And farther up the coast, at Gordon's Pass, near Naples, I killed a number on the rod that weighed from twenty to sixty pounds. A decade ago the south shore of this inlet, under the palnetto trees which grew on the steep bank, was a noted place for jewfish, and much frequented by Col. Haldeman and other Kentucky gentlemen who had winter residences at $N$ aples.

Another jewfish, a tropical species (Promicrops itaiara), growing even larger than the one named, is also found in Florida waters.

I do not mean the universal and ubiqui- Catching tous sucker so well known from Maine to 


\section{Favorite Fish and Fishing}

California, but the so-called shark-sucker, suckfish or remora. Perhaps every genuine American boy has exercised his proud privilege of catching suckers in the glad springtime, and some have doubtless continued the sport in later life in Wall Street and other similar fishing localities. But very few have ever caught the shark-sucker or remora. To be exact I never knew of any one but myself who ever took one with hook and

How It Happened

The Remora (Remoria remora) line.

It happened in this way. My boat was anchored in Sarasota Bay, Florida, when one day I was examining the pintles and rudder hinges before sailing, when I noticed several remoras attached to the stern of the ressel. With a hook and hand-line and venison for bait I caught them all, four of them, in less than four minutes, for the were exceedingly voracious. When the bai was dangled near one he inmediately lef his anchorage and seized it.

The remora is one of the most interes ing fishes known to science. Its first dors? fin is developed as a sucking disk of a 160 


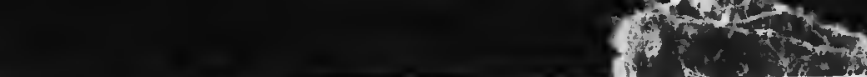

ucker,
enuine
privi-
pring-
ed the
other
wave
emora.
ne but
ok and
at was

, when les and n I nohe stern and-line all, four for they the bait tely left interestst dorsal $\mathrm{k}$ of an
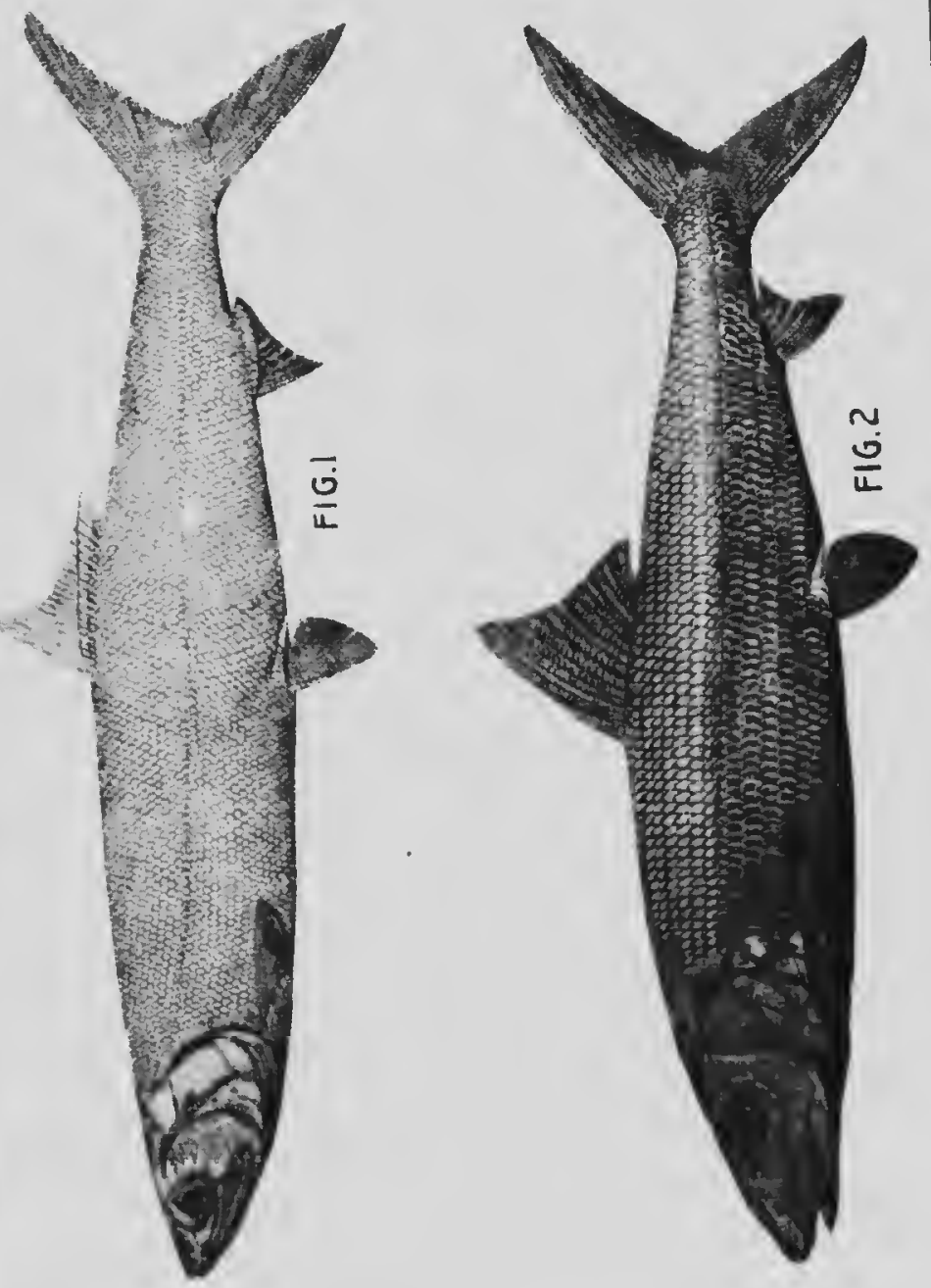

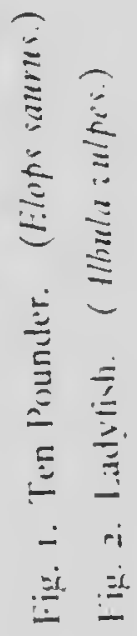




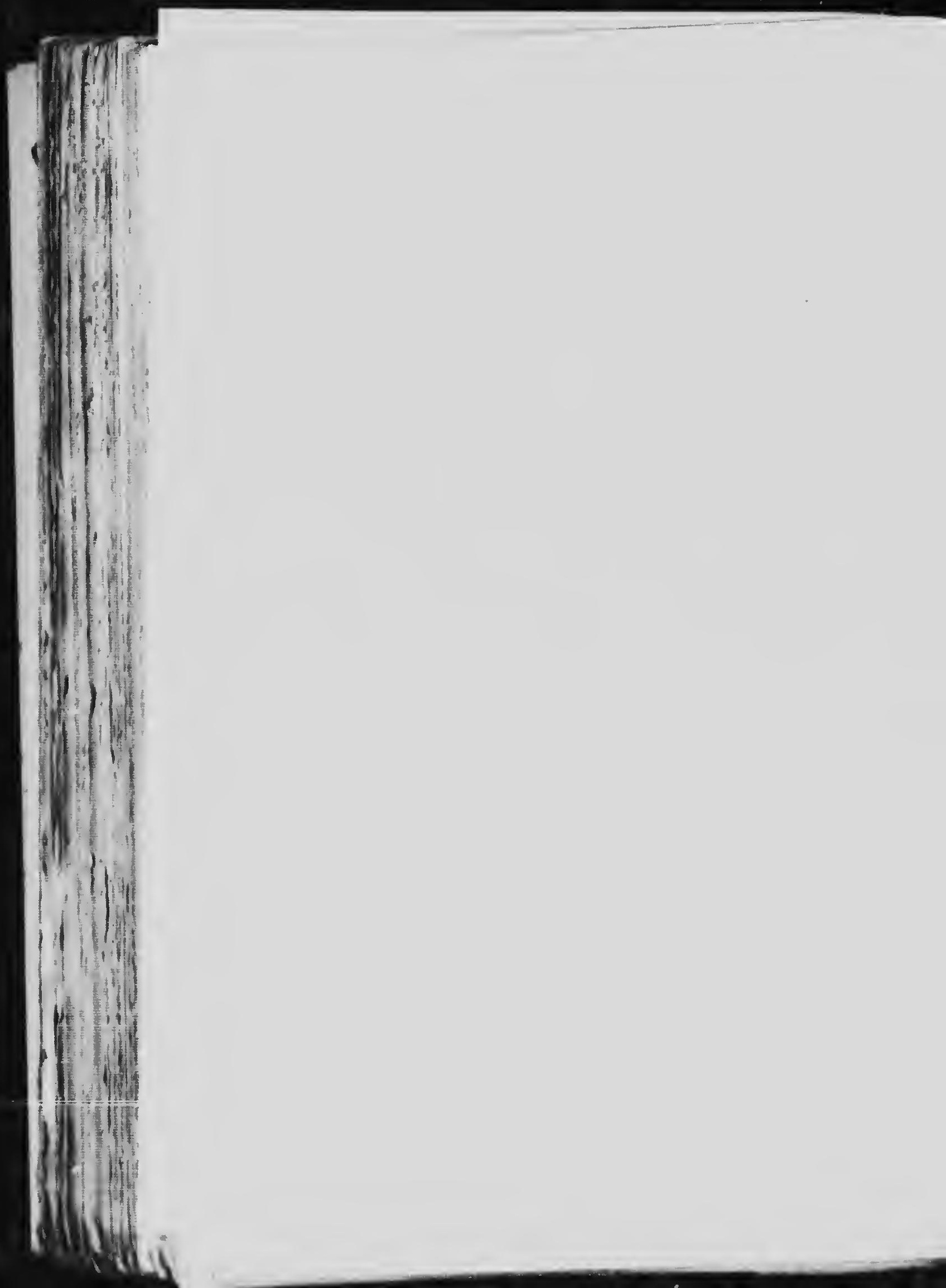


Florida Fish and Fishing

oval shape on the top of the head and nape. It is formed of a series of thin plates, or A Convenient Device laminæ, overlapping like the slats of a Venetian blind, and by which it can firmly attach itself to a comparatively smooth surface. I have seldom caught a shark or a ray that did not have one or more attached to its skin. ' a shark seizes his prey, and is cutting, $r$ with his terrible teeth, the remora is $q^{1}$ ick to discover any fragments of the feast and profits by it, when it again returns to its anchorage. It does no harm to the shark, for it is not truly parasitic, like the lamprey, but uses its host as a means for transportation and profit, like the politician in the band wagon.

The remora is easily removed from its attachment by a quick, sliding motion, but As a Fishing Device resists a direct pull to a remarkable de!rree. Owing to this fact the natives of tropical countries are said to utilize it for catching fish, by fastening a ring and line to its caudal peduncle and casting it into the water to become 'ttached to other fisn, when both are hauled in. I had often read I 6 I 
Favorite Fish and Fishing

of this, and once I tried it, but caught only a loggerhead turtle of twenty pounds. The strain on the remora, however, was so uemoralizing to its physical economy that I was fain to kill it.

Phosphate Fishing
And while on the subject of queer fishing I recall another instance. Commander Robert Platt, formerly of the U. S. Fish Commission steamer Fish Harik, and I were once seining in Peace Creek, above Punta Gorda, Florida. The crew hauling the long seine were much bothered and i.in. dered by quantities of ragged rock getting entangled in the seine. This afterward proved to be phosphate rock of a valuable grade, which was mined from the creek, the land on each shore having been purchased for a song by some enterprising party. When in Washington a year or two later I met Captain Platt, who, holding up his hands, exclained:

"Do you know what tha ragged rock in Peace Creek was?"

"Yes, phosphate rock of a high quality."

"Well, do you know what precious 162 
Florida Fish and Fishing

chumps we were not to have purchased the A Missed land on each side of the creek?'

Opportunity

"Yes, Captain 'Bob'; and I met a gentleman on the train yesterday who was the party who bought it. He was on his way to Washington to have Boca Grande made a port of entry for shipping the stuff to Europe. He also informed $m$, that he had sold a third of his interest for sixty thousand dollars!'

"Well, I'm d-lighted to hear it. Just our luck!"

"Yes, Captain Bob," I returned, "it was another missed opportunity. But we were not looking for phosphate rock or goldfish; we were simply looking for ripe mullet. It all depends on the viewpoint."

I was once cruising in Barnes Sound and spearing the hid for a pilot Captain Bill Pent, of Key Jumbos West, who was fully acquainted with the numerous shoals and inud flats of those shallow waters. Oir experiences, as might be imagined, were both novel and varied. After seining the cores and shores for specimens of the smaller fishes, we would give I 63 


\section{Favorite Fish and Fishing}

Florida

"Grains"

Some Big Fish 


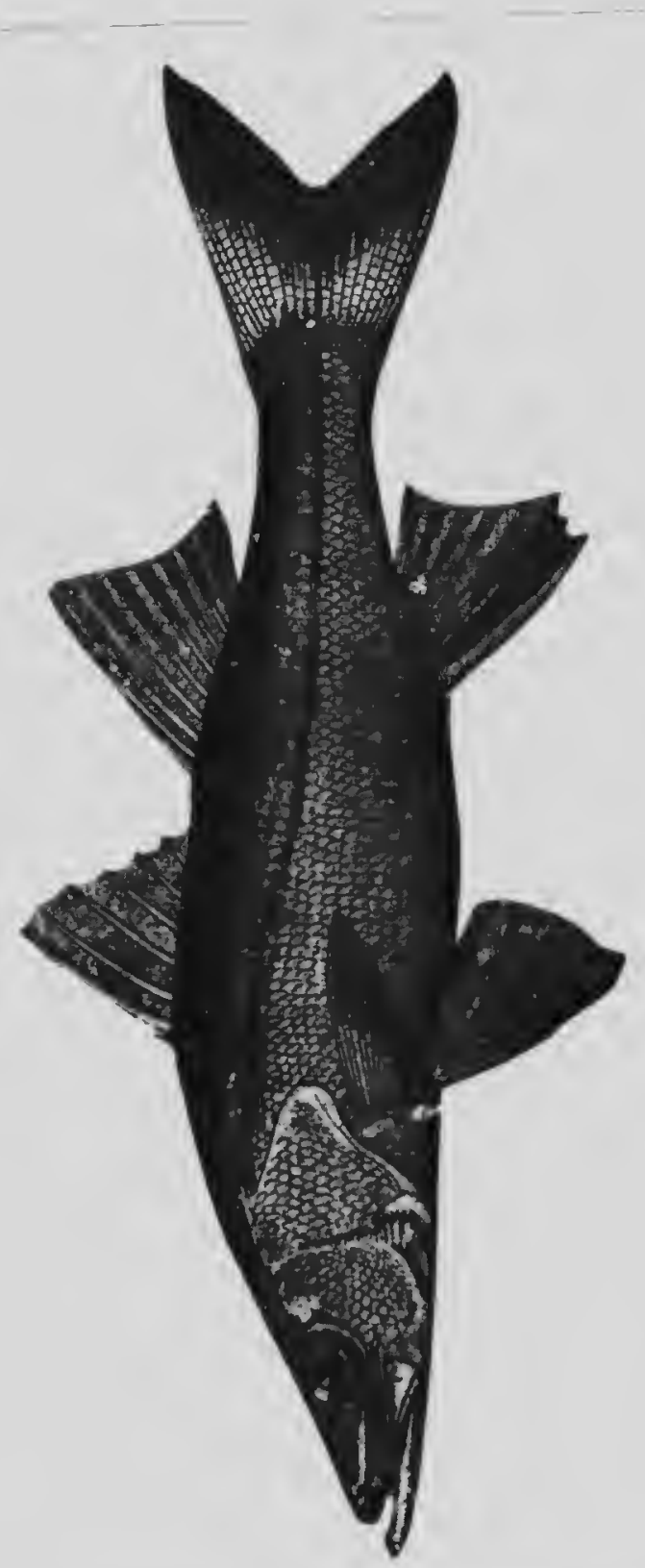

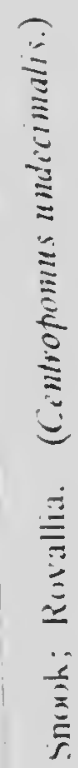

vas

ns, 


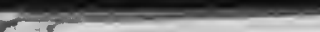
1) $f$

1) 4 ) 8 1 .

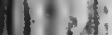

(1).

(1) $\frac{1}{2}$

a)

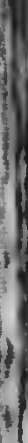

II) II)

$1+1$

in

II)

()$^{1}$

()

(I)

111

111

14

U.

|I

P.

[F

| $1+1$ 


\section{Florida Fish and Fishing}

eight feet across the pectoral fins-I have seen them of twenty. Following the lead of Victor Hugo, the octopus is often called " devil-fish," but the name rightly belongs to this fish, the largest of the rays (Manta birostris). The floundering and struggling of one Strenuous of these aquatic giants, in shallow water, was something to be remembered, while the erratic pitching and lunging of the dory as it followed the lead of the finny motor was, to say the least, exciting. These large fishes were towed ashore, killed outright and dissected, in order to ascertain something in relation to their diet and time of spawning.

One da: we saw a porpoise in very shal- Porpoise low water playing with her two calves, which were about three feet long. The water scarcely covered them. Being somewhat curious as to the result, I took the rifle and sent a bullet ricocheting across the water just behind her. In great alarm she gathered a calf under each flipper, and the way she made the water fly with her fluked I 65 


\section{Favorite Fish and Fishing}

tail propeller in her eagerness to reach deeper water was amusing, but not the less re kable. I could observe her plainly for a hundred yards, and when she at last disappeared in deep water she was still hugging her calves.

A Pretty Baby

The Manatee or

Sea Cow

(Tricbecbis

latirostris)

Once at Mullet Key, in Tampa Bay a man at the quarantine station shot a 1. poise that was floundering in the water. I saw that it was about dead, and procuring a boat I towed it ashore. It was a female and seemed to be gravid. I performed the cæsarian operaticn and found a single baby porpoise nearly two feet long. It was a beautiful animal, the upper half being slate color and the lower half a fine rosy pink. It was sent with other specimens to Washington and a cast made of it.

Another day while sailing in Barnes Sound we ran across three manatees feeding on a plant resembling eel grass. As we kept very quiet we were almost upon them before they discnvered the boat-then they stood not on the order of going, but went at once, and went in a hurry. The wake I 66 



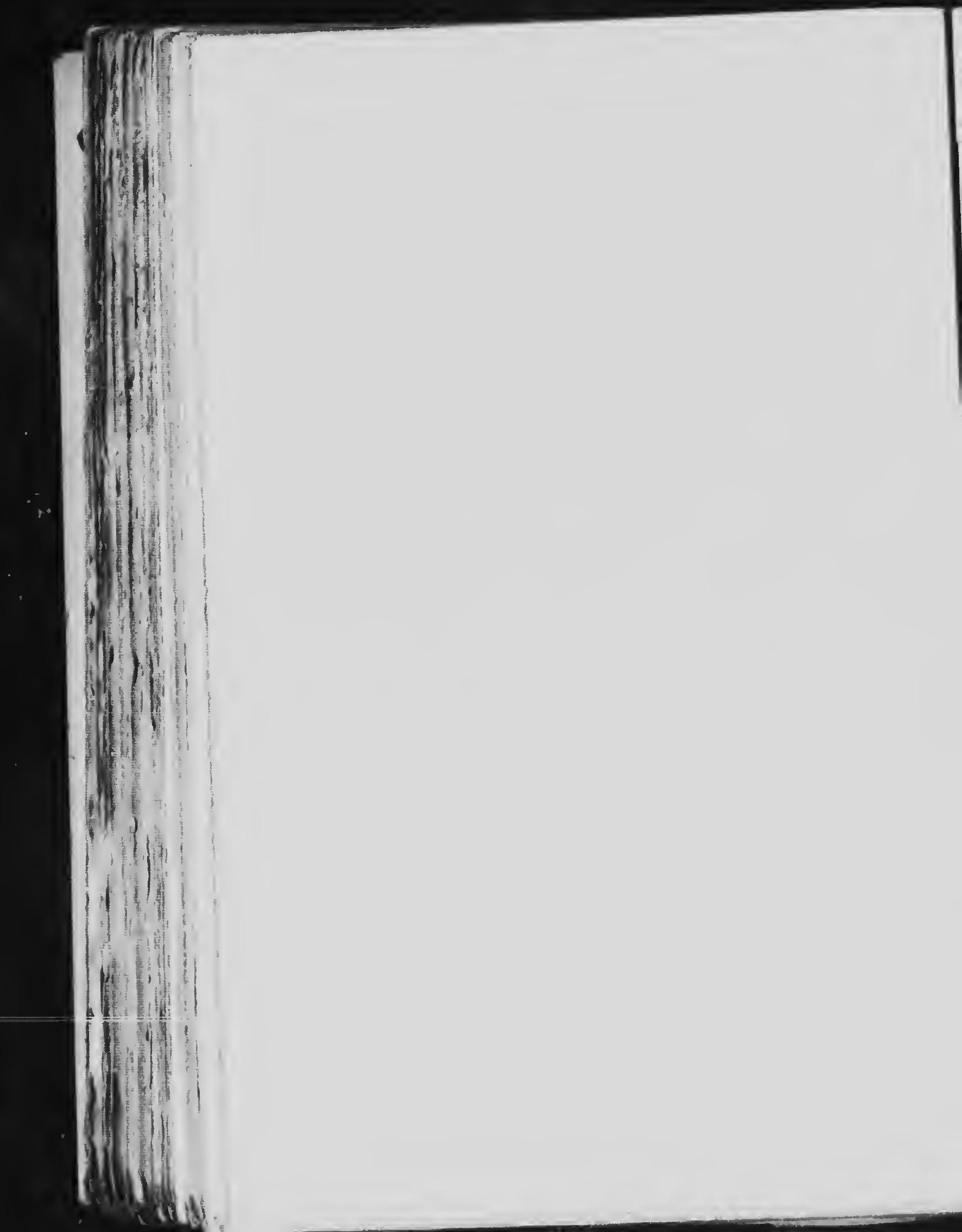


Florida Fish and Fishing

they left in the shaliow water was equal to that of a large steam tug. For such ungainly looking creatures-the body nearly as large as that of a horse-they were remarkably active in escaping, but made a fearful fuss in doing so. I had several times seen manatees in the St. Lucie River, a tributary of Indian River, but nowhere else, and was much surprised to find "th? in Barnes Sound.

About Biscayne Bay the angler will find fishing for large-mouth black bass, bream, etc., on Miami River, and at Arch Creek Keys above, and Snapper Creek below. For saltwater fishing he will have all he can attend to at almost any of the inlets and passes between the keys from Cape Florida to Bahia Honda. Among the best are Bear Cut, Cæsar's Creek, Angelfish Creek, and the channels between Rodriguez, Tavenier. Long, Indian, Mattecumbe, Vaccas and other keys. He will find the various channel fishes, and groupers, snappers, cavalli, kingfish, cero, etc., in addition to ladyfish, ten-pounders and a host of others. If he I 67 
Angling on the East Coast

In the Lagoons

\section{Favorite Fish and Fishing}

visits Cocoanut Grove, my old friend, Charles Peacock, will put him on to the best fishing grounds.

The best salt-water fishing on the east coast is at the various inlets, though good fishing is found also in the lagoons and in the fresh water streams emptying into them. My own experience begins with Mayport at the mouth of St. John's River. Here and at most of the inlets to the south can be found redfish, spotted weakfish or sea-trout, sheepshead, drum, snooks, together with such smaller species as pinfish, pigfish, croakers, flounders, etc.

At St. Augustine there is fair fishing at the inlet and in Matanzas River. Near Ormond and Daytona on Halifax River, and below at Mosquito Inlet, the angler will be well rewarded. Fair fishing may also be found on Hillsboro River near New Smyrna and Oak Hill. Some sport is still to be had in the neighborhood of Titusville, on Banana River and Banana Creek.

Back of Rockledge are lakes Poinsett and Wilder, abounding in black bass. Sev. I 68 

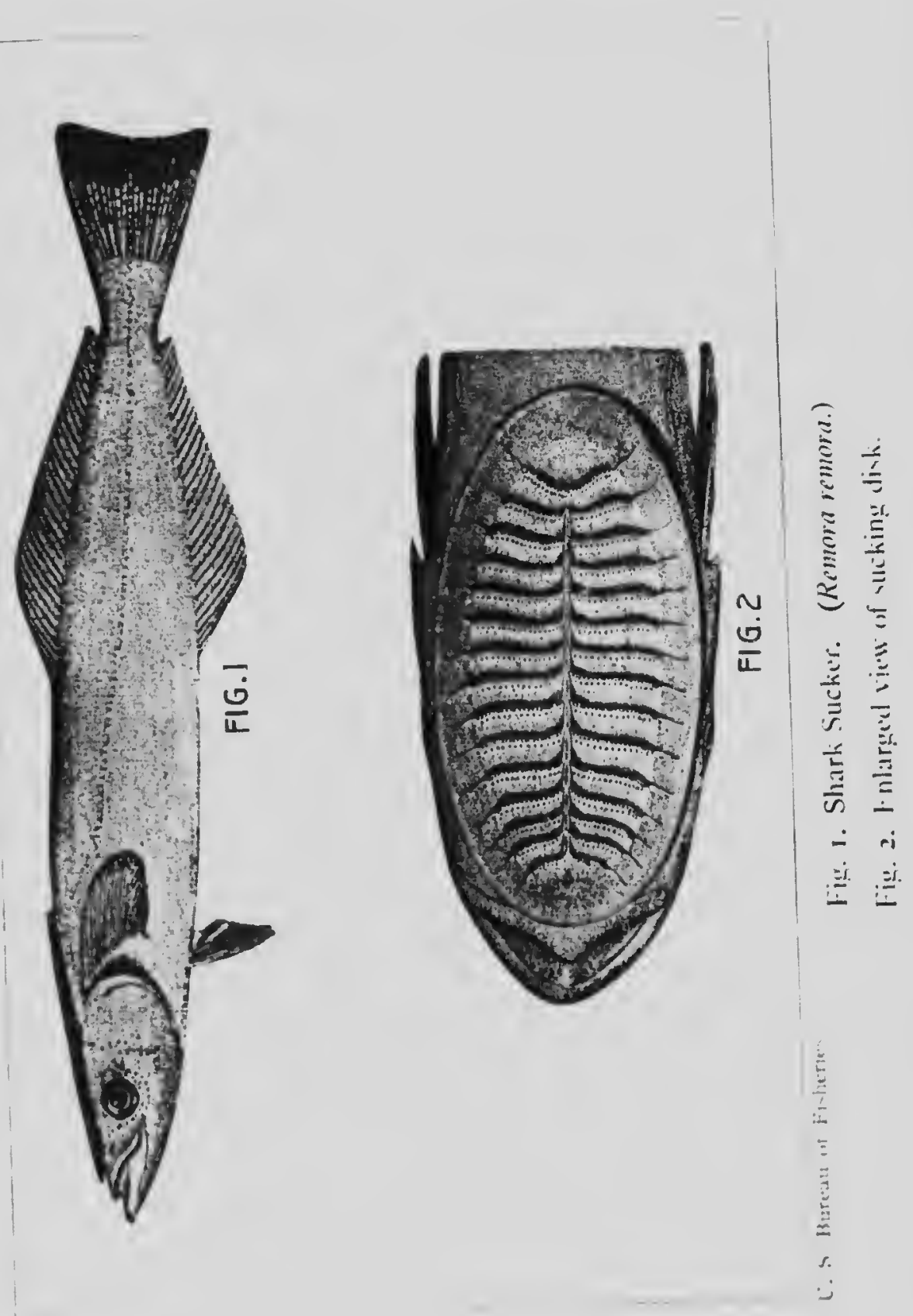


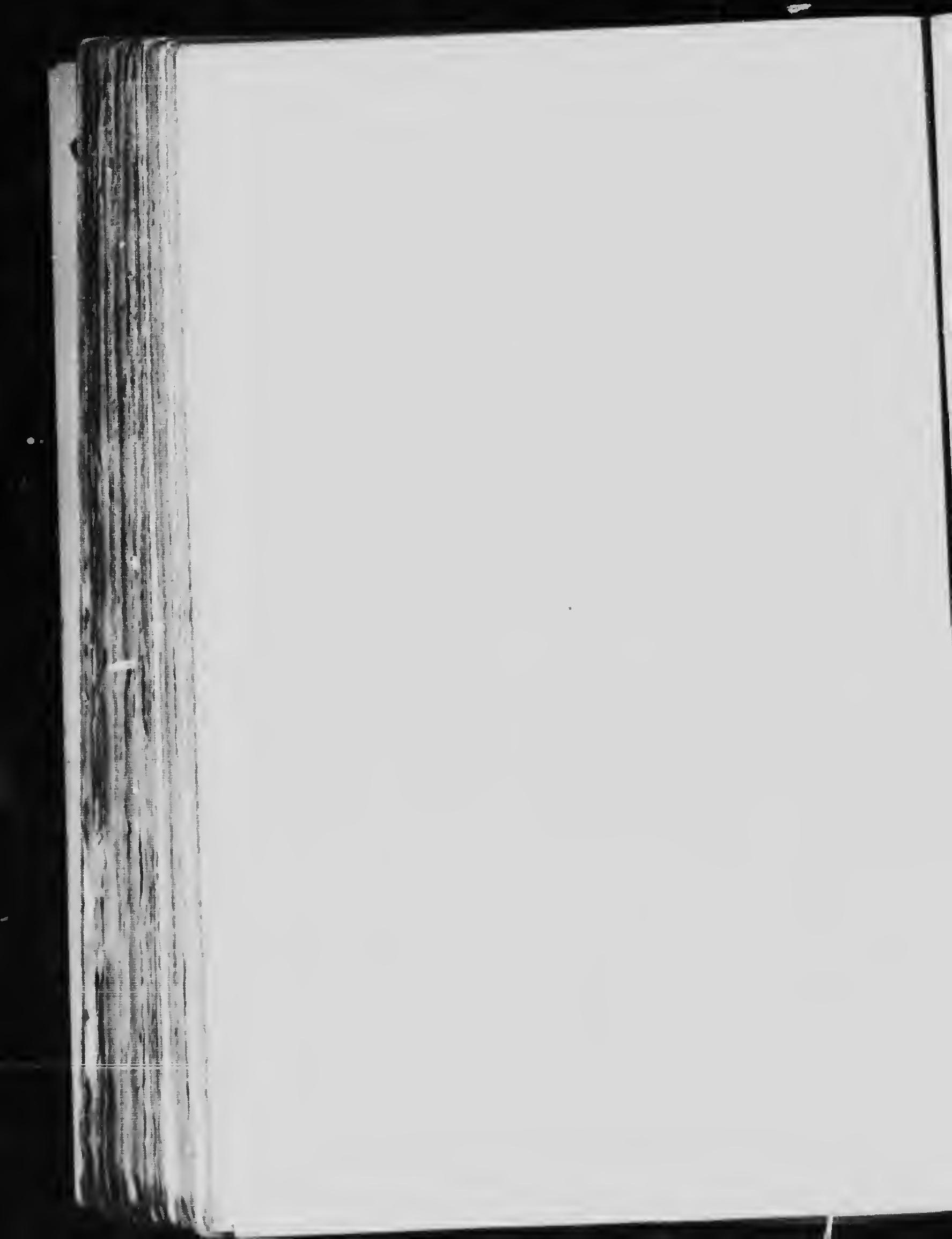


Florida Fish and Fishing

aral places on Indian River furnish excellent fishing, as Sebastian River, Indian River Inlet, Gilbert's Bar, and the waters around Jupiter Light. Farther south, on Lake Worth, Hillsboro' and New River inlets, the fishing is still better, and the fishes larger. St. Andrew's Bay and neighborhood at Angling on the the northern end of the peninsula will not disappoint the angler. Farther south, in the vicinity of Cedar Key, and at the nevsal rivers below-Withlacoochee, Crystal, Iomosassa, Anclote, etc., and at the passes on Clearwater Harbor, the smaller species abound, with occasional big ones. Tampa Bay, Sarasota Bay, Lemon Bay, Charlotte Harbor, Marco and other bays, with their numerous inlets and passes and tributaries are not excelled in the world for the variety and excellence of their game-fishes, large and small.

Tarpon and jewfish require special rods Tools and and reels. The largest groupers, barrackTackle las, amber jacks, bonitos, etc., require striped bass rods, reels and lines, while I 69 
With the

Favorite Fish and Fishing

most of the other fishes mentioned may be easily handled with a good ash and lancewood black bass rod of seven or eight ourses, multiplying reel and corresponding tackle. Sproat hooks of various and suitable sizes cannot be excelled for any kind of Florida fishing, if of the best quality. Nlnost any kind of bait, natural or artificial comes in play-mullet, pilchard or anchory for surface-feeding fishes: crabs, fiddler's, beach fleas and cut bait for bottom feeder:s. Trollins or casting-spoons or spinners can ofter. be substituted for other baits.

During the winter of $1889-90$ I had charge of a scientific expedition to the Gulf of Mexico with the schooner Grampus, of the $\mathrm{U}$. S. Fish Commission. I did the shore work of collecting fishes and fish food along the west coast of Florida, from Biscayne Bay around Cape Sable and northward to Tampa Bay, and secured ne..rly three hundred species of fishes and many crustaceans. For this work I had a mackerel seine boat, thirty-four feet long, rigged with foresail and mainsail. At 


\section{Florida Fish and Fishing}

night I fastened a sprit as a ridge pole between the two masts, and with an awning from the Grampus I housed the boat in completely.

One sunny morning I sailed from John's Pass and entered Gordon's Pass, a few Sport with Jewfish miles south of Naples, about noon. While the men were preparing dinner and getting the seines and collecting outfit in readiness, I had some fine sport with jewfish, running from fifteen to forty pounds, on a ten-ounce rod. A few hundred yards from the mouth of the pass, on the south shore, where the bank is very steep and crowned with palmettos, the water is quite deep, and was a favorite resort for jewfish, as heretofore mentioned.

After dinner we proceeded to haul the A Good Haul iong seine, and just as it was landed, filled with all manner of fishes, four negroes came driving up the beach in a mule cart, two men and two women, to where the seine was being hauled ashore. They leaped out of the cart at once, consumed with curiosity as to the contents of the seine. The 
The Darkeys and the Devilfish

Favorite Fish and Fishing

oldest woman was an immense specimen, weighing about two hundred and fifty pounds, and with a beam as broad as the cart. The other woman was a comely mulatto girl, her daughter. I had just gaffed a small horned ray, a devil-fish, about four feet across its wing-like pectoral fins.

The fat and dusky gargantuan female came waddling down the beach as fast as her short legs could carry her. On seeing the rather formidable and frightful looking ray, she recoiled in horror and exclaimed:

"Good Lawd! Wat is dat ting, mistah?"

"That's a devil-fish, Auntie," I replied.

"Fo' de lan's sake! It sho' luks lak de debble! Luk, Rastus; luk at his ho'ns and tail!"

Then turning to her daughter, she said: "Go 'way, honey: don't come anigh dat ugly varmint; he sho' swallow yo' or prod yo' wid his ho'ns."

I assured her and the other terrorstricken darkies that no harm would befall then provided they did not approach too 

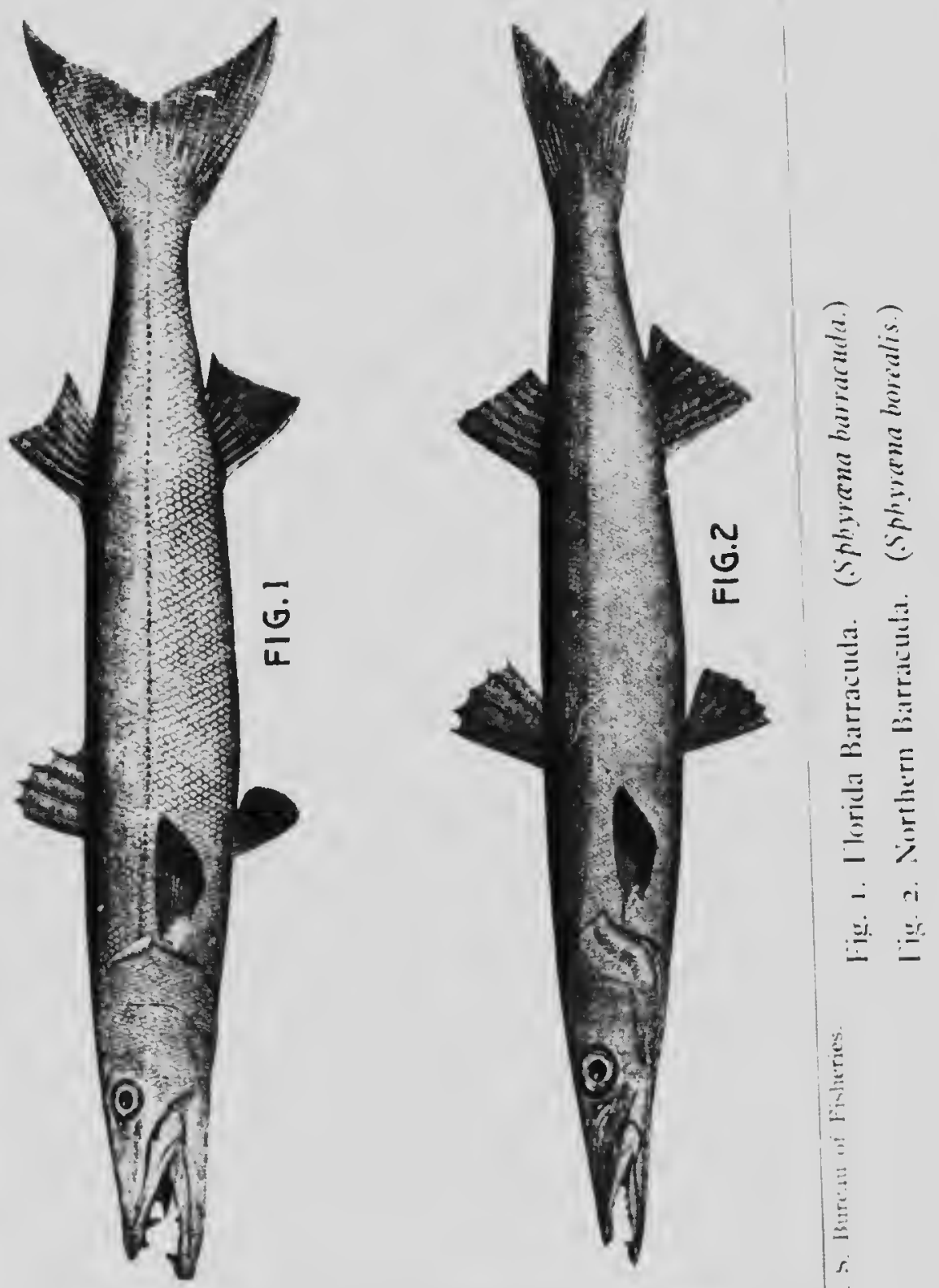


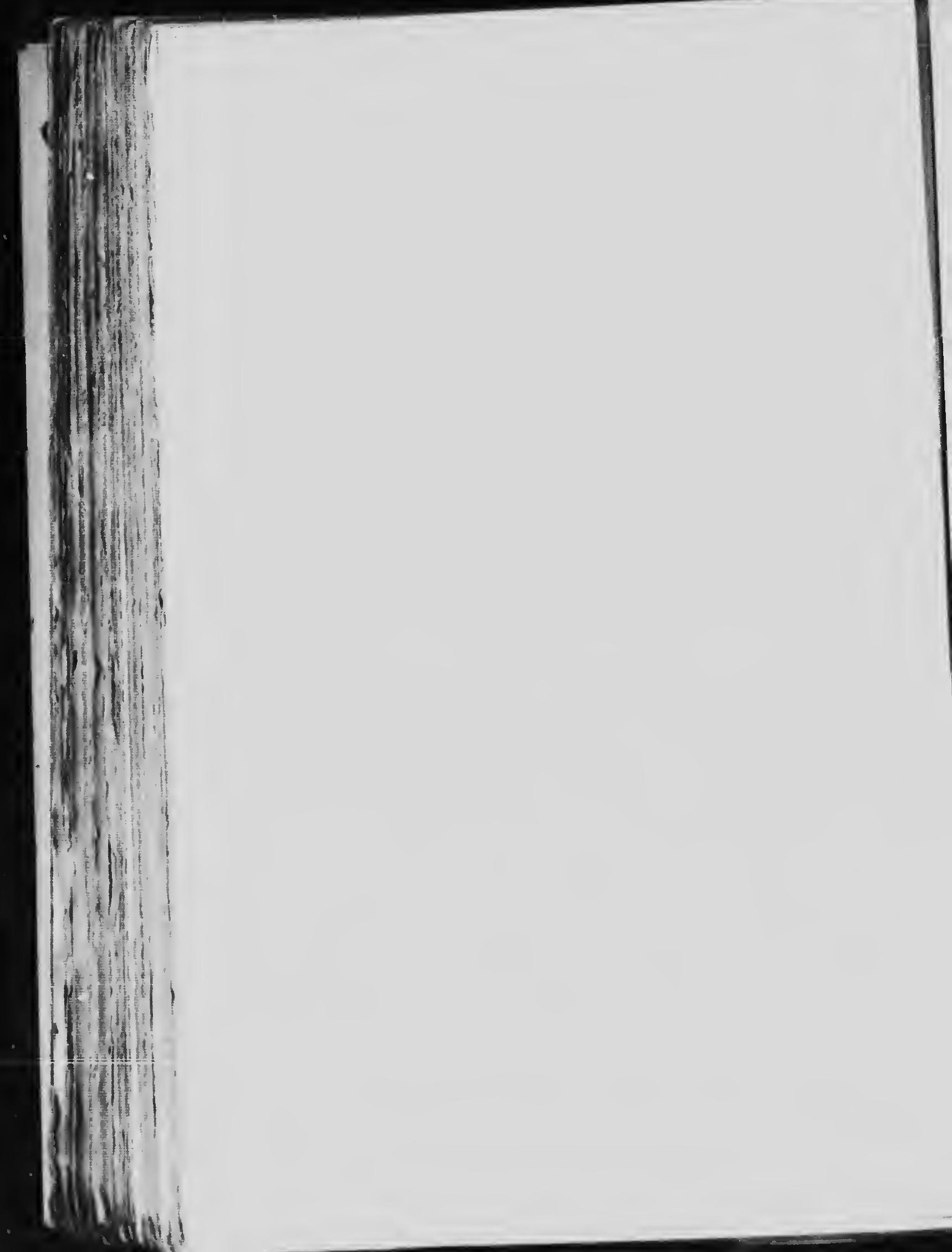


Florida Fish and Fishing

near. Turning to the fat woman, I asked: "When did you leave Kentucky, Auntie?"

"Good Lawd, mistah! How'd yo' know I fum Kaintucky? You must be cunjah man."

"Why, Auntie, as soon as you opened old Kentucky your mouth I knew you were from Kenlucky; I'm from Kentucky myself," I answered.

" 'Deed, honey, I'm pow'ful glad to see yo'," she said. "Why, dar's lots o' people fum Kaintucky up to Naples. Kurnel Haldeman and Gen'l Sarah Gordon WiIlams is bone dar; and Miss Rose, Pres'dent Grove Cleveland's sistah, she dar, too, at de hotel." Then she added, "I'm de cook for Miss Lizzie M'Laughlin; she keeps de hotel."

It seemed that the cook and her party $\mathbf{A}$ Good Catch had come down to the pass to fish, but as I gave them more fish than they really needed, they concluded to return at once to Naples, especially as the jolly cook declared that, "Dat debblefish dun spile my apperite fo' fishin'."

173 
A True Angler

The Founder of Naples

Favorite Fish and Fishing

I handed my card to her, with the request that she take it to Colonel Haldeman, or General " Cerro Gordo " Williams. T'iey departed in gre glee, but with furtive glances at the devil-fish on the beach. As they started off, the corpulent cook shouted:

"Good-by, mistah; hopes to see you soon. Say, mistah, we all's gwine to ' $\mathrm{nd}$ lak we cotch all dese fish wid we ali": ish lines.'

"All right, Auntie, I will not give you away," I replied.

She evidently had one of the qualifications of the true angler.

Late in the afternoon I un a lady and a $\&$ itleman coming down the beach in a handsome carriage, drawn by a pair of trin-looking mules. I soon recognized Col. W. N. Haldeman, of the Louisville Courier-Journal, and his good wife. Col. Haldeman was the founder of Naples, where he had a charming winter home. (His sad death through a trolley-car accident will long be regretted and moirned by his many friends.) 


\section{Florida Fish and Fishing}

The Colonel and his lady insisted on my dining with them that evening. I pleaded A Kentucky Welcome that I had nothing to wear but outing clothes, and was not presentable. They would not be refused, however, the Colonel saying that it was their first drive in the carriage, which had been on its way six weeks from Louisville, and that Mrs. Haldeman had honored me by coming herself to invite me. Of course, I had to accept their kind invitation, as I could proffer no more excuses, and especially as the Colonel promised me a real Kentucky dinner; that settled it. We had a delightful drive up the beach on the hard sand at low tide, and the dinner was to the queen's taste: Oyster soum, baked redfish, venison steak, and the Kentucky feature, a roast 'possum with a lemon in its mouth.

After a most enjoyable evening with a happy company, myself and one of my Moonlight Ride by the Sea darkey acquaintances of the morning mounted two saddle mules for a moonlight midnight ride down the beach to the pass. It was a high, spring tide, compelling us to 


\section{Favorice Fish and Fishing}

occasionally abandon the beach where covered with water, and take to the scrub, much to the evident fear of the negro, who, I soon discovered, was very timid and superstitious. He started at every sound in the still night-the puffing of a porpoise in the water or a 'coon or 'possum scurrying through the thick scrub or the weird cry of a night bird caused him to blench with evident fear an ${ }^{2}$ trembling. At the leap of a large fish, a tarpon or jewfish, that struck the water with a resounding splash, he whispered:

"Doctah, was dat a debblefish?"

"It might have bcen," I replied.

Voices of the

Just then a bull alligator in the bayou back of the beach emitted a terrible $r$ followed by the discortant cries of all sor of waterfowl; and, it happened, some large animal, a horse " cow, or perha "a de fled at our af rach and through the scrub. Utengether the ar s) unds were son: What appall ig a culaied to alarm and listres more c geous person. At hat we d the 76 



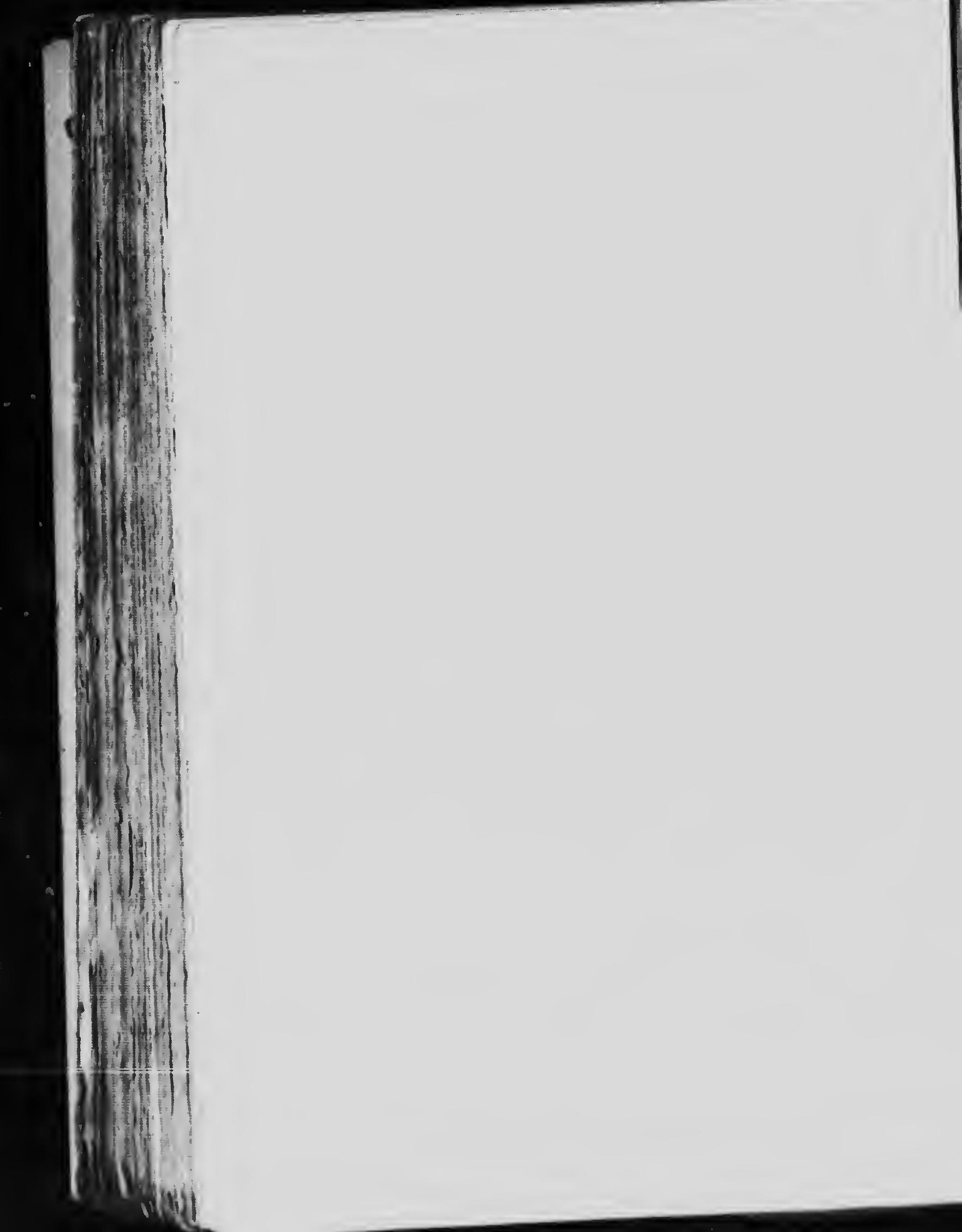


Florida Fish and Fishing

and my boat, with its white canvas roof glaring in the light of the full moon, broke on the gaze of the astonished darkey through the :ees, and as it moved this way and that, responsive to a slight breeze, it seemed an uncanny thin to the thoroughly frightened man as he moaned:

"O Lawd; O Lawd; dar's a spook! De spooks and debble will sho' cotch me. I wish I was Devils back in ole Kaintuck. Oh, doctah, I sho' am 'fraid to go back to-night. I sho' saw de debble's eye shinin' in de bresh, and heard de splash of his tail in de watah, all $d$ : way down. Please, sah, let me stay in de camp till de mawnin'."

I saw that he was really terrified, and that it would never do to let him attempt to return to Naples alone that night. Accordingly we hobbled the mul.s, and I made him a bed in the boat, where he soon was snoring and making as loud and uncouth noises as any "debble" was capable of. In the morning I gave him a good breakfast and started him home with the mules, the happiest coon in Florida. 
Favorite Fish and Fishing

Florida Up to Date
Thave not been in Florida since the winter of $1896-7$, but even then it had greatly changed from the old Florida I knew as far back as 1878 . At the present day my old cruising and camping grounds near Rockledge, Lake Worth and Miami are famous winter resorts, with large and commodious hotels whose luxurious appointments and service are unsurpassed in the world.

Both the Atlantic and Gulf coasts, as well as the interior of the State, are now well-populated by Northern people, mostly engaged in raisir $y$ sub-tropical fruits and early vegetables. Marshy lands, once the resort of innumerable water-fowl, have been drained and cultivated. The pine forests and flat woods where once the cowboy reigned supreme, and where the deer and wild turkey roamed at will, have been decimated or destroyed by sawmills and turpentine stills. The rookeries of the cypress swamps and wooded keys have been laid waste by the plume hunter, so that the flamingo, pink curlew and egret are now but empty sounding names.

178 


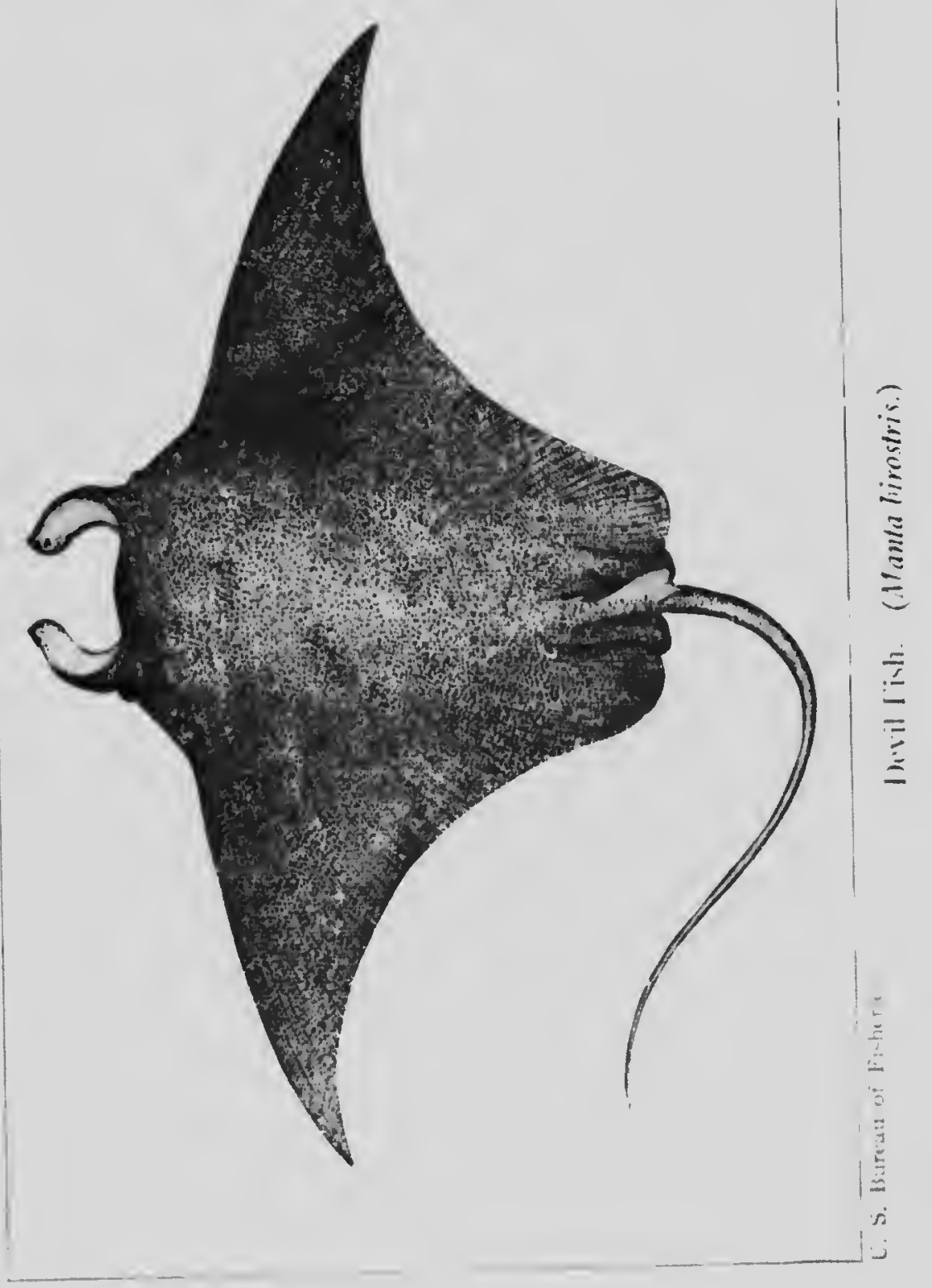



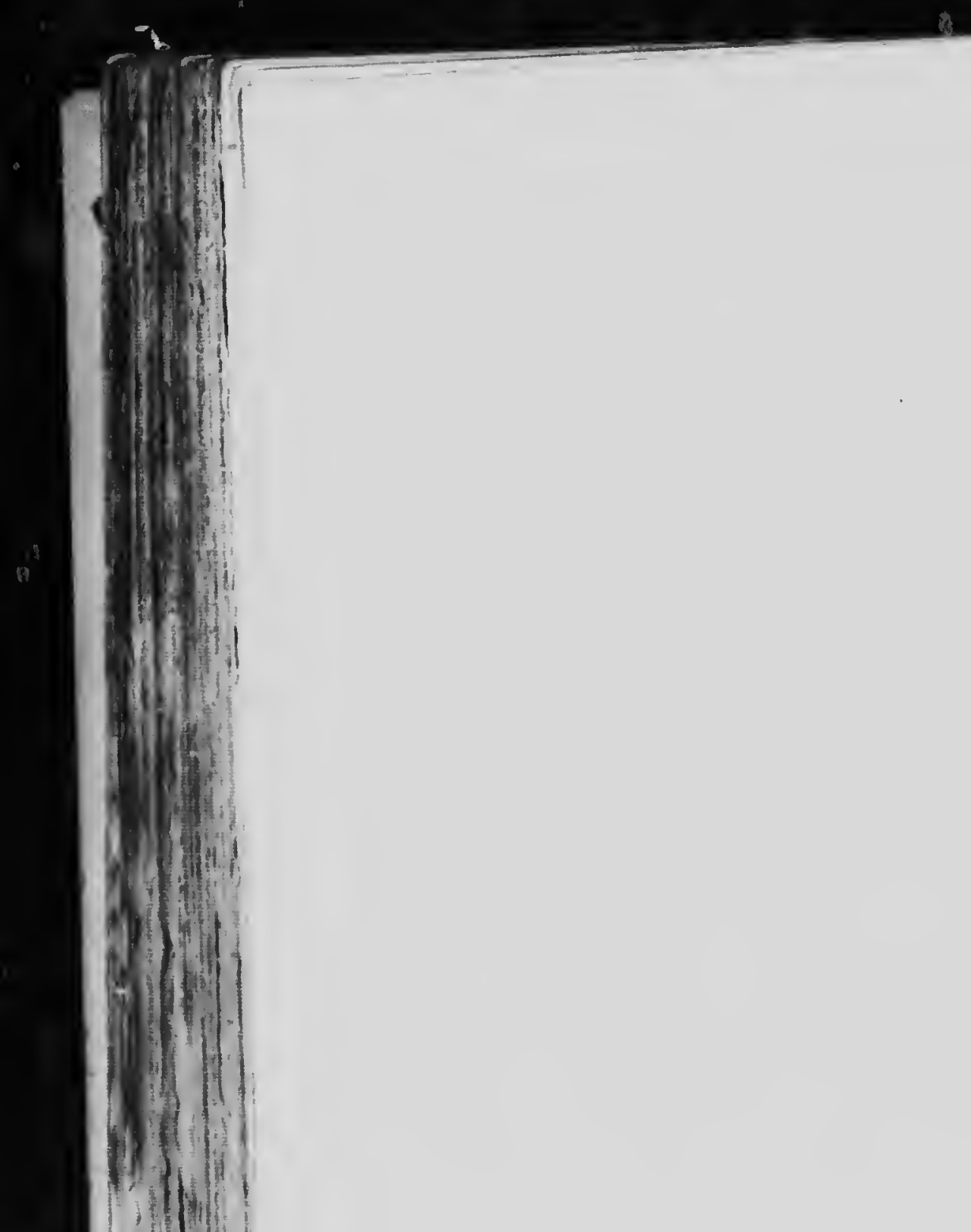

111 His

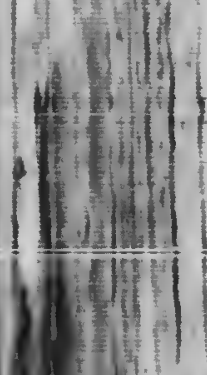




\section{Florida Fish and Fishing}

But while the greed and improvidence of commercial fishermen have greatly reduced the numbers of not only mullet, but redfish, sheepshead, sea-trout and other bay fishes, there still $r$-mains the best and most varied fishing in the world for the angler who cares more for real sport than a big sreel.

In the brackish bays the channel bass, Fishing Galore cavalla, snook, sea-trout, croaker, sailor's choice, etc., will furnish all the sport, either with bait or fly, that the reasonable angler can desire. So, also, at the inlets and passes he may enjoy the matchless sport afforded by the ladyfish and tenpounder. Along the reefs and keys at the end of the peninsula he may troll or cast his lure for the kingfish, Spanish mackerel, amber jack and bonitc. Along the rocky shores the groupers and large snappers will freely respond to his baited hook, while in the channels about the keys those beautiful pan-fish, the grunts, porgies, snappers and other fishes of the coral banks, may be taken ad libitum. 


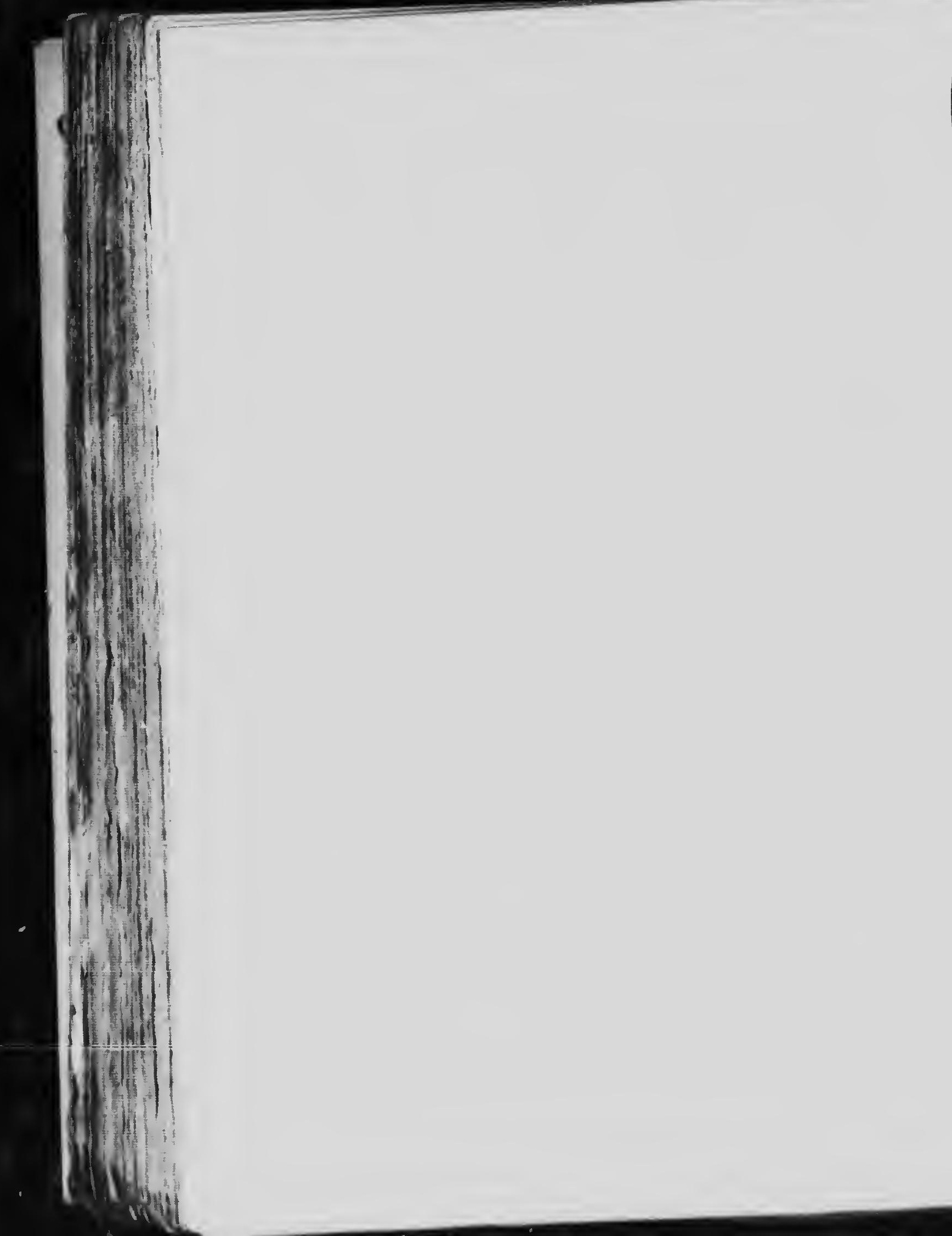



(1)

1 faly

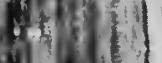

If

1011

(1)

4)

al 1

1)

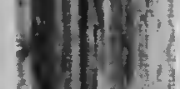

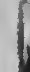

1)

111

A.

A 14

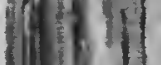

(1) 1

(1)

111

1 II:

i) 1

(2)

(V)

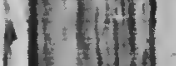

(1) Nor

I IIII)

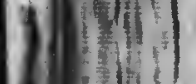

3) 1 I 
INDEX

Absurd names for brown trout, II I.

Anundance of trout, 81.

Ambition, youthful, 7 .

Angler's recital, 8.

Angler's view-point of flies, 76 .

Angling, along east coast of Florida, 168. along Florida Keys, 167.

along west coast of Florida, 169.

charm of, 12.

enthusiasm. for, 5 .

in the lagoons of Florida, 168.

love of, 6 .

parlous times in, 3 .

Arctic grayling, 45 .

Artificial baits, 25.

flies, dark or light, 78 .

flies, for black bass, 24 .

flies, for grayling, 44, 56, 57 .

flies, for trout, 72.

flies, in their season, 77 .

flies, management of, 24, 54, 83 .

flies, philosophy of 74 .

At the yuletide, I4I.

183 


\section{Index}

Baby porpoise, 166 .

Back-log reveries, 66.

Bait fishing, for black bass, 25.

for brook trout, 90.

for Florida fishes, 144, 148, 150, 156.

for grayling, 57 .

for tarpon, 122.

Baits, artificial, 25 .

Barracuda, the, 164 .

Batiscan Falls, 99. river, 95.

Black bass, the, 3 . appearance and habits, 10.

bait fishing, 25 .

breeding habits, 18 .

fishing, 5 .

Hy-fishing, 24.

in new waters, 6 .

in olden time, 9.

leap of, 13.

pond culture, 23 .

propagation of, 22.

season for fishing, 10.

size and weight, 19.

skittering for, 37 .

still-fishing, 38 .

tools and tackle, 26, 27, 30, 31 .

Blue norther, 136.

Bozeman fisheries station, $5 \mathrm{I}$. 
Index

Breeding grow $"$ is of tarpon, I 29.

Brown trout, 110.

absurd names for, 111 .

as a game fish, 111 .

fly-fishing for, I 12.

in Yellowstone Park, I12.

Casting baits, 28.

overhead, 29.

the minnow, 26.

Catching suckers, 159.

Cavalla, the, 145 .

fly-fishing for, 145 .

tools and tackle for, 145 .

Channel bass, the, 149 .

Charms of angling, 12.

Chief function of reels, 32 .

of rods, $7 \mathbf{I}$.

Climate of Florida, 142.

Condition z's. theory about flies, 79.

Cutthroat trout, 102.

Dame Juliana Berners, 43.

Darky and devilfish, 170.

Devilfish, the, 164 .

Distribution of black bass, 20.

of grayling, 49.

Dolly Warden trout, 109.

Dry-fly fishing, 86, 87 .

185 


\section{Index}

Eggs of black bass, 22.

of grayling, 52 .

Ethics of sport, 4 .

Eye of grayling, 48 .

Fair specimen, a, I 38

Fishing reels, 3 I.

$$
\text { rods, } 26 .
$$

Fish story, 91.

Fishes, leap of, I3.

way with a bait, 17 .

Fishing galore, 179 .

Fishing on the verge, 100.

Florida climate, 142.

fish and fishing, $14^{1}$.

grains, 164 .

up to date, 178 .

Flower of fishes, 43 .

Fly-fishing for black bass, 24 .

for cavalla, 146.

for grayling, 54 .

for sea-trout, 148 .

for tarpon, 123.

trout, 82,86 .

Founder of Naples, I74.

Frightened darkeys, I 72.

Gameness of grayling, 45 .

Gav snappers, 151. 
Index

Gilead, balm in, 68 .

Golden trout of Kern River, II 4 .

of Sunapee Lake, II 6.

of Volcano Creek, I I4.

of Sierras, II 3.

Go d haul, a, I 7 I.

Grayling, the, 43 .

Arctic, 45.

as a game-fish, 52 .

distribution, $5 \mathrm{I}$.

fishing, 53.

food and haunts, 49.

Michigan, 46.

Montana, 46.

Propagation, 52.

tools and tackle, 56 .

Groupers and snappers, 150.

Habits of black bass, 18 .

of grayling, 49 .

of tarpon, ! 29.

His Hajes $\psi$, the silver king, I2I.

In olden time, 9.

In old Quebec, 96.

Jack Marrigle, I 53.

Jew fish, the, 158 .

some Jig ones, I 59.

I 87 


\section{Index}

Jewfish, sport with, I 7 I.

Kentucky welcome, 175.

Kingfish, the, 149.

Lacs du Rognon, 97.

Ladyfish, the, I 52.

confusion of name, 154.

differentiation, 155 .

fishing for, 157 .

tools and tackle for, 15 \%.

Leaping of fishes, 13.

Leviathan fishing, 3 .

Love of angling, 6 .

Lowering the tip, 84 .

origin of the ruie for, 85 .

Manatee, the, I6́́.

Mangrove snapper, 151.

Michigan grayling, 46 .

Millions saved, 23.

Minnow, casting the, 26.

Missed opportunity, 103.

Monasteries and grayling, 60.

Montana grayling, 46 .

Moonlight ride by sea, 175.

Mother Nature's sanitarium, 68.

Non-rising of trout, 79. 
Index

Old Kaintuck, 173.

Origin of short casting rod, 27.

Overhead casting, 29.

Parlous times in angling, 3 .

Passing of brook trout, 65.

Michigan grayling, 47,61 .

Peculiar eye of grayling, 48 .

Phosphate fishing, 162.

Philosophy of artificial flies, 74.

Pipe dreams, 67.

Pleasant transition, a, 141 .

Porpoise baby, 166.

calves, 165.

Position of reel on rod, 33 .

Practical hints for trout fishing, 82.

Pride after a fall, 67.

Propagation of black bass, 22.

grayling, $5 \mathrm{I}$.

Pumping tarpon, 127.

Ragtime dude, 151.

Rainbow trout, 107.

in new waters, is 8.

Recital, the angler's, 8.

Redfish, the, $1+9$.

Red snapper, the, 151.

Red-throat trout, 102.

Reels, chief function of, 32 .

189 


\section{Index}

Reel fishing, $3 \mathbf{1}$.

for tarpon, 127.

for trollt, 72 .

on top or underneath, 34 .

position on rod, 33 .

something nore about, 32.

Remora, the, 160.

Restigouche River, 94.

Riband in cap of youth, 8.

Rocky Mountain species, 101.

Rods, fishing, 26, 56, 70, $120,156,170$.

short bait-casting, 27 .

Rovallia, the, 157.

Sanitarium, Nature's, 68.

Scared darkey, 135.

Sea-cow, I66.

Sea-trout (brook), 92.

Sea-trout (Florida), 146.

Sheepshead, the, $1+4$.

Silver king, the, 121.

Silver shuttle, 153.

Skip-jack, 153

Siappers and groupers, 150.

Snook, the, 157.

Something more about reels, 32.

Sorr plight of captain, 136.

Spanish mackerel, the, $1+6$.

Ay-fishing for, 148 . 
Index

Spanish mackerel, shore-fishing for, 147 .

Spearing the jumbos, 163.

Spooks and devils, 177.

Sport, ethics of, 4 .

St. Ambrose and the grayling, 43 .

Steelhead trout, 105.

Stingaree, a, 135.

Strenuous fishing, 165 .

Suckers, catching, 159.

Sunapee trout, 116.

trolling for, 117 .

Sure thing, a, 137 .

Tarpon, the, 121.

enthusiast, 128.

fishing for, 122.

habits of, 129.

in Florida waters, 121.

records, 125 .

the first on a rod, 124.

tussle with a, I 30 .

Ten-pounder, the, 153.

confusion of name, 154 .

differentiation, 155.

fishing for, 157 .

'Tic douloureux, 137.

'Tools and tackle for black bass, 30 .

for brook trout, 70, 91.

for Florida fishing, 169 .

191 


\section{Index}

'Tools and tackle for grayling, 56. fur red-throat trout, 105. for tarpon, 126.

Trout, the angler's pride, 65 . fishing for, $82,86,89$. non-rising of to fly, 79 . tools and tackle, 71 . why it takes the fly, 75 .

Trout's view-point of flies, 76 .

True angler, $d, 174$.

Tussle with a tarpon, 129.

Twin evils, 29.

Vaulting ambition, 14.

Virgin trout stream, 94. Voices of the night, 176.

Wet-fly fishing, 89.

Whipparee, a, 134.

Winninish, the, 93.

Yellowstone Lake trout, 104. Youthful ambition, 7 . 



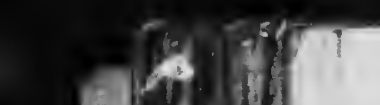





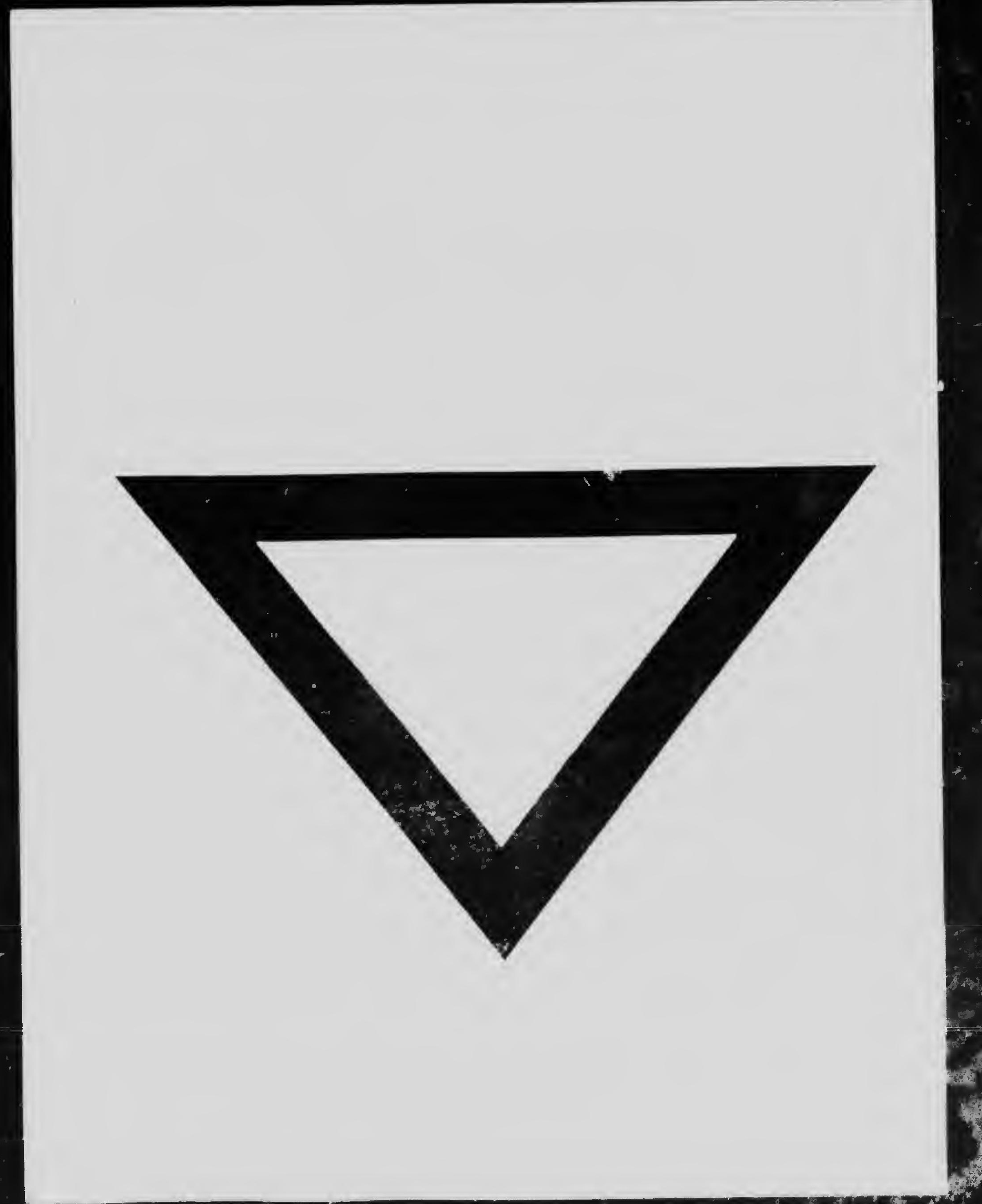

